\title{
ON THE CREATION OF THE GRADUAL OF KING MATTHIAS ${ }^{1}$
}

\begin{abstract}
Although the style of the miniatures in the Gradual of King Matthias has been classified since the beginning as French or Flemish, the origin of the illuminator and of the manuscript itself (whether it was produced in the Netherlands or in Buda) has remained highly disputed. Research carried out by Sandra Hindman and Akiko Komada resulted in the uncovering of a group of works that are more or less closely related to the Gradual. By closely examining the style of these works, I have attempted to revise this group, and to extend it with one new attribution. While the starting point for Hindman - a leaf from the Lehman Collection - has been excluded, there is convincing evidence to support the idea that the Cité de Dieu from Turin and a part of a Bible historiale from New Haven (Beinecke 129), first linked together by Barbara A. Shailor in 1984, were painted by the same hand, namely the Master of the Turin Augustine. With the help of a Book of Hours from the British Library, which shares certain characteristics both with the works of the Master of the Turin Augustine and with the Gradual, it is possible to argue that the Master of the Gradual was probably the apprentice of the Master of the Turin Augustine. Based on codicological, iconographical and stylistic features of these manuscripts, I now put forward some new arguments in support of Komada's proposition, which localises the activity of the Master of the Turin Augustine and the origin of the Master of the Gradual around Tournai or Lille. The Gradual. however, was not produced in the Netherlands. The activity of the illuminator of the Gradual is also attested in Vienna: the frontispiece of an incunabulum from Klosterneuburg, depicting the Stephansdom in the background, was attributed to him by Hinrich Sieveking. This attribution has long served as the basis for arguing that the Gradual was created in Buda, but there is no more evidence for this than for Vienna. On the basis of the script, which - by virtue of its resemblance to the script in a group of Lombard choir books - can be attributed to a Northern Italian scribe, the suggestion that the illuminator may have brought the Gradual with him from the Netherlands can be ruled out. While many questions remained unanswered, it can be concluded that the Gradual of King Matthias was painted either in Buda or in Vienna by a Flemish illuminator, who had presumably received his training in Tournai or in Lille.

Keywords: Corvinian Library, King Matthias, Master of the Turin Augustine, Flemish manuscript painting, manuscript
\end{abstract} production in Buda in the fifteenth century, Northern Italian script, manuscript production in Tournai and Lille

The Gradual of King Matthias is one of the most problematic manuscripts associated with King Matthias I of Hungary (Matthias Corvinus, 1458-1490). ${ }^{2}$ (Fig. 1) Although researchers have repeatedly examined the work for over a hundred years, with a minor monograph - focusing mostly on matters of iconography - published by Erzsébet Soltész in 1980, ${ }^{3}$ and a university dissertation written on it by Júlia Csejdy in 1994, ${ }^{4}$ a number of questions remain unresolved, in particular concerning the circumstances of its

* Eszter Nagy, Institute of Art History, Research Centre for the Humanities, Hungarian Academy of Sciences, Budapest; e-mail: nagykamaraseszter@gmail.com creation (when and where it was made, and the origin of the person - or persons - who made it). Two opinions have crystallised in the literature on the work: the Flemish-style miniatures, which make up the majority of the decoration, are regarded either as French or Flemish imports, or as copies produced in Buda after a Flemish model, although the idea has also been raised that a Flemish illuminator may have been active in Buda. ${ }^{5}$

The idea of a French origin was initially proposed by Elemér Varjú, the first to conduct a deeper examination of the manuscript. In addition to the style of the miniatures, this was implied on the one hand by the blue drapery with 


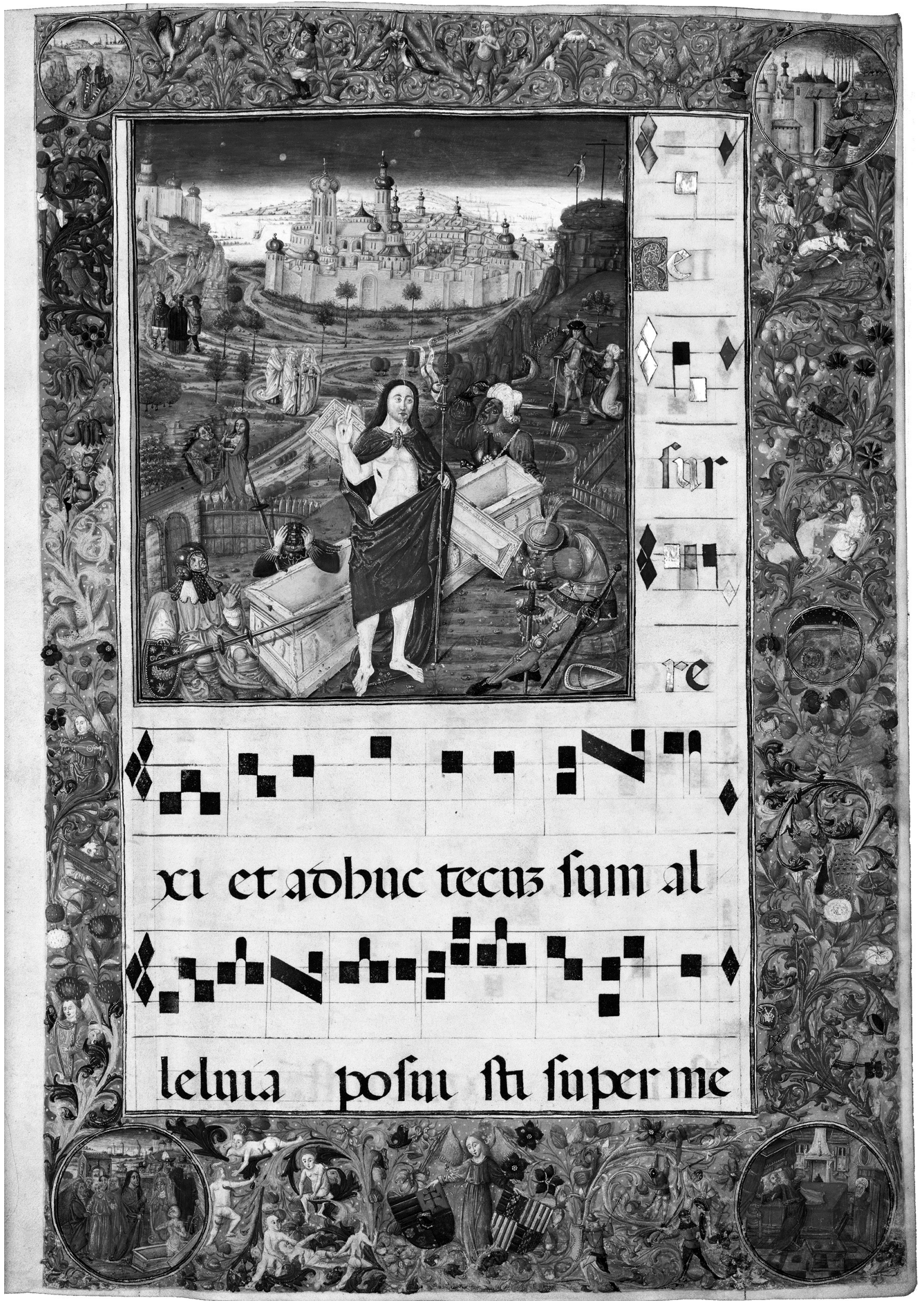

Fig. 1. Frontispiece, Gradual of King Matthias, 1480s;

Budapest, National Széchényi Library, Department of Manuscripts, Cod. lat. 424, fol. 3r 


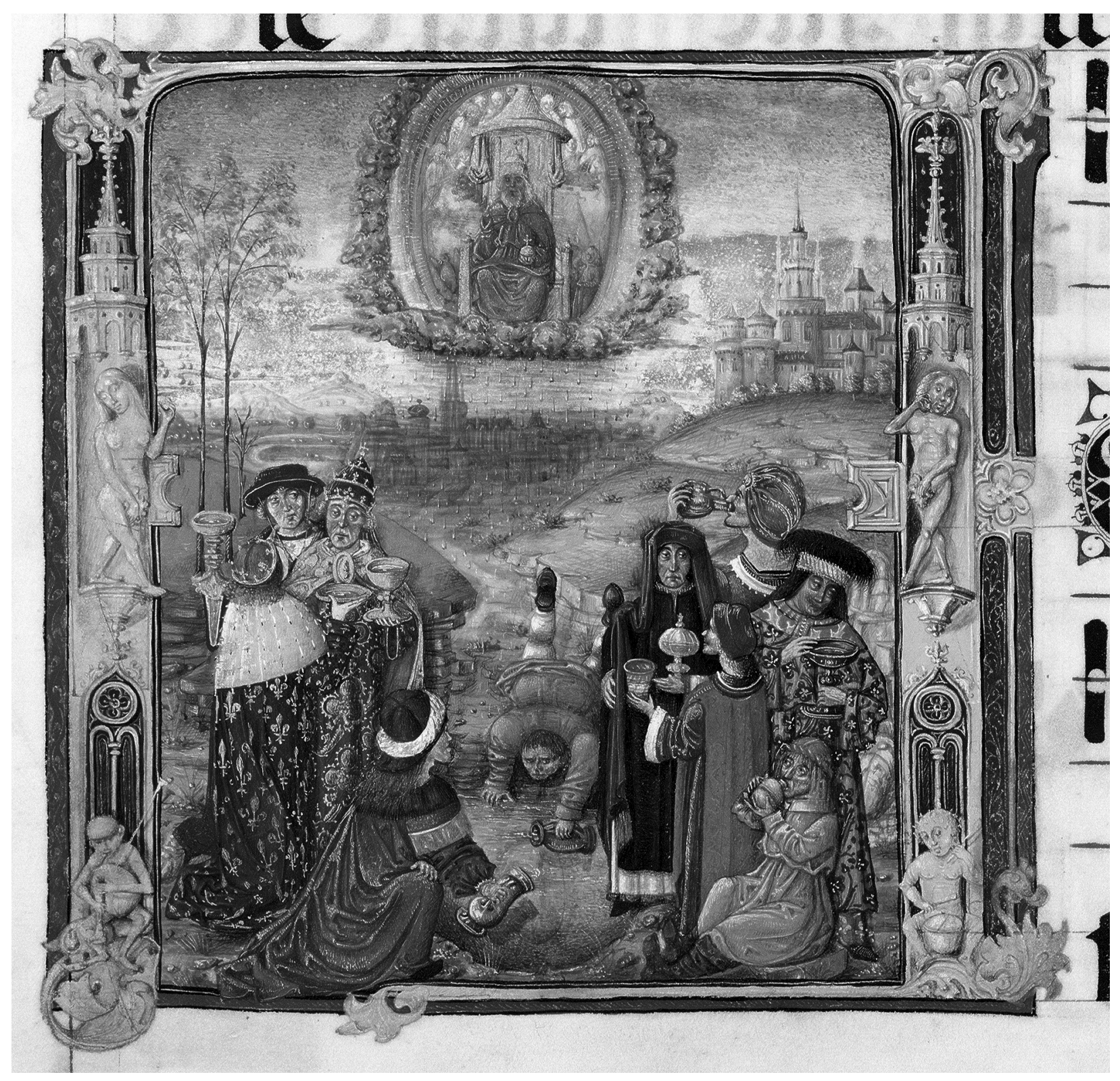

Fig. 2. Initial 'A' / Water of Life, Gradual of King Matthias, 1480s;

Budapest, National Széchényi Library, Department of Manuscripts, Cod. lat. 424, fol. 10r

golden fleurs-de-lis, referring to the French king (Figs. 2-3), and on the other hand by the structural peculiarity, deemed to be a French custom, of the Gradual beginning with the Easter celebrations. ${ }^{6}$ He was also the first to suggest that the manuscript had been received by Matthias as a gift from the French king, ostensibly at the time of the visit to France in 1487 by Matthias's envoy, János (John) Filipec, Bishop of Várad (Oradea, Romania) (1431-1509). ${ }^{7}$ Taking the idea of the envoy's visit of 1487 even further, Ilona Berkovits and later Erzsébet Soltész both argued that the manuscript may have been made in France. ${ }^{8}$ The origin of the illuminator was revised from French to Flemish by André de Hevesy and Jean Porcher. ${ }^{9}$

The possibility that the entire manuscript had been illuminated in Buda was raised by Edith Hoffmann, who regarded the miniatures, by virtue of their poorer quality, as copies of Flemish models actually made in Hungary, and she was joined in this opinion by Hermann Julius Hermann, who referred to its similarity to the Vatican Missal, which was certainly illuminated in Buda. ${ }^{10}$ Kilián Szigeti, who supported the idea of the miniatures being copies, argued that the creation of the Gradual may have had some con- 
nection to Franciscan monks in Hungary, basing this opinion mainly on its script and the manuscript's liturgical peculiarity in following the practice of the Curia Romana. ${ }^{11}$ He first identified it as a gift from Matthias to some Franciscan community, and later, taking into account other liturgical books of Matthias that followed the use of Rome, as a choir book made for the chapel in Buda Castle. ${ }^{12}$ Following Szigeti, Jolán Balogh also defined the manuscript as a work made in Buda after Franco-Flemish models. ${ }^{13}$

A powerful argument in support of Buda as the place of creation, marking a turning point in research into the Gradual, was put forward by Hinrich Sieveking, who, in his 1986 monograph on the Master of the Wolfgang Missal, attributed the frontispiece miniature of an incunabulum in the library of Klosterneuburg Abbey (Cod. Typ. 814; Fig. 29) to the illuminator of the Gradual, and proposed that the illuminator had arrived in Vienna from Buda, as part of King Matthias's entourage, after the occupation of the city in 1485. ${ }^{14}$ Sieveking's proposal was taken up by Franz-Joachim Verspohl in the paper he published in 2000, in which, with reference to Jolán Balogh, he defined the illuminator of the Gradual as a master working in Buda after FrancoFlemish models, and attempted to support this view by identifying details of pictures that refer to King Matthias or Buda. ${ }^{15}$

As a result of Sieveking's attribution, the theory that the Gradual was made in Buda seems

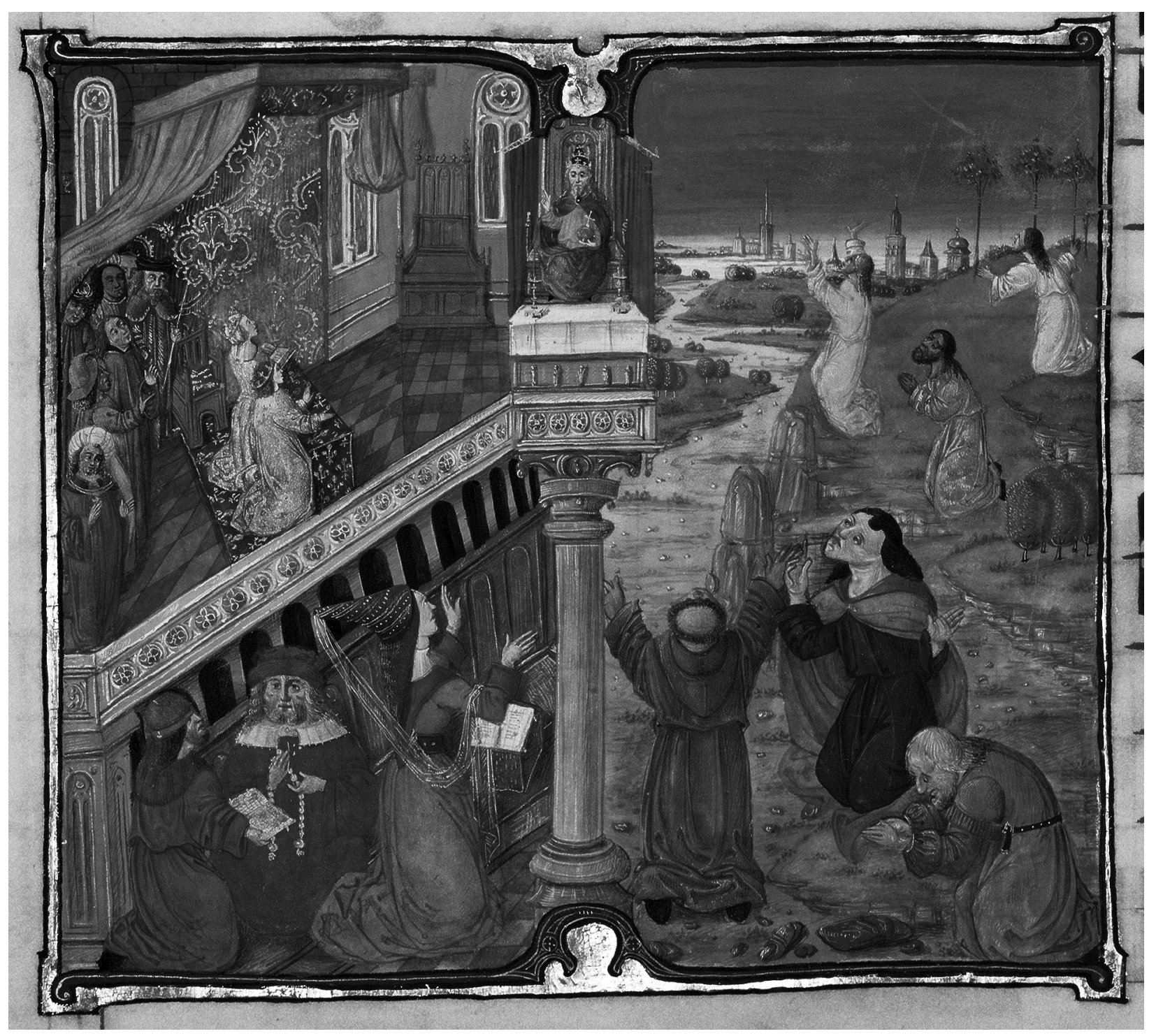

Fig. 3. Initial 'I' / Worship of God, Gradual of King Matthias, 1480s;

Budapest, National Széchényi Library, Department of Manuscripts, Cod. lat. 424, fol. 37r 
to have taken firm root, and there are several recent publications that unquestioningly assert it was made in Buda, ${ }^{16}$ to which in most cases there is an almost automatic connection with the theory, originating from Edith Hoffmann, that the miniatures were copies, or that they at least imitated some now unknown models. ${ }^{17}$ The two ideas, however, are not to any extent mutually linked, so even if it was made in Buda, this does not rule out the possibility that the decoration in the Gradual may have been a work of originality invented by a Flemish master. ${ }^{18}$

This direction is indicated by a few suggestions for attributions that have a bearing on the Gradual that have appeared in recent foreign publications dealing with Flemish manuscript painting, which have so far, it would appear, evaded the attention of researchers in Hungary. One aim of this paper is to take the conclusions from these publications which have not yet been dealt with in connection with the Gradual, and to include them in the discourse on the creation of the Budapest manuscript; the other is to carry out a systematic re-evaluation of previous standpoints and principles, relying also on my own observations.
I begin with an assessment of the attributions proposed by foreign researchers and a detailed analysis of them from a stylistic point of view, followed by localisation of the Flemish illuminator's activity in the Netherlands, with reliance placed on the recommendations made in the literature, together with additional remarks and a new attribution. The paper also, naturally, deals with the Klosterneuburg incunabulum whose frontispiece is associated with the Master of the Gradual, which has hitherto provided the main argument in favour of the Gradual having been made in Buda. A further important aspect of analysis is the script of the codex, which has not been substantially examined since the disputed findings of Kilián Szigeti were published in the 1960s, even though this is a crucial question when trying to uncover the circumstances of the work's creation. The examination of the script also shines a certain amount of new light on the only Northern Italian miniature in the manuscript. The picture that has emerged so far about the Gradual of King Matthias is reconsidered in this paper mostly in terms of stylistic observations, and matters of heraldry and iconography are only touched upon when this is essential in order to obtain a fuller understanding of the problem.

\section{THE FLEMISH ILLUMINATOR}

Among Hungarian researchers, those who sought the illuminator of the Gradual in France or the Netherlands managed to make a few recommendations concerning the master's origins, but apart from a few hesitant attempts to examine questions of style, they were unable to make too much progress. Erzsébet Soltész believed - primarily on the basis of the iconographic similarity between the frontispiece (Fig. 1) and the image of the Resurrection in the Psalter of Jeanne de Laval (1433-1498) - that the manuscript "may have been made in the northern half of France - probably around Angers," which continued with the idea put forward by Ilona Berkovits. ${ }^{19}$ Nevertheless, the composition, which condenses several scenes together, does not establish a solid enough link of commonality on which to base a specific localisation, even taking into consideration the unique iconographic type of Peter emerging from the tomb and meeting the risen Christ. Furthermore, Angers, some $300 \mathrm{~km}$ to the south-west of
Paris, can only loosely be regarded as northern France. ${ }^{20}$

A slightly more precise localisation was attempted in 1994 in the dissertation written by Júlia Csejdy, who, from the starting point of another iconographic similarity, placed the origins of the illuminator of the Gradual to the Utrecht region, and the workshop, or its close environment, of the masters who illuminated the Bible of Evert van Zoudenbalch (1423-1503). ${ }^{21}$ The similarity between the composition of the Last Judgment painted in a Book of Hours kept in Brussels and the miniature on the same theme in the Budapest manuscript (Fig. 4) does indeed provide food for thought. Nevertheless, depictions of the Last Judgment in which the Heavenly Jerusalem is on the iconographical right beneath Christ. and Hell on the left, is not a picture type that was exclusive to the northern part of the Netherlands, for examples can also be found from the southern part, such as Hans Memling's panel painting 


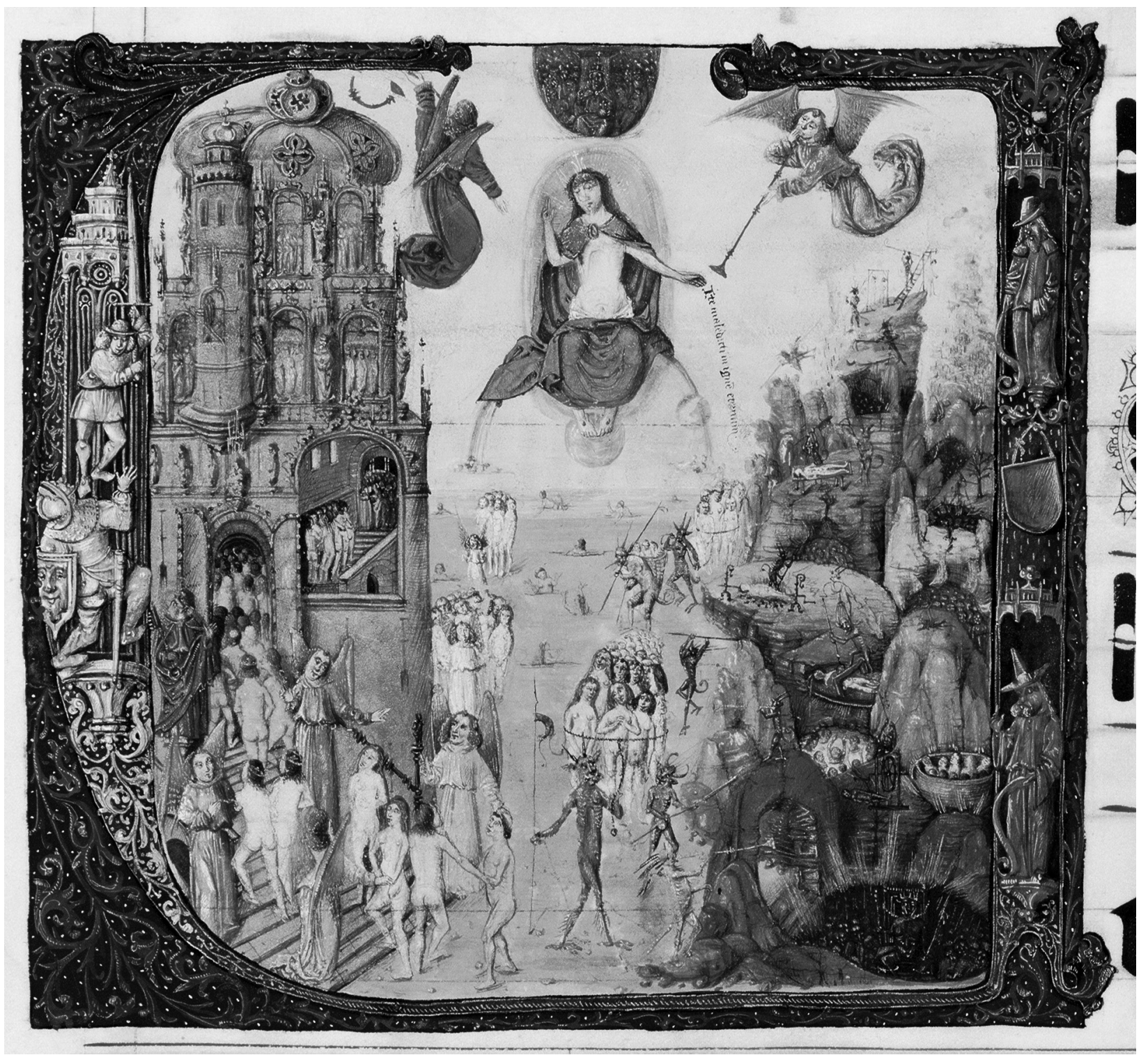

Fig. 4. Initial 'U' / The Last Judgment, Gradual of King Matthias, 1480s;

Budapest, National Széchényi Library, Department of Manuscripts, Cod. lat. 424, fol. $14 \mathrm{r}$

in Gdansk, and in a Book of Hours from Bruges and another of Cambrai or Tournai, both dated to the 1470 s or $1480 \mathrm{~s} .{ }^{22}$

Csejdy's arguments are based not only on iconographic similarity but also on stylistic comparisons, although these appear to be less convincing. The perspective in the rooms made by the illuminator of Utrecht is more determined than that in the interiors of the Gradual, and instead of the conical cliffs with drawn demarcations that are so typical of the master of the choir book, the landscapes are characterised by formations that combine grassy slopes with steep, layered, craggy surfaces that are modelled with patches of colour. The faces are also of different types. This is particularly obvious in the case of more misshapen, grotesque figures. The master of the Bible of Evert van Zoudenbalch produced more rounded clean-shaven faces, with rather globe-shaped skulls, and often retroussé noses, while there is a complete absence of figures fixed in caricature-like poses, with pointed chins, and heads protruding further forwards above their shoulders, which are characteristic of the Gradual. $^{23}$ (Figs. 3, 32)

Foreign research that took a greater overview of Flemish manuscripts has never focused on the Gradual, but through examinations of other works, a group of related manuscripts has come about which may be used to make a more accu- 
rate localisation of the origins of the illuminator. First of all, Sandra Hindman, in the catalogue of the manuscripts and illuminated pages in the collection of Robert Lehman of 1997, proposed noteworthy stylistic relationships for the Gradual of King Matthias. ${ }^{24}$ A miniature depicting Christ's entry into Jerusalem, cut out of an evangeliary and now in the Lehman collection (Fig. 19), was connected by Hindman with two further leafs which, in her opinion, originated from the same book, ${ }^{25}$ and with two additional manuscripts in addition to the Budapest Gradual: the Bible historiale in the Beinecke Library in New Haven (ms. 129) ${ }^{26}$ and a two-volume Cité de Dieu manuscript now kept in Turin (vol. 1, BNU L I 6 and vol. 2, AST Jb. III. 1227). The latter two manuscripts were already attributed to the same master in 1984 by Barbara A. Shailor, relying on the information provided by James Marrow and Anne van Buren. ${ }^{28}$ The group that was thus formed was classified under the conventional name of the "Master of the Turin Augustine," ${ }^{29}$ although the stylistic homogeneity is not of a sufficiently high degree to warrant regarding these manuscripts as all the work of a single master. Determining the closer or looser connections among them, and evaluating possible further attributions, will require more detailed stylistic analysis, which has only partially been carried out by researchers so far.

\section{The Master of the Turin Augustine}

The core of the group attributed to the Master of the Turin Augustine consists, not only in terms of the history of research, but also in terms of style, of the manuscripts in Turin and New Haven. It is therefore worthwhile first examining the connections they have with each other and with the Gradual of King Matthias.

Similarities may be observed among the miniatures of the Cité de Dieu and the Bible historiale in the formation of the landscapes that serve as the setting or background to the majority of scenes. Beneath a raised horizon, a strongly divided, varied landscape emerges with clumps of trees, roads, rivers and cliffs, but they do not converge into a realistic, coherent space - this is also prevented in several places by the inconsistent alterations in the sizes of the trees (e.g. Bei- necke 129, vol. 2, 142r) -, and there is often no integration between different parts of the scenery. The figures are also inserted disjointedly into the landscape, and the scenes are often crowded into the foreground, which is commonly crowded with tufts of grass and stones. The lack of assurance in handling space is even more striking in the case of buildings and interiors, which are rich in varied detail, but pay no heed to the rules of perspective, with different spaces, internal and external, connected together clumsily. This is evident in the scene of the Presentation of Samuel in the Bible historiale, where the ogee arch above the diagonally placed steps has been drawn faceon (Fig. 5), while a similar anomaly between a throne and its baldachin can also be seen in one of the illustrations in the Cité de Dieu. (Fig. 6)

The relationship between the Turin and New Haven manuscripts and the Gradual is most apparent in these respects. The architectural constructions in the choir book are also intricate, complex and imaginative, and the master has paid even greater attention to detail, but the rules of perspective are still completely ignored, the connections between different parts of the buildings and different spaces are still haphazard, and the transitions between inside and outside are often quite indistinct. It is enough simply to compare the cities and chateaus of the Gradual (Figs. 1, 9, 11), and its interiors (Figs. 3, 7), with the buildings visible on fol. 239r of the first volume and fol. 208r of the second volume of the Cité de Dieu (Figs. 8, 10), with the scene of the Presentation of Samuel in the Bible historiale (Fig. 5), and with the view of Jerusalem in the background of the miniature depicting Jeremiah deep in thought (vol. 2, fol. 285v). Even the relatively simple block shapes of objects as altars, tables and benches are inexpertly formed, with the illustrator using inverse perspective in several places (BNU L I 6, fol. 293v [Fig. 6]; OSZK Cod. lat. 424 , fols. $127 \mathrm{v}, 197 \mathrm{r}$ ).

A similarity is also discernible in the formation of the scenery, which is still strongly divided due to the diversity and multiplicity of the strange, conical cliff formations, mountains, roads, rivers and trees. While the winding rivers and roads often lead the viewer's eye deep into the pictorial space, linking the different layers of space together, the confused muddle of landscape elements remains prominent, and in most 


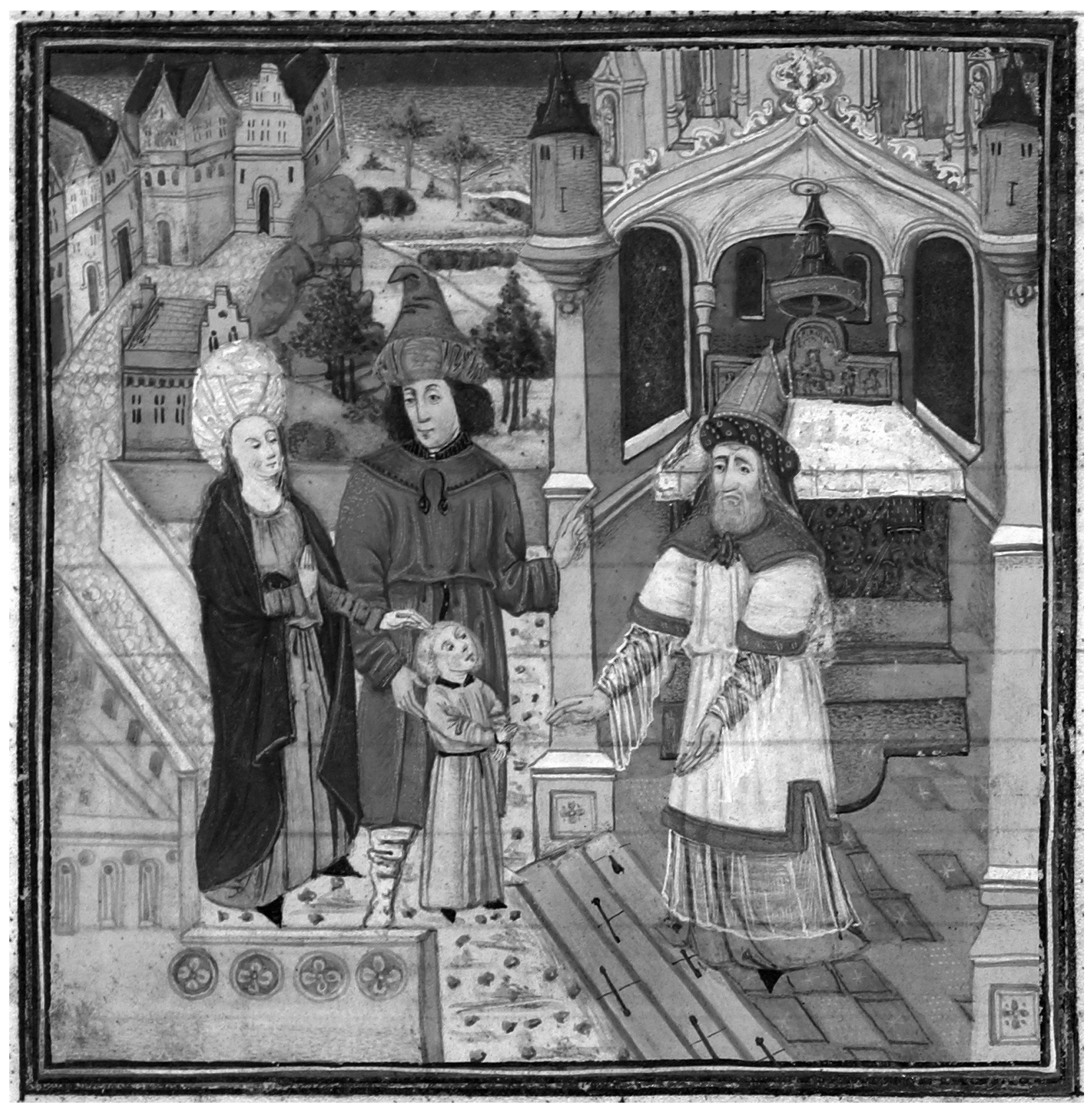

Fig. 5. Presentation of Samuel in the Temple, Petrus Comestor: Bible historiale, 1465-1470; New Haven, Beinecke Rare Book and Manuscript Library, Yale University, ms. 129, vol. 1, fol. 196r

cases there is no sense of spatial unity, not even in the Gradual. Undoubtedly, in the Budapest choir book, all these elements are presented in greater detail and variety, and are more carefully executed. In the other two manuscripts, the atmospheric effects (such as rain), the clouds and the heavenly phenomena are not conveyed with the same refinement of rich colour that makes certain miniatures in the Gradual (fols. 10r, 17v, 45r and 90r; Figs. 2, 30) so appealing. A certain amount of progress can also be detected in the miniatures of the Gradual with regard to the relationship between the figures and the space they occupy, with some figures now also appearing in the mid-ground as well as the foreground. Nevertheless, they are rarely integrally incorporated into the landscape, and the scenes seem to be played out one on top of the other, rather than one behind the other. The figures are often disproportionate to their environment, and they do not always diminish consistently in size the further away they are portrayed (e.g. the soldiers 
in the background of fol. 95r are the same size as the figures in the mid-ground; [Fig. 11]). The spatial relationship between the figures is also sometimes confusing: the kneeling monk on fol. $37 \mathrm{r}$ seems to be further forward than the figure in blue, yet his raised arm half covers the palm of the person in blue. (Fig. 3)

With regard to the figures and physiognomic types, there are several close points of similarity between the Turin and the New Haven manuscripts. In the case of young, clean-shaven men shown in three-quarter profile, in both manuscripts they typically have slightly extended heads, long, straight noses connected to arched eyebrows, straight upper lips paired with thicker (in several places, dot-like) lower lips, and tufts of hair protruding on both sides. The physiognomies of the young men in two scenes in the Bible historiale (Presentation of Samuel and Death of Tobias) are therefore remarkably close in appearance to Romulus and to the figure brandishing a broken lance from the Turin manuscript. (Fig. 12) A further close similarity can be seen in the oval faces of the angels, with the curving line of the forehead and hair, the rich mass of hair on the sides, and the upright, flame-like locks of hair at the middle of the forehead. (Figs. 27, 28) The female figures are also closely related: the face of Judith in the Bible historiale and those of Saints Catherine and Barbara in the Cité de Dieu are representatives of the very same type. (Fig. 13)

When comparing the figures in the Turin and New Haven manuscripts with those in the Gradual, although similarities can be found, they are not so closely matched as those described in the preceding paragraph. The former do not have the same distinctive figures stiffened into grotesque poses, that are found in the choir book, whose heads are pushed further forward from their shoulders, with stooped backs, and chins raised, sometimes at right angles. Although this posture often appears in situations that demand that the figures pray or look up to the sky, the illuminator also portrayed figures in this way in other contexts as well, where there seems to be no justification for doing so: examples are the goldsmith and soldier of fol. 103r (Fig. 32), the figures in the procession on fol. $69 \mathrm{v}$, and the knight in golden armour on fol. 95r. (Fig. 11) There is also significant dissimilarity between the neckless figures of the Bible historiale, with their large, bulbous noses and their heads sunk close to their shoulders, and the figures in the Gradual with their protruding necks and their thinner, smaller noses. ${ }^{30}$

The secondary decoration brings the threads connecting the Cité de Dieu and the Bible historiale even closer: several miniatures in the Cité de Dieu and the scenes from Genesis in the New Haven manuscript are framed by very similar gold tendrils on a red base. ${ }^{31}$ (Figs. 6, 8, 17) By contrast, the secondary decoration of the Gradual bears no relationship with the two earlier manuscripts: in those there is no trace of the ornamentation of the large initials in the Gradual, nor of the frontispiece's illusionistic marginal decoration. It must be noted, however, that the bordures in the Turin manuscript also differ from those in the New Haven volumes. The stout, densely dentate acanthuses of the latter are completely different from the ribbon-thin, barely toothed leaves in the Cité de Dieu. (Fig. 14) Details that would enable a comparison of the large initials are incidentally absent from the latter manuscripts. This does not necessarily imply, however, that the master who painted the miniatures was not the same person, for the task of decorating the margins was often allocated to a different illuminator from the person making the illustrations. ${ }^{32}$

When evaluating and interpreting the differences and similarities between the Gradual, on the one hand, and the Turin and New Haven manuscripts on the other, two further factors must be borne in mind: the stylistic differences within each individual manuscript, and the dating of the manuscripts in comparison with each other. The Flemish cycle in the Gradual has been regarded repeatedly by different scholars as the work of more than one illuminator. ${ }^{33}$ The untenability of this argument from both the stylistic and practical points of view is discussed later in this paper, once we are in possession of the lessons that can be deduced from a more precise localisation of where the Gradual was made. The decoration of the Cité de Dieu seems to be uniform, and can be attributed to a single master. By contrast, the miniatures of the Bible historiale appear remarkably heterogeneous: Shailor distinguished between two illuminators, the master and his assistant, assigning the first volume to the former and the second to the latter. ${ }^{34}$ Komada identified the differences at the level of the ornamental decoration, 


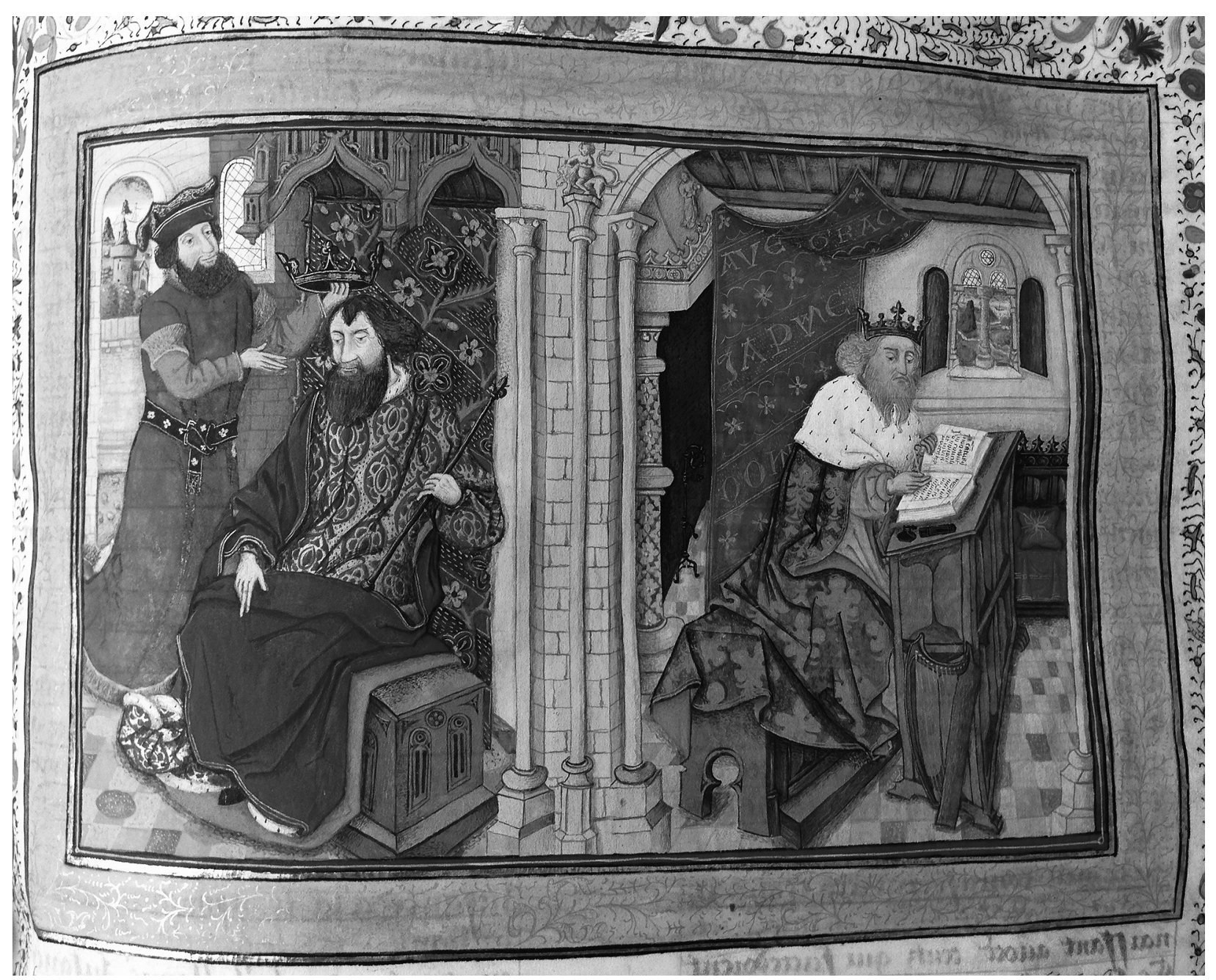

Fig. 6. Samuel, Saul and King David, Saint Augustine: Cité de Dieu, vol. 2, c. 1466; Turin, Archivio di Stato di Torino, ms. Jb. III. 12, fol. $174 \mathrm{r}$

and indeed, the bordures in the two volumes deviate not only in the fact that in the first volume, the miniatures are separated from the margin by a thin bar that protrudes from the initial, but also in the shapes of the details. ${ }^{35}$ Whereas the first volume features twisting, fleshy acanthuses with dense dentation picked out in dark blue and gold, in the second volume they are thinner, the leaves are rarer and more casually scalloped, and in addition to a lighter blue and gold, there are also additions in pink and green. (Fig. 14)

Stylistic differences can also be detected in the miniatures, but these seem, to me at least, not to be separable according to each volume. In the first volume, the scenes of Joseph Sold by his Brothers (Fig. 15), Moses and the Israelites (fol. 63r) and the Execution of a Soldier (fol. 217v) are closely related. They are linked by the rounded faces, the thick, broad lower lips, the regularly arranged lines that suggest locks of hair, the drapery, modelled with parallel diagonal lines, and - in the case of the latter two illustrations - the more robust buildings in the background. The medallion of The Creation of Eve (Fig. 17) can also be classified with this group. The miniature depicting the Presentation of Samuel (Fig. 5) is less closely related, in terms of figural style, as are the figures in the Sacrificial Scene (fol. 101r): the faces are more extended, there are no lines indicating locks of hair, the figures' upper lips, drawn from a single line, are paired with smaller, dot-like lower lips, and the drapery is also handled differently. These miniatures bear a much closer resemblance to certain scenes in the second volume: the Death of Tobias (Fig. 16), the Birth of Saint John the Baptist (fol. 153v), and Saint John Drinking from the Poisoned Chalice (fol. 289v). Moreover, the connection between the 
other miniatures in the two volumes is close: the same chubby faces, for example, can be picked out of the crowds in the scenes of Moses with the Ten Commandments (vol. 1, 142v) and Esther before Ahasuerus (vol. 2, 84v). The different marginal decoration and the slightly more negligent execution of the second volume may indeed be explained by the collaboration of an assistant, who made serious attempts to come close to the miniatures in the first volume, although the differences in quality may also be ascribed to greater haste. At the same time, the stylistic differences outlined above provide further justification for inferring that two hands were at work in the first volume. Of the two, the one who painted, among other scenes, the Presentation of Samuel (Fig. 5), appears to be identical to the master of the Turin Cité de Dieu. The difference between the illuminator of the Turin manuscript and the other hand are most apparent in the scenes of The Creation of Eve. (Figs. 17-18) In the latter, the figures of Adam and Eve deviate from the figures in the Turin manuscript not only with their rounded, short-nosed faces, but also in the way their naked bodies are formed: in the Bible historiale the skin colour is more brownish, the modelling is more distinct, and Eve's significantly protruding belly is absent from the Turin manuscript.

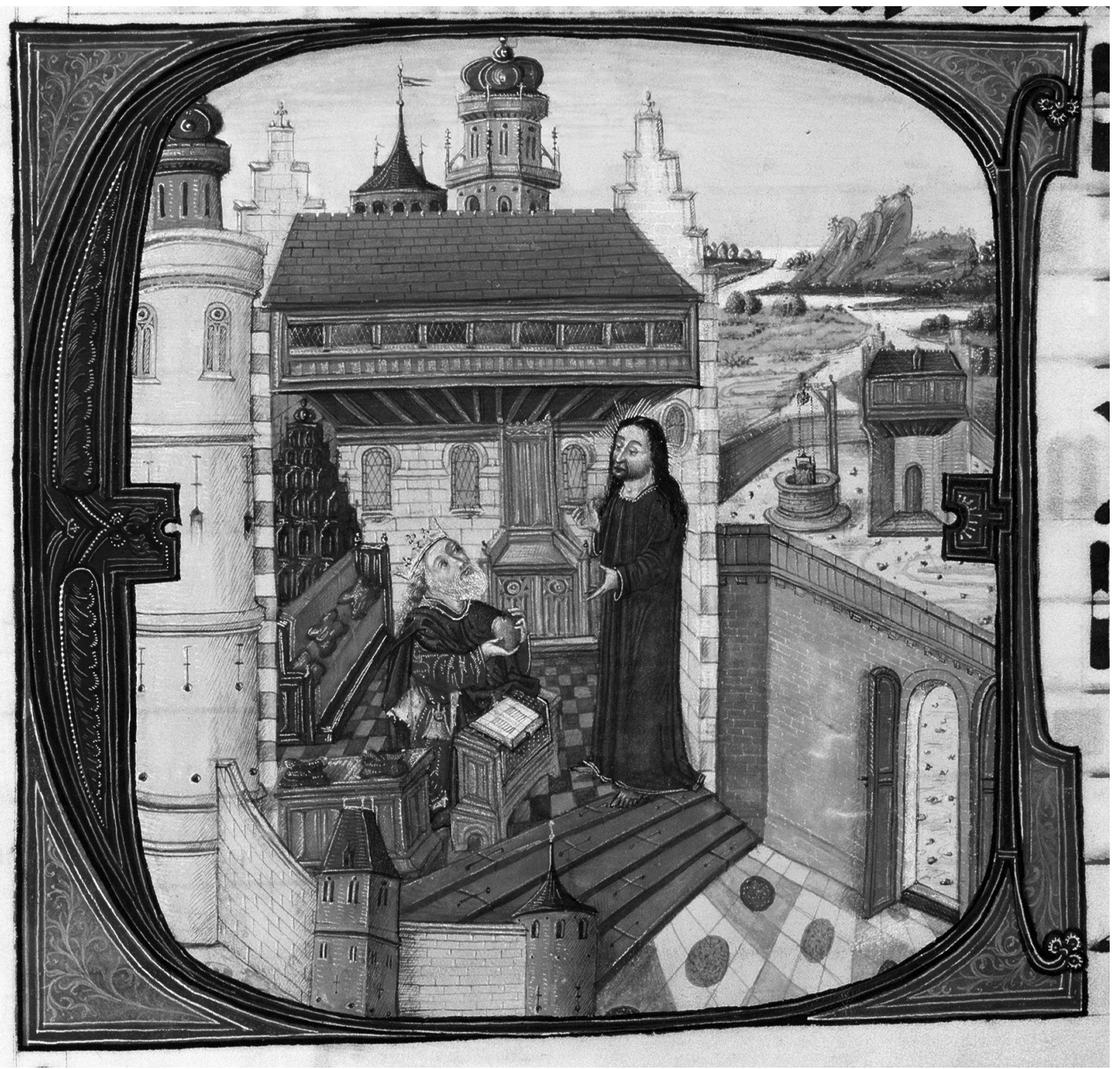

Fig. 7. Initial 'E' / King David Praving to Christ, Gradual of King Matthias, 1480s; Budapest, National Széchényi Library, Department of Manuscripts, Cod. lat. 424, fol. 58r 
To move on to the dating of the manuscripts, by virtue of the joint coat of arms of King Matthias and Queen Beatrice of Aragon that appears on the frontispiece, the Gradual is dated to later than 1476 , usually to sometime in the $1480 \mathrm{~s} .{ }^{36}$ The copying of the manuscript of Saint Augustine in Turin was completed, according to the $\mathrm{col}$ ophons, by the scribe Jean du Quesne in 1466 , and the decoration can therefore be estimated to 1466-1467. ${ }^{37}$ Based on the close stylistic similarity, Akiko Komada has dated the Bible historiale to approximately the same period, around 1465-1470. In Komada's view, another Bible historiale, manuscript 312 in the Bibliothèque Mazarine, Paris, provides a starting point for the date, partly because its content and text are so similar to the New Haven manuscript that it was presumably copied from the Paris manuscript, and partly because the two copies are so obviously similar in their iconography that the Mazarine 312 must have served as a direct model for the Beinecke manusript. ${ }^{38}$ Komada therefore places the terminus ante quem for the New Haven Bible historiale at 1469 , which is when the erstwhile owner of Mazarine 312, Antoine de Crèvecoeur, a nobleman from Artois, entered the service of the King of France, because after this date, the model would no longer have been accessible in the Netherlands. ${ }^{39}$ This argument, however, can only be accepted with certain reservations, because there is no evidence that proves the book was moved from the Netherlands at that time. Despite the uncertainties surrounding dating, it can be stated that the Gradual was made at least

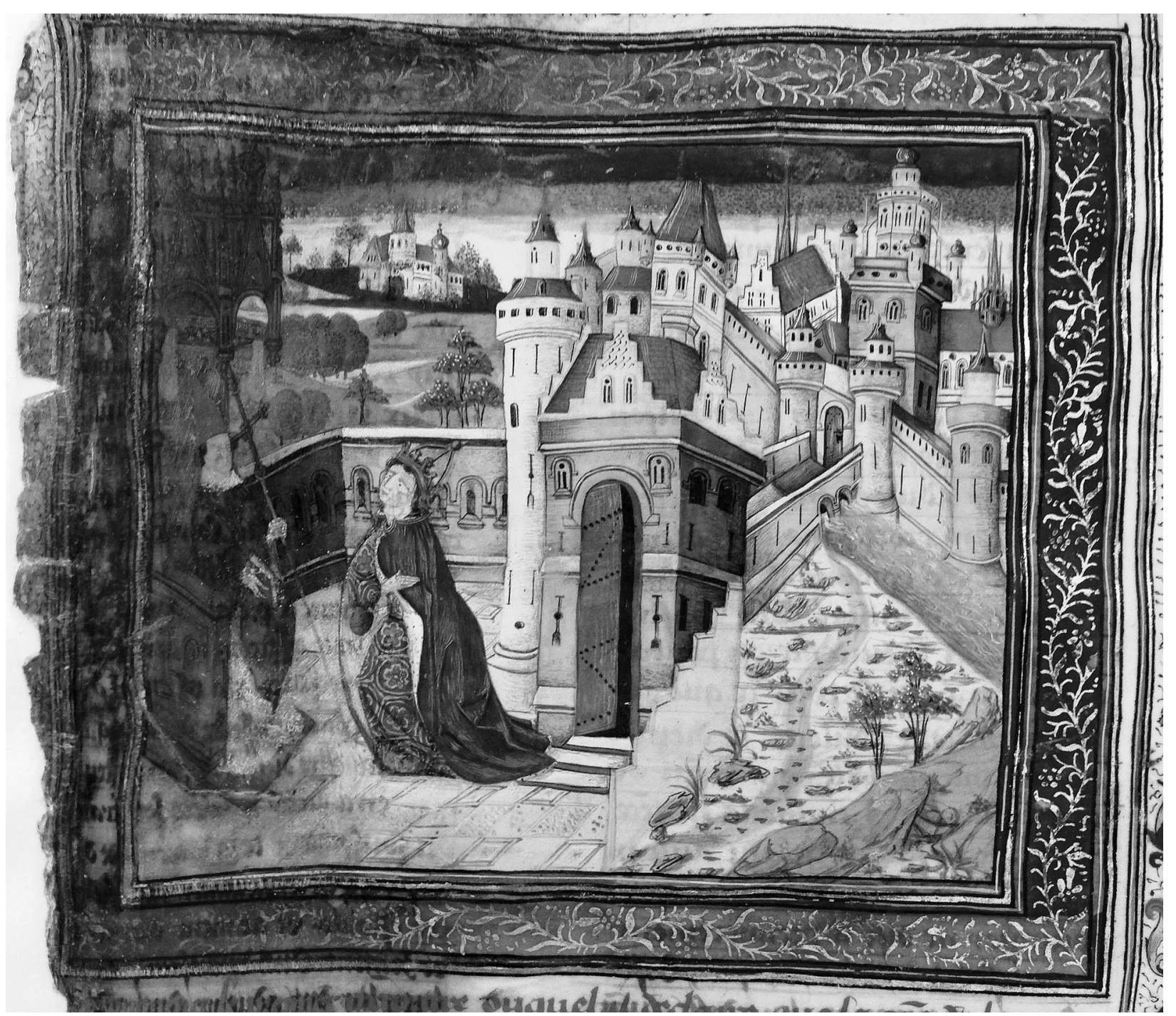

Fig. 8. Pope and Emperor, Saint Augustine: Cité de Dieu, vol. 1, c. 1466;

Turin, Biblioteca Nazionale Universitaria di Torino, ms. L I 6, fol. 239r 


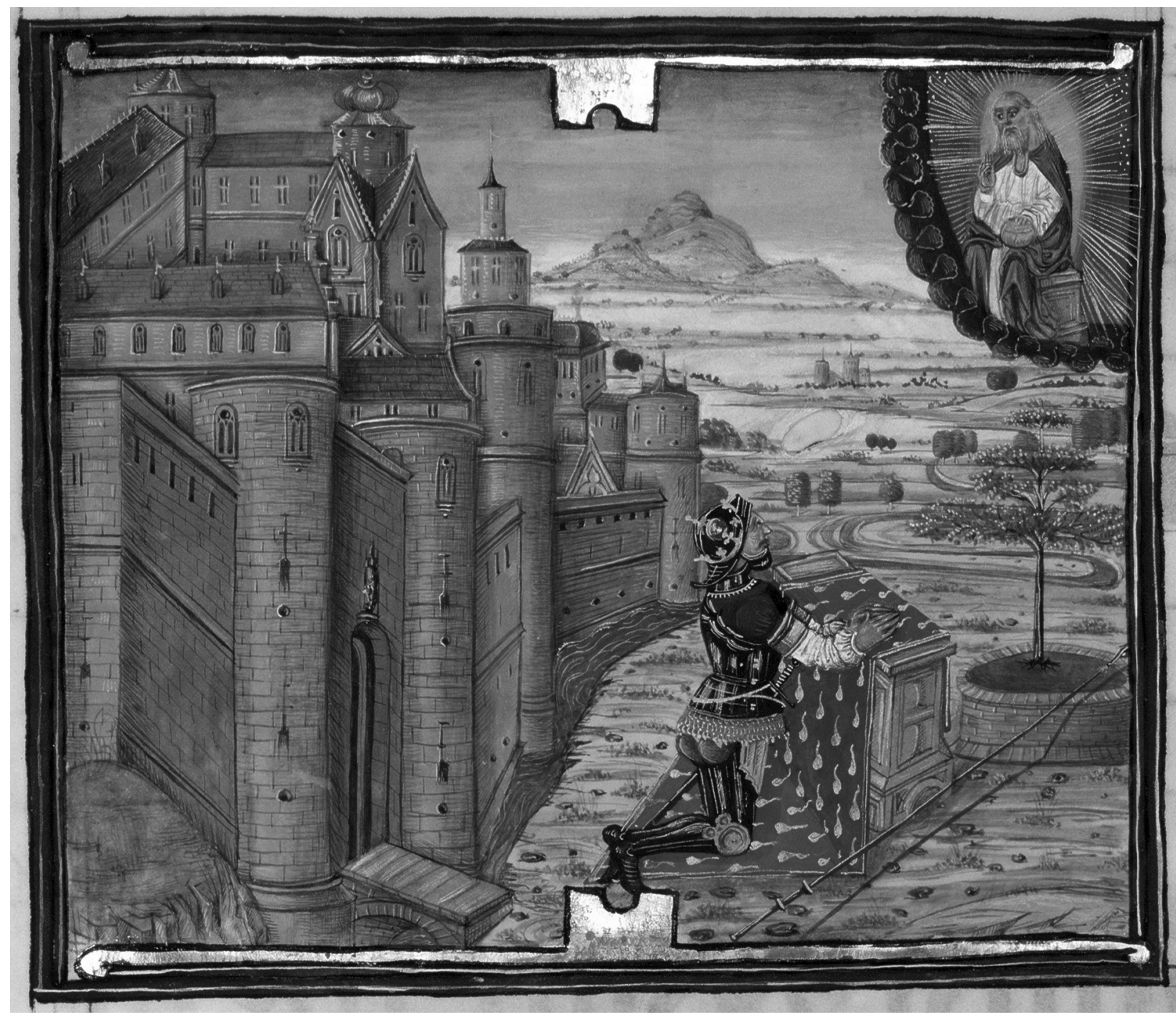

Fig. 9. King David Praving. Gradual of King Matthias, 1480s:

Budapest, National Széchényi Library, Department of Manuscripts, Cod. lat. 424, fol. 149r

one decade, and up to two decades, later than the other two manuscripts.

Such a long intervening timespan would certainly explain the change in style, but I am of the view that, even taking this interval into account, there is no significant similarity between the Gradual and the two earlier manuscripts to justify attributing them to the same hand. The possibility of the illuminators sharing a workshop, however, or of a master-pupil relationship between them, as proposed by Komada, is worth further investigation. ${ }^{40}$ It would only be possible to formulate a firmer position if the group of manuscripts could be demonstrably expanded with further illustrated manuscripts which, both stylistically and temporally, would span a bridge between the Cité de Dieu and the Bible historiale, on the one side, and the Gradual of King Matthias, on the other, and whose differences could be explained by a working relationship or a master-pupil connection. In addition to the manuscripts already discussed, a number of others have also been connected to the Master of the Turin Augustine, but none of them act as this bridge, and moreover the attributions seem to be insufficiently grounded.

In terms of date, the other work closest to the Gradual is Hindman's suggestion of the New York leaf of the Entry into Jerusalem, which was probably painted in the $1480 \mathrm{~s}$, judging from the illusionistic border. ${ }^{41}$ (Fig. 19) In addition, the approximate equal size $\mathrm{e}^{42}$ and the care with which it was produced would seem to suggest a close relationship with the Budapest manuscript, 


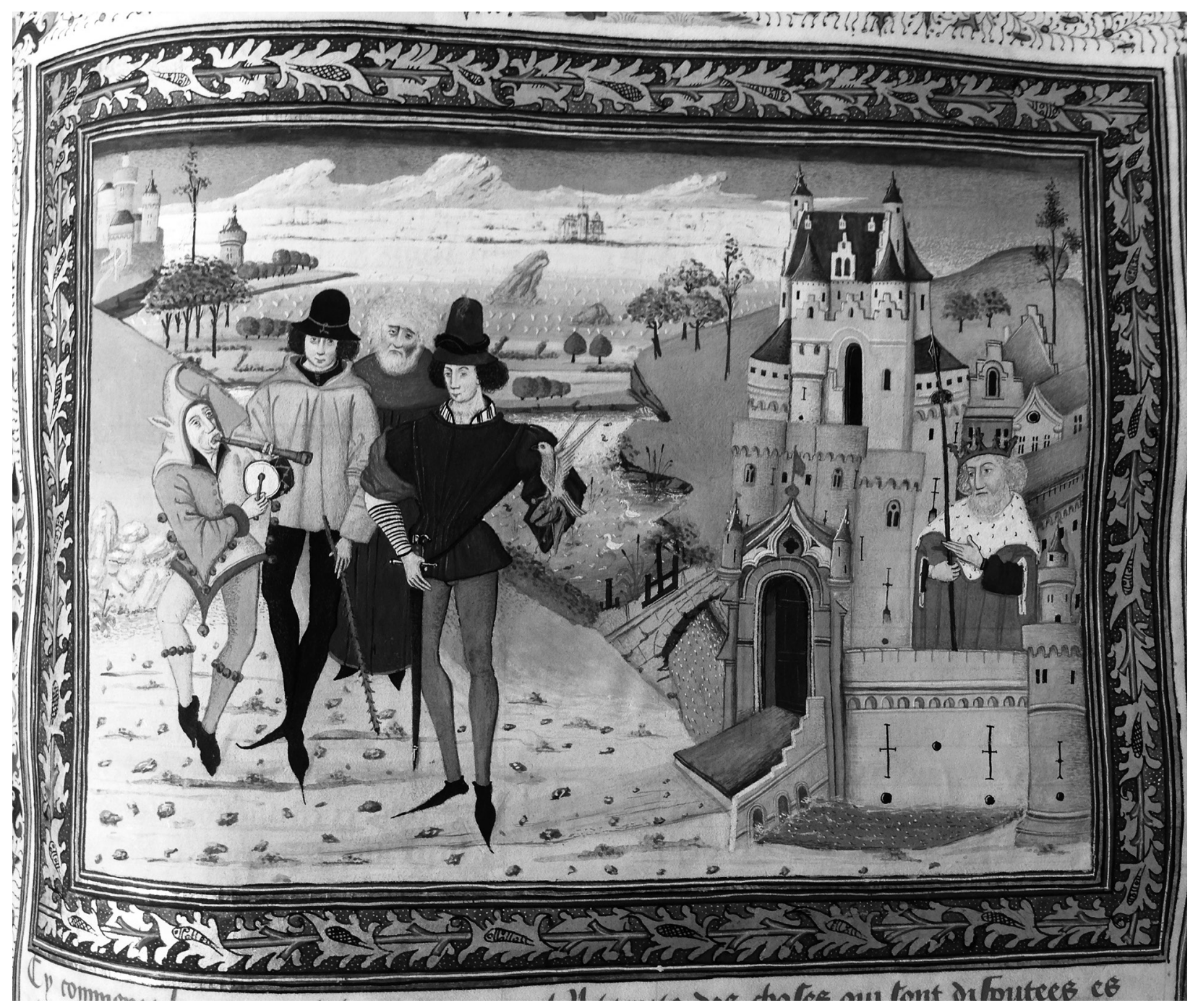

Fig. 10. Romulus and Remus, Saint Augustine: Cité de Dieu, vol. 2, c. 1466; Turin, Archivio di Stato di Torino, ms. Jb. III. 12, fol. 208r

but this is not reinforced by a general impression, nor by a detailed comparison. It is also difficult to compare the Entry into Jerusalem miniature with the Cité de Dieu and the Bible historiale. Unlike the Master of the Gradual, the illuminator of the New York leaf created a coherent space, in which the figures become proportionately smaller with distance. Their spatial integration is further enhanced by the relatively consistent use of cast shadows. Compared with the varied and divided landscape backgrounds in the Budapest manuscript, the scenery on the New York leaf is much more cogent and more monumental, and seems more like a real environment. The perspective view of Jerusalem, with its complex conglomeration of buildings, is also executed with greater skill by the illuminator of the New York leaf. In brief, then, the features that were relied upon as similarities between the choir book and the two earlier manuscripts are the very same features that exhibit the vastest differences between the Gradual and the New York leaf.

The striking qualitative differences in the overall picture are not counterbalanced by a comparison of the details. The long, narrow type of face with hair combed over the forehead, as exemplified by the kneeling figure, by the disciple on the right edge, and (apart from the hair) by the figure of Christ, is not at all similar to the figures in the Gradual; nor are the straight eyebrows, thickening slightly around the nose, that can be seen on the Entry into Jerusalem. Likewise, there is no echo in the miniature from the Lehman Collection of the distinctive forwardjutting, sometimes triangular heads seen in the choir book, with their dot-like, thick, bright red 


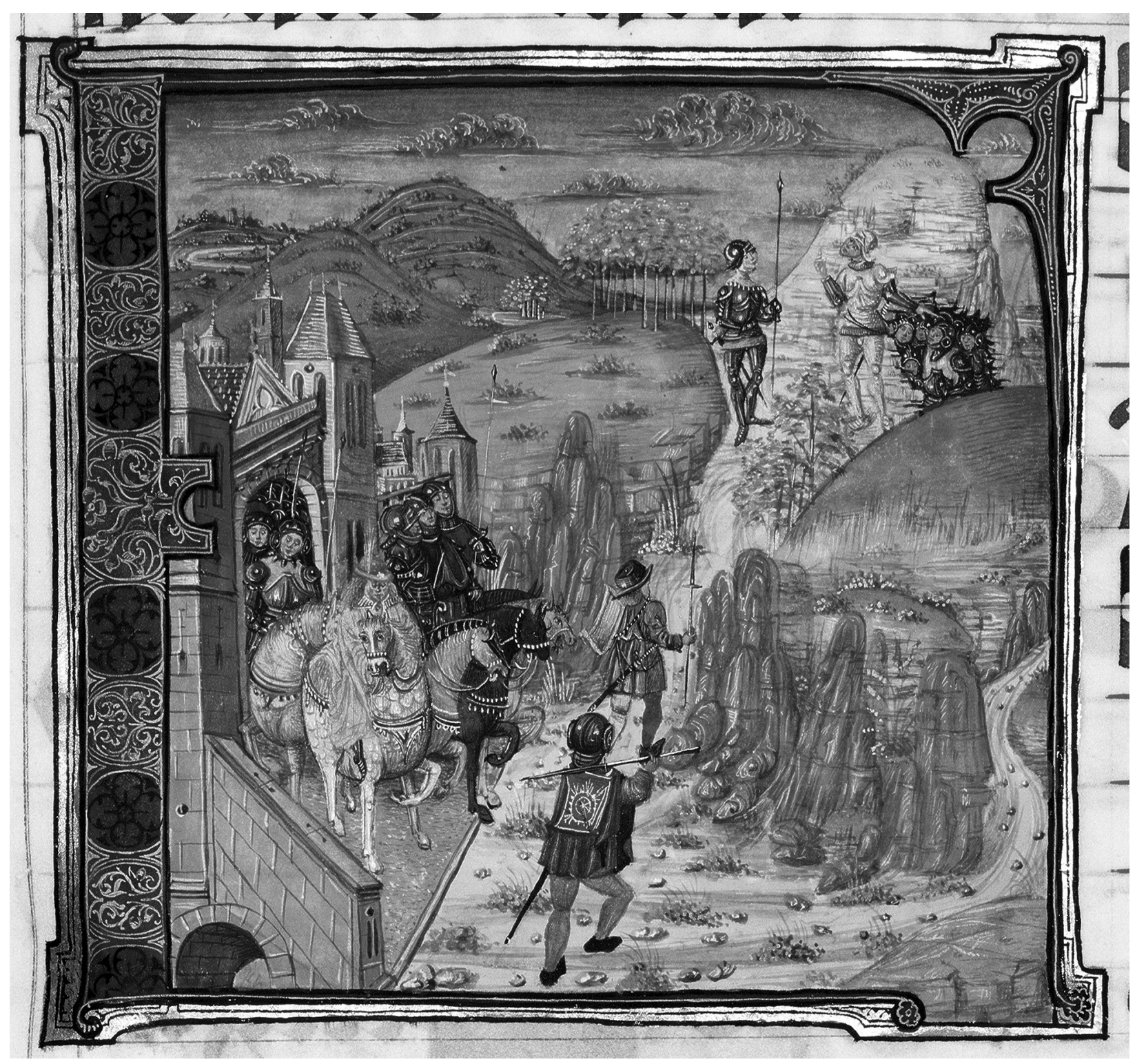

Fig. 11. Initial 'F' / Saul Hunting David, Gradual of King Matthias, 1480s;

Budapest, National Széchényi Library, Department of Manuscripts, Cod. lat. 424, fol. 95r

bottom lips. Furthermore, there are no close analogues with the physiognomic types in the two earlier manuscripts either, despite the fact that Hindman pointed out the similarity of the squat, neckless figures with those in the frontispiece miniature of the Bible historiale - in fact, her only point of connection. ${ }^{43}$ There is also an absence of the blue trees, strung out like beads on the mountain ranges along the horizon, which appear frequently in the manuscript in the National Széchényi Library of Budapest, and the shaping of the boxwood-like trees is also different. In the scene of the Entry into Jerusalem the tree trunks are relatively stumpy, grey and more three-dimensional, with their crowns of leaves spread out horizontally; while in the choir book, the trunks are narrower and modelled in gold, while their foliage is shaped more into upright ellipsoids. These details all indicate that the master, or masters, who worked on the Budapest, Turin and New York manuscripts, could not have been the same as the person who produced this leaf in the Lehman Collection. ${ }^{44}$

The miniature of the Martyrdom of Saint Quentin from the Epistolary that once belonged to the Evangeliary, however, appears to be closer to the Gradual. ${ }^{45}$ Although it is difficult to make out the details on the only known reproduction 
of this leaf, whose present location is unknown, the black-and-white photo in the catalogue for the auction of the Lanna Collection in 1911 does show the saint's face and naked body clearly enough to reveal a similarity with one of the figures of Christ in the Gradual (fol. 3r [Fig. 1], fol. $33 v$ ), while the figure on the left, the presumed donor, ${ }^{46}$ recalls the man in a turban in fol. $141 \mathrm{v}$ of the Budapest manuscript. Although the text in the auction catalogue states that the Martyrdom of Saint Quentin was made by the same person who illuminated the Entry into Jerusalem, ${ }^{47}$ based on the reproduction, I believe that it cannot be ruled out that the miniature of the Evangeliary and the Epistolary was painted by a different person, who may perhaps be identified as the Master of the Gradual. This is, however, impossible to investigate more closely.

In Hindman's brief stylistic analysis, an important role is given to a third leaf that was once believed to have belonged to the Evangeliary, namely the miniature from the Wildenstein Collection. The proposal was based on the similarity between its decorative frame and one of the miniatures in the Cité de Dieu. ${ }^{48}$ The Paris leaf, however, could not have been part of the Evangeliary, for a much more convincing attribution was provided by Gregory T. Clark, who placed the miniature within the œuvre of the Master of the Ghent Gradual, supporting his view with arguments of style and motifs. ${ }^{49}$ Hindman's oversight, however, did have the benefit of raising awareness of the similarity of the decorative frame, which will later play a part in my examination of the question of localisation.

In relation to the Turin and New Haven manuscripts, the literature has posited other possible attributions. Citing James Marrow, Komada put forward the idea that the frontispieces to the Boccaccio manuscript in the Huntington Library of San Marino (California) ${ }^{50}$ and the Miroir de la Salvation humaine in the Glasgow University Library $^{51}$ were early works by the Master of the Gradual. $^{52}$ The similarity in the way the landscape is executed (the high horizon, with tiny scenes placed one above the other), which Komada uses to support the proposal, is not a strong enough foundation, nor is it borne out by the facial types. In addition, Scot McKendrick attributed in a footnote the frontispieces in the two-volume Le Livre des problèmes in the National Library of the Neth-
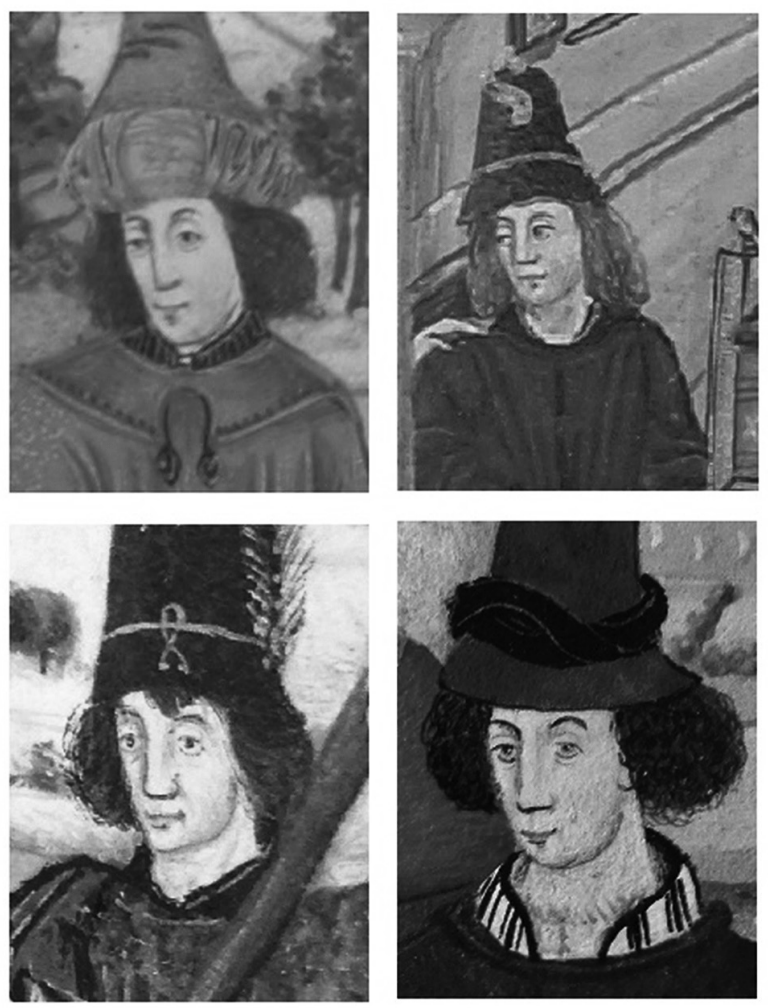

Fig. 12. Detail of figs 5, 16, and 10 and of Duel on Foot, Saint Augustine: Cité de Dieu, vol. 1, c. 1466; Turin, Biblioteca Nazionale Universitaria di Torino, ms. L I 6, fol. 44v
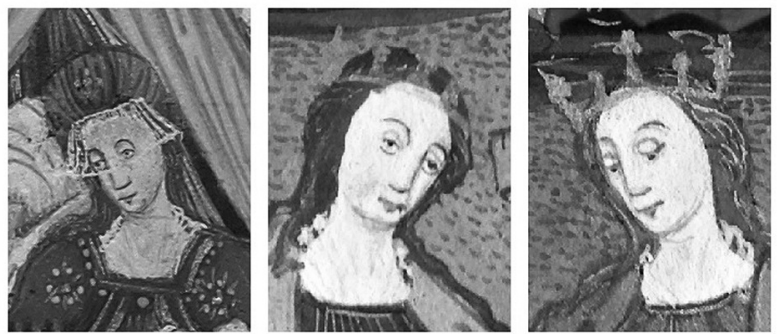

Fig. 13. Judith from Judith Decapitates Holofernes, Petrus Comestor: Bible historiale, 1465-1470, New Haven, Beinecke Rare Book and Manuscript Library, Yale University, ms. 129, vol. 2, fol. 70r; and Saints Barbara and Catherine from Heaven, Saint Augustine: Cité de Dieu, vol. 2, c. 1466, Turin, Archivio di Stato di Torino, ms. Jb. III. 12, fol. 366r

erlands in the Hague to the illustrator of the Turin and New Haven manuscripts. ${ }^{53}$ Although the forming of the landscape and the figures do share a certain resemblance from a distance, when the details are compared from close up - at least as far as the reproductions allow - there seems little justification in assuming that they were made by the same illuminator. The landscape is broken down into layers parallel with the plane of the picture, there are heavily shadowed, cleft cliffs and plastically formed leaves, the faces are square 

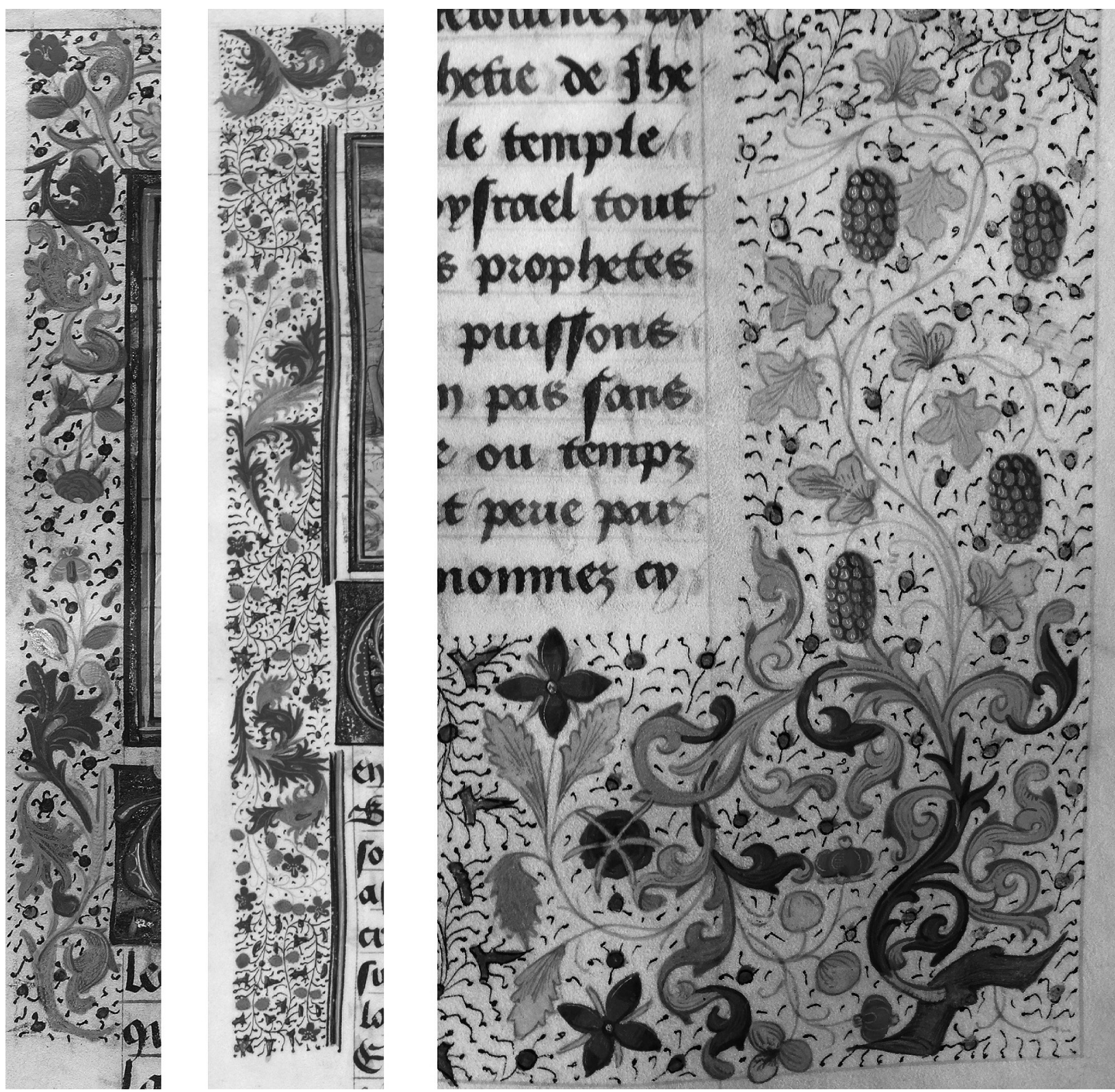

Fig. 14. Borders from Petrus Comestor: Bible historiale, 1465-1470, New Haven, Beinecke Rare Book and Manuscript Library, Yale University, ms. 129, vol. 2, fol. 43r and vol. 1. 49r; and from Saint Augustine: Cité de Dieu, vol. 2. c. 1466, Turin.

Archivio di Stato di Torino, ms. Jb. III. 12, fol. 174r

with sharp features and heavy eyebrows, and the hands are large, with long fingers. All these details are totally different from those seen in the Cité de Dieu and the Bible historiale. The two miniatures from the Hague bear the closest similarity to those images of the stylistically more heterogeneous New Haven manuscript that are most distant from the Turin manuscript; this is the section that includes, for example, fol. 49r (Fig. 15) and fol. $63 \mathrm{r}$ from the first volume.

The connection between the Gradual and the two manuscripts of the Master of the Turin
Augustine is woven more closely together, however, by a Book of Hours at the British Library with reference code Stowe 27. ${ }^{54} \mathrm{~A}$ comparison between the Budapest manuscript and this Book of Hours, which is not discussed anywhere else but in catalogues of the nineteenth century and in the British Library's online catalogue, may on first sight appear futile based on the rushed, sometimes careless execution of the illustrations in the latter, and the rough-and-ready nature of the interior and exterior spaces and the figures. ${ }^{55}$ These deficiencies, however, can be explained by 


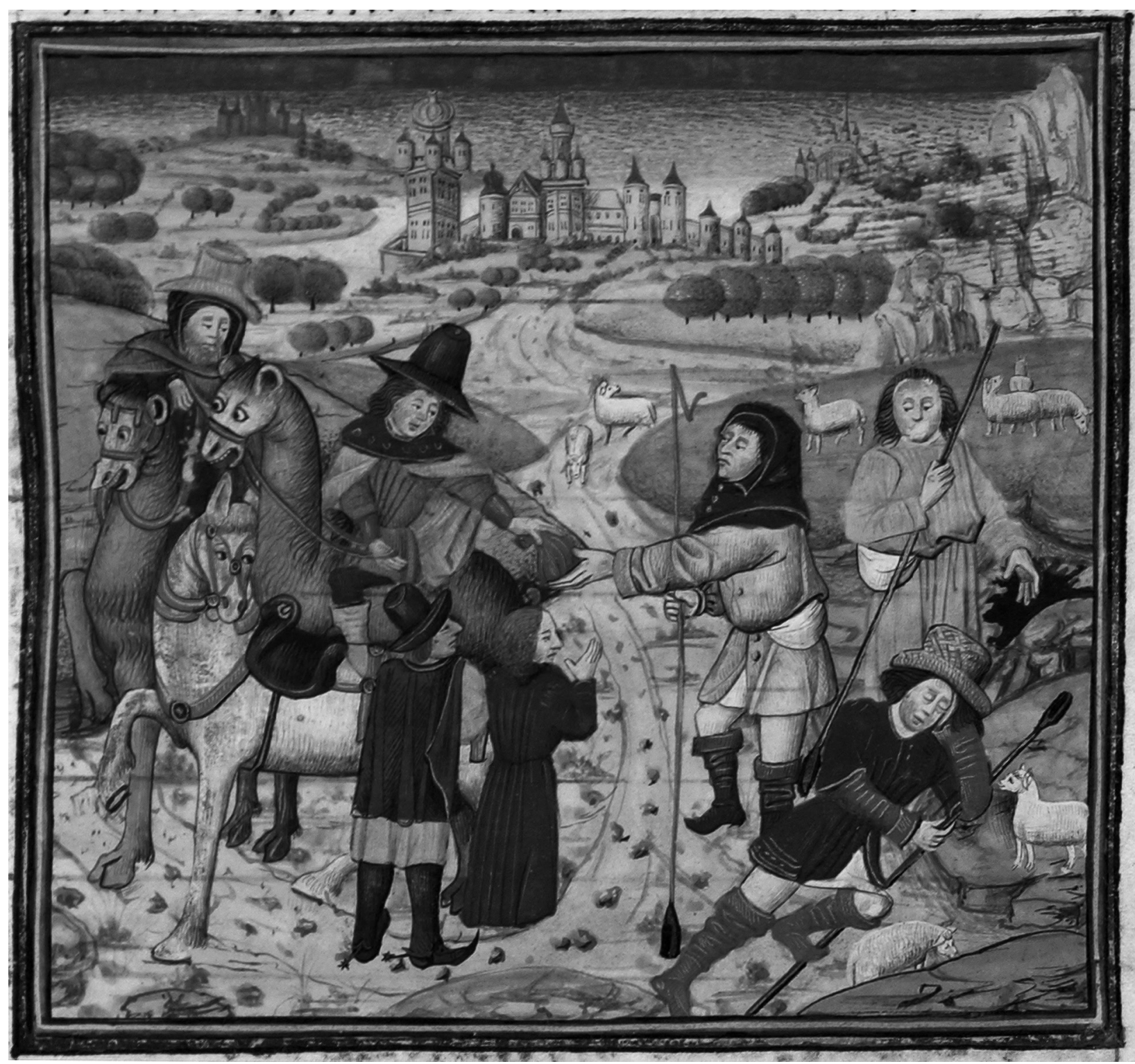

Fig. 15. Joseph Sold by His Brothers, Petrus Comestor: Bible historiale, 1465-1470;

New Haven, Beinecke Rare Book and Manuscript Library, Yale University, ms. 129, vol. 1, fol. 49r

the fact that this Book of Hours appears to be a mass product with far less prestige, and was likely to have been made for the market. Beside these discrepancies, the striking similarities are undeniable. The Book of Hours also features the same distinctive stooped figures from the Gradual, all standing in grotesque poses with their heads raised and protruding forwards from their shoulders. Examples are the figure of Simeon in the scene of the Presentation in the Temple (fol. 66r, Fig. 20), Mary in fol. 55r (Fig. 21), and the soldier murdering the infant in the miniature of the Massacre of the Innocents (fol. 58r, Fig. 22). Mary's face in the scene of the Adoration of the
Magi (with its triangular shape, the raised chin, the curved line where Mary's relatively high forehead meets her hairline, the arched eyebrow, merging with the line of the nose, and the thick lower lip) is identical to the physiognomy of the acolytes in the Gradual. (Fig. 24) The censerbearing acolyte in the Book of Hours (fol. 92r) not only has a face that recalls that of an angel in the Last Judgment of the Gradual, but also similar inverted "V"-shaped folds in the clothing, which is tucked in at the waist. (Fig. 25) The elderly, bearded figures in the two manuscripts are also very similar, sharing the same drooping mouths, with their thick, dot-like lower lips, and 


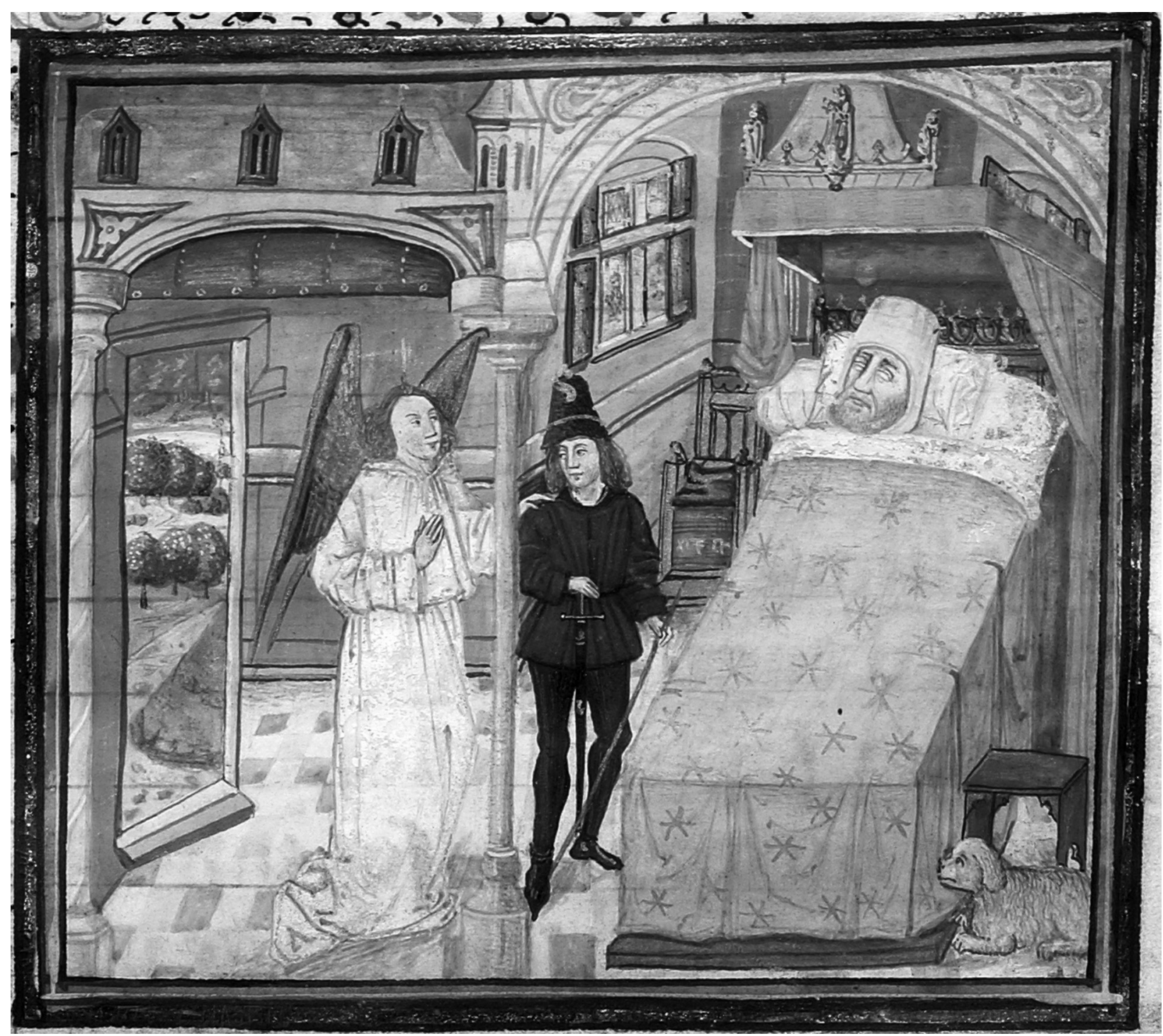

Fig. 16. Death of Tobias, Petrus Comestor: Bible historiale, 1465-1470;

New Haven, Beinecke Rare Book and Manuscript Library, Yale University, ms. 129, vol. 2, fol. 43r

the same dense black eyebrows, curving together with the nose. ${ }^{56}$ The stooping, round-faced soldier with the bulging eyes in the Massacre of the Innocents also seems familiar from one of the pages in the Gradual (fol. 157r).

There are points of connection not only with the Budapest choir book, however, but with the two earlier manuscripts as well. The figure of Gabriel in the Annunciation recalls the angel in the scene of the Death of Tobias in the Bible historiale. (Fig. 27) There are also similarities between certain female faces. The physiognomy of Judith, in the New Haven manuscript, and of the female saints in the Last Judgment in the Cité de Dieu - the long head, the highly raised, arched eyebrow, its continuation into the long, straight nose, and the distinctive lips - resembles the face of Mary in the Book of Hours, in the scenes of the Nativity, the Presentation in the Temple, and particularly the Visitation. (Fig. 26) The blue onion-domed buildings in the backgrounds of the Gradual and the Bible historiale also reappear in the London Book of Hours, and the interiors are likewise drawn without recourse to the rules of perspective. There is another tiny detail that links this Book of Hours with the Gradual. In both manuscripts, the iron ties holding together blocks of stone are indicated with the same sweeping strokes that broaden out into dots at each end. (Figs. 7, 11, 22) Similar lines can also be found in the Bible historiale, only these are straighter and more disciplined (Fig. 5), which are close to 


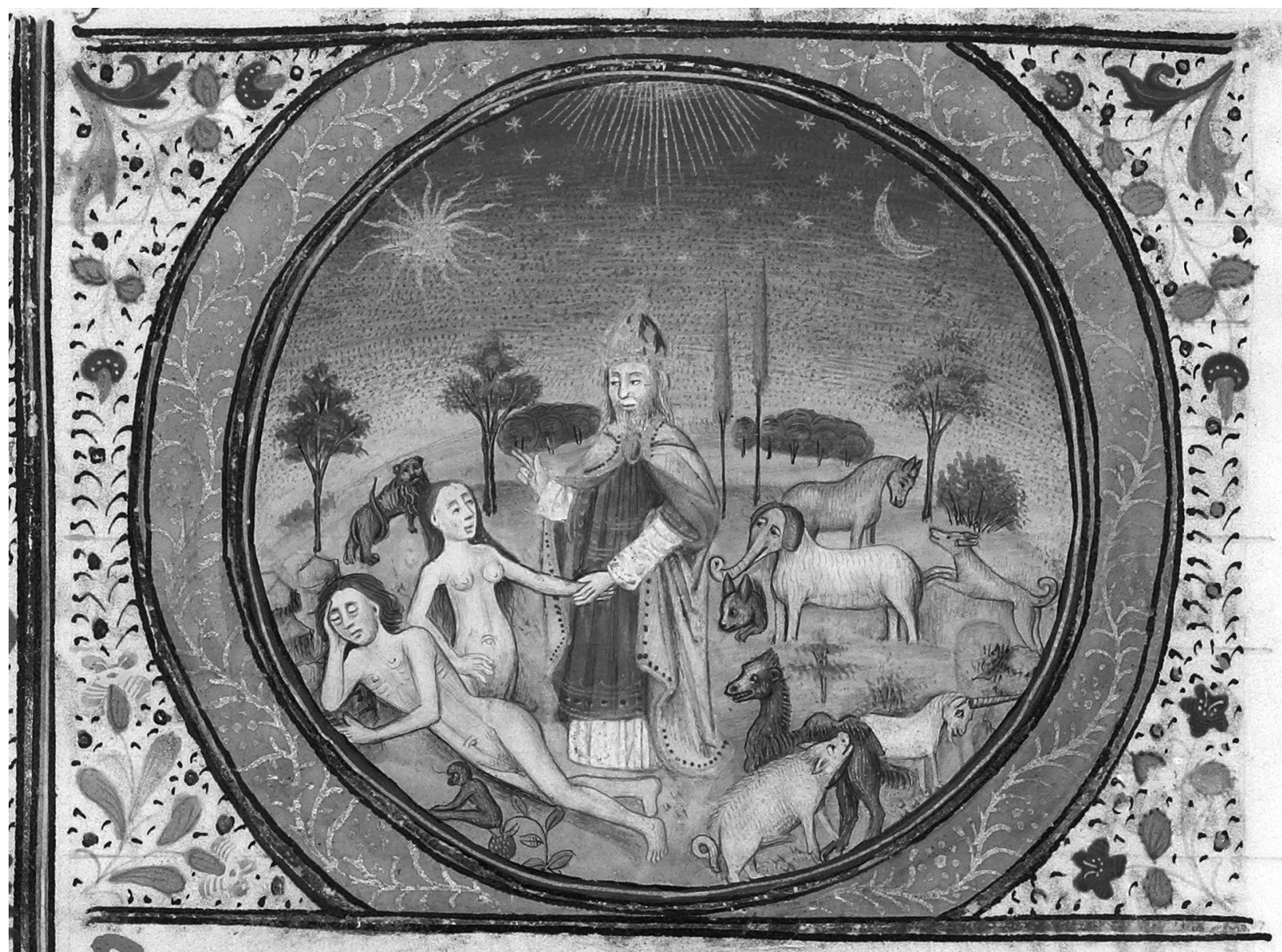

Fig. 17. The Creation of Eve, Petrus Comestor: Bible historiale, 1465-1470;

New Haven, Beinecke Rare Book and Manuscript Library, Yale University, ms. 129, vol. 1, fol. 8v

the even more precise method used in the Cité de Dieu (AST Jb. III. 12, fol. 43r, Fig. 27). ${ }^{57}$

When it comes to dating the Book of Hours, as it shares common traits with both the Gradual and the Bible historiale, it was probably made at some time between the two, which would allow us to narrow down the range of 1460-1480, stated in the online catalogue, to the 1470 s.

In order to investigate further the identity of the illuminator of the Gradual of King Matthias, I consider the Turin Cité de Dieu, the New Haven Bible historiale and the London Book of Hours to be relevant. Although the Book of Hours reinforces the connection between the Gradual and the two earlier manuscripts, the differences, which manifest themselves primarily in the types of figures and faces, continue to warrant caution; the illustrations containing such differences were less likely to have been made by a single hand, so the more probable interpretation is that these manuscripts were painted by several illuminators who had worked together at some point. This group of works, however, is still too small to permit the different hands working on them to be clearly differentiated, or to establish with any certainty the relationship between the illuminators.

Approaching the matter from the aspect of the organisation of work also raises difficulties, for it is far from clear what kind of structure is meant by the frequently used term "workshop," in the sense of how many assistants and apprentices were engaged by the master. ${ }^{58}$ As Jonathan J. G. Alexander pointed out, it should not be assumed that the practice in the late fifteenth century was the same as the future bustling workshops of the Renaissance, as there were probably far fewer people at work alongside the master, no more than a couple of pupils and assistants. ${ }^{59}$ Marc Gil argues in favour of a family-based workshop, which would also have used the services of one or two apprentices. ${ }^{60}$ The sources provide 


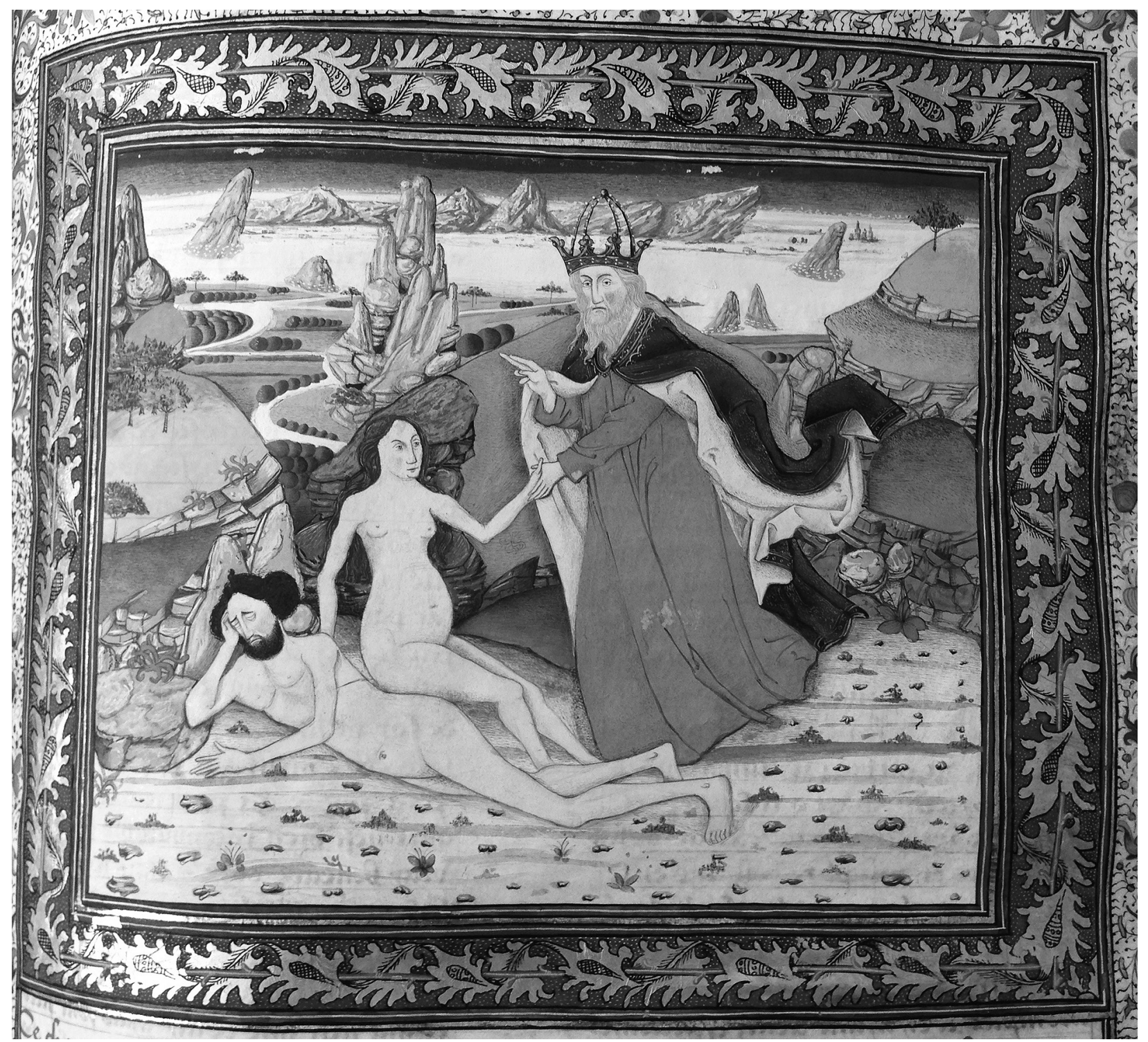

Fig. 18. The Creation of Eve, Saint Augustine: Cité de Dieu, vol. 2, c. 1466; Turin, Archivio di Stato di Torino, ms. Jb. III. 12, fol. 25r

no clear guidance on workshop structure, and it is rarely possible to draw conclusions from specific instances. Nevertheless, in order to obtain an approximate idea of the kinds of models of work organisation for which there is documentary evidence, we can turn to the book written by Dominique Vanwijnsberghe, which provides a comprehensive investigation of the sources pertaining to miniature painting in Tournai. ${ }^{61}$ The reason why Tournai is exceptionally suitable from the point of view of this paper will be explained in the next chapter, on localisation. Vanwijnsberghe outlines a picture of how work was organised based on the regulations from the year 1480 of the guild of painters and glasswork- ers, which also comprised illuminators, and on a nowhere-near complete list of the names of illuminators and apprentices that attained the rank of master. In addition to masters, who were full members of the guild, and apprentices, the guild regulations distinguished two further, less easily identifiable groups of workers in the book illustrating profession: these were compagnons, who had already served two years as apprentices but had not yet risen to the rank of master, usually for financial reasons, and serviteurs, who performed more menial tasks, and who perhaps were not even given professional training. ${ }^{62}$ A comparison of the lists of masters and apprentices shows that only a small proportion of the masters on 


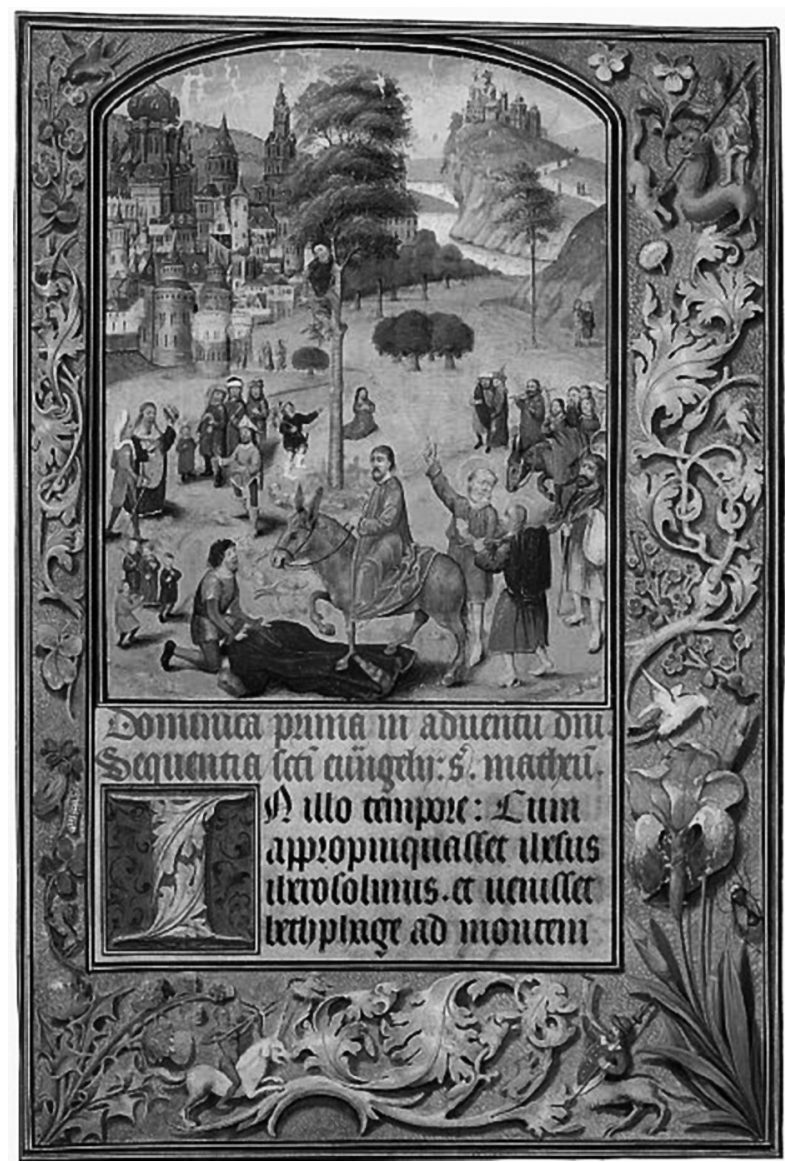

Fig. 19. Entry into Jerusalem, Leaf from an Evangeliary, c. 1480-1490; New York, Metropolitan Museum of Art, Robert

Lehman Collection, 1975.1.2471, www.metmuseum.org

the list taught more than one apprentice at a time. ${ }^{63}$ The majority of apprentices, meanwhile, did not attain the rank of master after completing their apprenticeships (at least not in Tournai), which led Vanwijnsberghe to speculate that some of them continued to work alongside their master as compagnons. ${ }^{64}$ There are two cases where it can be shown that a master taught two apprentices simultaneously. ${ }^{65}$ Given that compagnons and serviteurs could be employed without any binding contracts, and the fact that the guild regulations permitted work to be subcontracted, everything seems to have been in place to enable large commissions to be fulfilled rapidly by organising the work accordingly, ${ }^{66}$ which would have enabled some workshops to operate with several employees. Since there is virtually no trace of any kind in the written records about the compagnons, who were perfectly capable of working independently, and who may be more relevant than the apprentices when examining aspects of style, it is extremely difficult to formu- late a historically authentic picture of the structure of workshops at the time, which could then be applied in connection with the surviving manuscripts and artworks. ${ }^{67}$

It is also problematic to correlate the (to a certain extent flexible) frameworks that are outlined by the documents with the actual structures of working, which probably differed somewhat for each given situation. Even in the case of an illuminator whose ouvre is large and for whom there are many reliable sources, such as Willem Vrelant of Bruges, there is still the possibility of opposing views arising. ${ }^{68}$ It is at present impossible to determine the type of structure by which the group surrounding the Turin Cité de Dieu and the Gradual came into being, and only certain hypotheses may be put forward regarding this. The stylistic heterogeneity of the New Haven Bible historiale already raised the possibility of several hands, and the master of the Turin manuscript may have relied on extra help during the work process, not only from another illuminator, but perhaps also from an assistant. (The status of the people involved is hard to judge on the basis of quality alone). As for the London Book of Hours, it is possible that this was an early work by the Master of the Gradual, produced with less attention to detail for sale on the open market, which partly follows the types of figures used in the Bible historiale. An inspection of the figures in the background of the Gradual, together with the sketchy execution of some of its smaller figures, would suggest there is some basis to this supposition. Differences in quality (by which we mean mainly the diligence of execution, rather than, for example, spatial or anatomical precision) may have arisen due to differences in the available time, the prestige of the task and the expected amount of payment. ${ }^{69}$ Naturally, when faced with just these two works, which differ so greatly in their quality level, it is perfectly justifiable to raise doubts. Numerous stylistic characteristics found in the Gradual - the complex buildings, the distinctive conical cliffs in the background scenery, and the blue trees lined up like a string of beads along the mountains on the horizon - are completely absent from the Book of Hours. The most we can say with a degree of certainty is that the London Book of Hours is linked, in some way, to the workshop production of the Master of the Turin Augustine and to the 
related activities in the Netherlands of the Master of the Gradual.

Taking all this into account, I consider it justified and reasonable, when attempting a precise localisation of the origins of the illuminator who worked on the Gradual, to refer to the evidence offered by the Turin, New Haven and London manuscripts.

\section{Localising the Master of the Turin Augustine and his Workshop}

Because of the supposed similarity with Loyset Liédet and the commissioner of the Cité de Dieu, Antoine de Bourgogne (1421-1504), Hindman localised the place where this group of manuscripts was made to Bruges. ${ }^{70}$ The practice of making localisations around Bruges, without deeper considerations of style, was objected to by Akiko Komada, who, in her doctoral dissertation on the manuscripts of the Bible historiale produced in Northern France and the Netherlands, localised the place where the master worked to Tournai. ${ }^{71}$ Below I would like to provide further evidence in support of Komada's arguments for a localisation around Tournai.

An important role in this may be played by the London Book of Hours, for the unique features of the calendar and the litany of the saints points to the use of Tournai. The celebration of the consecration of Notre-Dame Cathedral in Tournai on 9th May ("dedicatio ecclesie Tornai") is highlighted in red, as is 1st October, the feast day of Saint Piatus (d. c. 286), who converted the people of the city to Christianity. Additionally, albeit only in simple, black ink, 20th February is also marked for the feast of Saint Eleutherius (d. c. 532), first Bishop of Tournai. Both saints also appear in the litany.

The scribe of the Cité de Dieu also connects the Master of the Turin Augustine to this region. According to its colophon, it was copied by Jean du Quesne, who was active in Lille, just 30 kilometres from Tournai. Scot McKendrick and. with reference to him, Akiko Komada consider the Bible historiale in the Beinecke Library also to be the work of Du Quesne, ${ }^{72}$ although in the absence of signatures, this attribution cannot be accepted unconditionally. Even the person of Jean du Quesne is not, in itself, a guarantee that

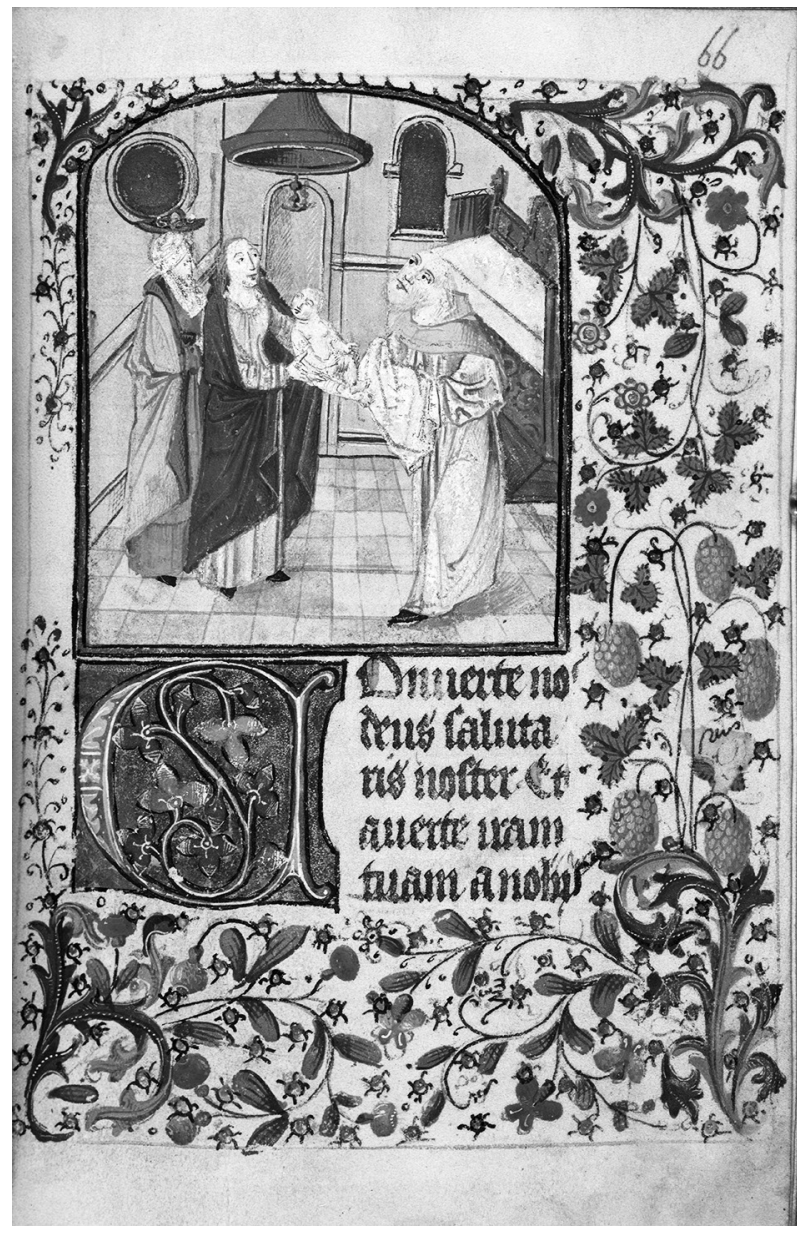

Fig. 20. Presentation in the Temple, Book of Hours, c. 1470-1480; London, British Library, ms. Stowe 27, fol. 66r, (C) British Library Board, ms. Stowe 27

the miniatures were painted in the manuscript in Lille or its surroundings, for out of eleven signed works, most were illustrated by illuminators from Bruges, and only three were decorated by local masters. ${ }^{73}$ Accompanied by further arguments that point towards Tournai, however, the scribe from Lille also adds support to the suggested localisation.

A large part of the iconographic and compositional models of the works also leads one's attention in the direction of Tournai and its environs. Komada discovered the predecessor to the New Haven Bible historiale in a similar work from a few decades earlier, in the manuscript Mazarine 312, dated to around 1440, which, in her stylistic analysis, may have originated from the area around Tournai and Cambrai. ${ }^{74}$ Mazarine 312 served as the model for both the text and the content, and is the source of the emphasis on the cycle of Creation, the swapping around of the 
portrayals of the first two days, and the medallion format. ${ }^{75}$ (Fig. 17) It is also the origin of the peculiar illustration in fol. $289 \mathrm{v}$ of the second volume of Beinecke 129, in which the illuminator has misconstrued the motif of the winged mitre, and has instead attached the wings to the man's neck. ${ }^{76}$ To the list of parallels can be added the analogue solution of the scene of Elijah on the Fiery Chariot (Mazarine 312, fol. 120r and Beinecke 129, vol. 2, fol. 1r). Since Komada assumed that this specific copy had a direct effect - an assumption which is reinforced by the matching texts - the provenance of Mazarine 312 becomes a matter of importance. At the time the copy in the Beinecke Library was made, the manuscript which is in Paris today was owned by Antoine de Crèvecoeur, a nobleman of Artois. ${ }^{77}$ As Artois is not so close to Tournai, this would not of itself bring much weight to the idea that the manuscript originated in Tournai. If a direct connection is not insisted upon, however, then the local tradition of images and texts would explain the similarities, which have as yet no other witnesses besides these two manuscripts.

In the Cité de Dieu, the tradition of illustration used in the region around Lille and Tournai is more clearly discernible. The miniatures in the Turin manuscript faithfully follow a copy from several decades earlier, dated to 1420-1435, which is now in Brussels (KBR 9005), and to which the literature was first alerted by Alexandre Laborde in 1909. ${ }^{78}$ Judging from its provenance, this manuscript also came from the Lille region, for it was made for Gui Guilbaut (d. 1447), head of the Chambres des Comptes in Lille, and was, according to an inventory of 1469, received from the governor of Lille by Philip the Good. ${ }^{79}$ It is possible that, at the time when the Turin copy of 1466 was being illustrated, the manuscript was still present in Lille, and was used directly as a model by the Master of the Turin Augustine. Even if the manuscript of Gui Guilbaut was no longer present, certain remnants of the visual forebears would still have been available in some form or another, even after the book left Lille. Of course, it is not inconceivable that Antoine de Bourgogne borrowed the original manuscript from his father's library and commissioned a copy of it for himself.

By whichever means the Master of the Turin Augustine came across the original, the frontis- piece miniature of KBR 9005 established a local iconographic type, whose legacy indisputably includes the frontispiece of the Turin manuscript. (Fig. 28) The depiction in KBR 9005 is the first to include, in a single composition, Saint Augustine and the legend of the divine origin of the French royal title, included in the text by the translator, Raoul de Presles: this was the moment when the Holy Spirit, in the form of a dove, carried down the holy anointing oil to Clovis I (466-511), King of the Franks. ${ }^{80}$ The local and regional influence of Gui Guilbaut's manuscript can be seen in another copy of the Cité de Dieu (KBR 9015), which belonged to Jean Chevrot (c. 1380?-1460), Bishop of Tournai, and which opens with a very similar composition. ${ }^{81}$ Chevrot's manuscript has several demonstrable links to the region. Firstly, the scribe, Nicolas Cotins, a Dominican monk from Amiens, was verifiably present in Lille in 1460, in addition to which he acted as "inquisiteur" of Thérouanne and Tournai. ${ }^{82}$ Moreover, the illuminators were also from this area: apart from the frontispiece of the first volume, which was influenced by Jan van Eyck and can be attributed to a master from Bruges, all the other illustrations were probably made in the workshop of the Master of the Ghent Privileges. ${ }^{83}$

This composition is continued further in the British Library Cité de Dieu, whose frontispiece was painted by the Master of the Vienna and Copenhagen Golden Fleece. ${ }^{84}$ The illuminator's œeuvre has been reconstructed in recent years, and his activity has been localised to Lille, based on the provenance of the works dated to the $1460 \mathrm{~s}$ and $1470 \mathrm{~s}$, and on the place where identifiable collaborators on certain manuscripts - fellow illuminators, scribe and bookbinder were known to be active. ${ }^{85}$ It is not easy to decide which of the manuscripts was used by the Master of the Golden Fleece as his archetype: in his painting of the frontispiece, did he follow the copy owned by Gui Guilbaut or the one belonging to Jean Chevrot, or did he arrive at this composition through the mediation of the Master of the Turin Augustine? The latter option is supported by the posture in which Clovis stands, and his attire, which are identical, down to the tiniest details, to those in the image of the ruler portrayed in the Turin manuscript, including the fur trimming on his clothes, the sword at his 


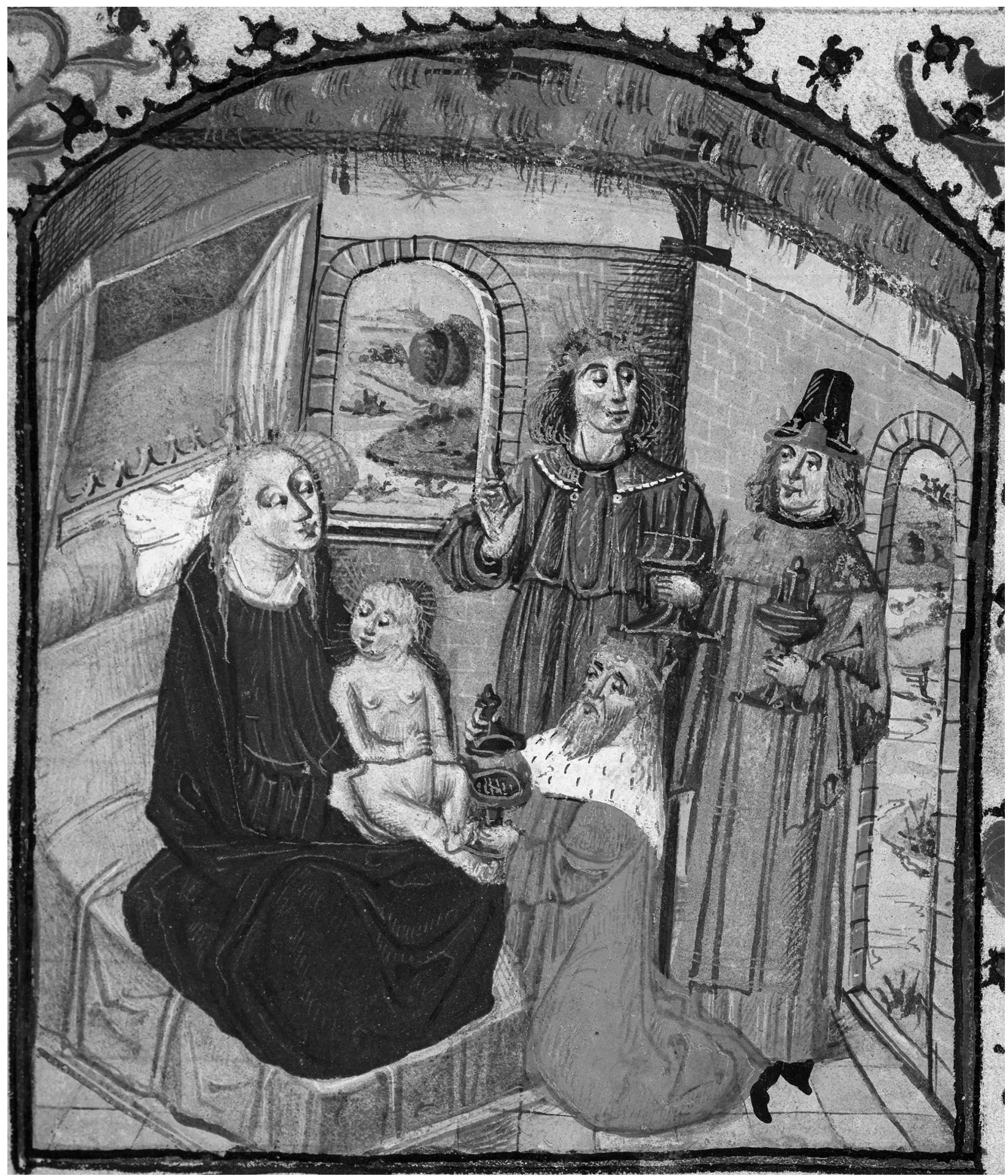

Fig. 21. Adoration of the Magi, Book of Hours, c. 1470-1480;

London, British Library, ms. Stowe 27, fol. 55r, (c) British Library Board, ms. Stowe 27

belt, the angle of his raised head and the position of his legs. The model for the other miniatures in the London manuscript, those which were not painted by the Master of the Golden Fleece, was taken either from the Turin manuscript or from KBR 9005, but it is difficult to specify which of these was used. (Jean Chevrot's copy is out of the question, because several of the miniatures it contains do not fit in with the same tradition of illustration.) In the scene of The Emperor before the Pope (BL, Royal 14 D I, fol. $224 v$ ), the Pope's cross and the Emperor's hand 


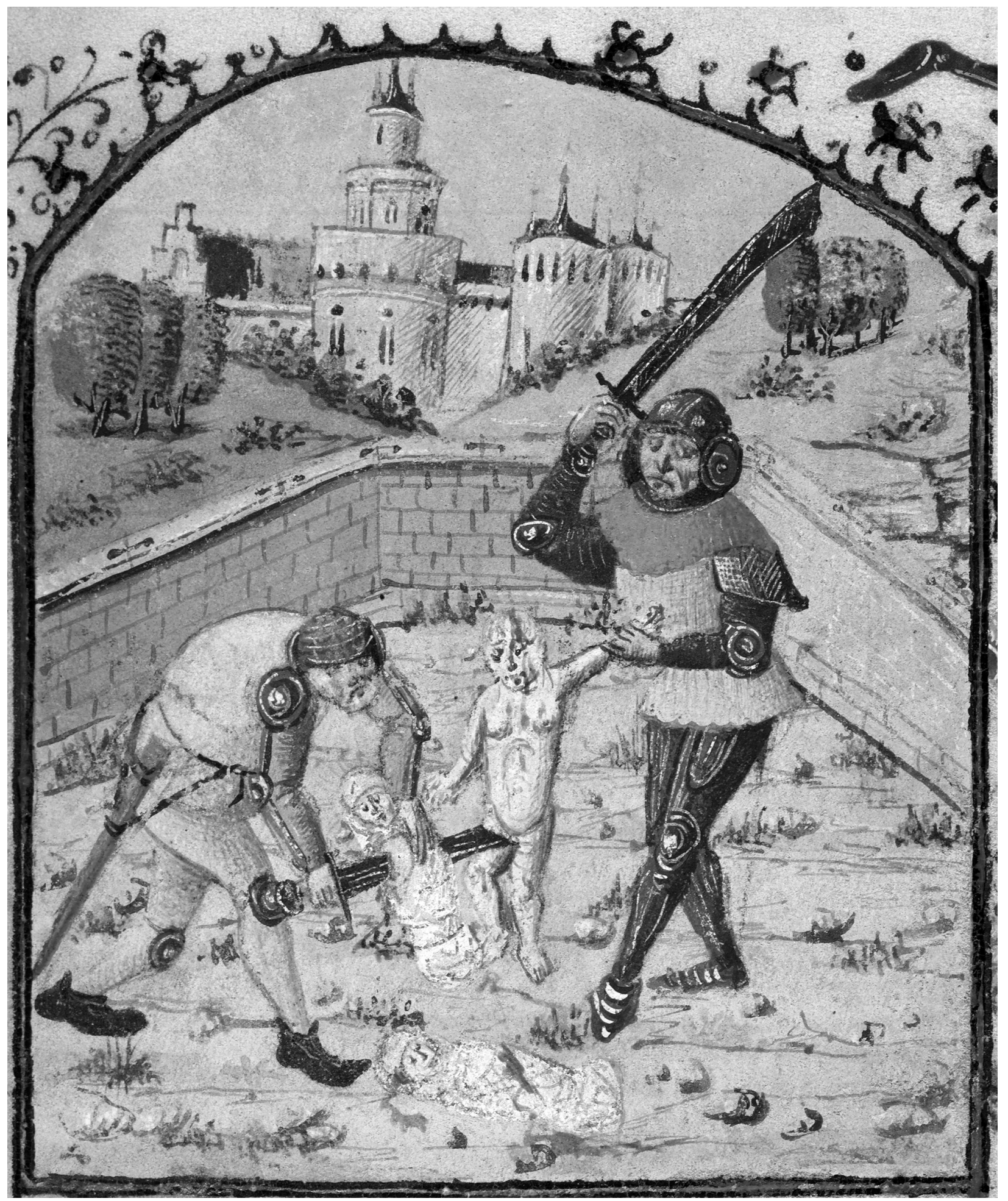

Fig. 22. Massacre of the Innocents, Book of Hours, c. 1470-1480;

London, British Library, ms. Stowe 27, fol. 58r, (C) British Library Board, ms. Stowe 27

gestures suggest that the Turin manuscript was in front of the eyes of the Master of the Golden Fleece (Fig. 8), while in the miniature showing the pagan gods (BL, Royal 14 D I, fol. 299v), the dragon biting its own tail that can be seen above the head of the female figure, symbolising the Earth, is closer to the Brussels copy than the one from Turin (BNU L I 6, 319v). ${ }^{86}$ It cannot be ruled out that the illuminator was aware of both manuscripts, and of course we must not lose 


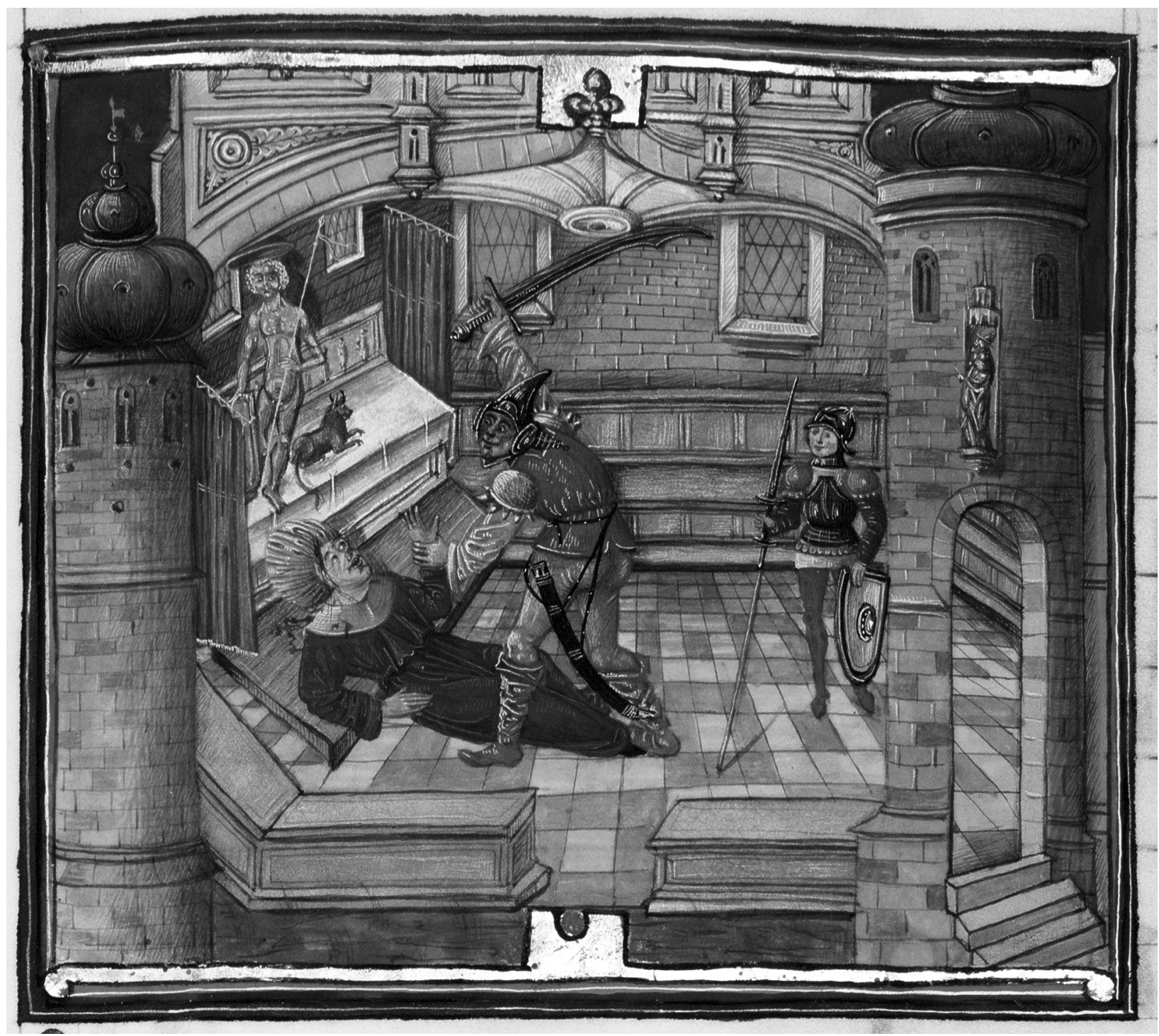

Fig. 23. Detail of Initial 'I' / Mattathias Killing a Hellenistic Jew (?). Gradual of King Matthias, 1480s,

Budapest, National Széchényi Library, Department of Manuscripts, Cod. lat. 424, fol. 157r

sight of the possible role played by manuscripts that have since been lost.

Certain iconographic peculiarities in the London Book of Hours also indicate it was made in Tournai, for they follow, in the main, the solutions used by the Master of the Ghent Privileges and his workshop. An example of this is the figure of Mary, sitting on a donkey, in the scene of the Flight into Egypt (fol. 61r), which features on a page of the so-called Sam Fogg Hours in a very similar fashion. ${ }^{87}$ The image of Mary sitting cross-legged on a bed with the upper half raised at an angle, with a pillow on top, seen in fol. 55r of Stowe 27 (Fig. 21), is familiar from the scene of the Nativity in the same Book of Hours, and from the miniature of The Adoration of the Magi in a
Book of Hours also attributed to the Master of the Ghent Privileges, which is now in Warsaw. ${ }^{88}$ Some of the decorative frames in the Turin manuscript also lead to the Master of the Ghent Privileges, and his follower, the Master of the Ghent Gradual, for these masters were the originators of the kind of frame decorated with golden leaves weaving around a thin cane, which surrounds several of the miniatures in the Cité de Dieu. ${ }^{89}$ (Fig. 10) Such frames can be seen in the eponymous work by the Master of the Ghent Privileges, the Statuts et privilèges de Gand et Flandre (ÖNB 2583 fols. 64r, 226r), as well as in a number of works decorated by the Master of the Ghent Gradual. ${ }^{90}$ Such a frame also encircles the frontispiece miniature of the second vol- 

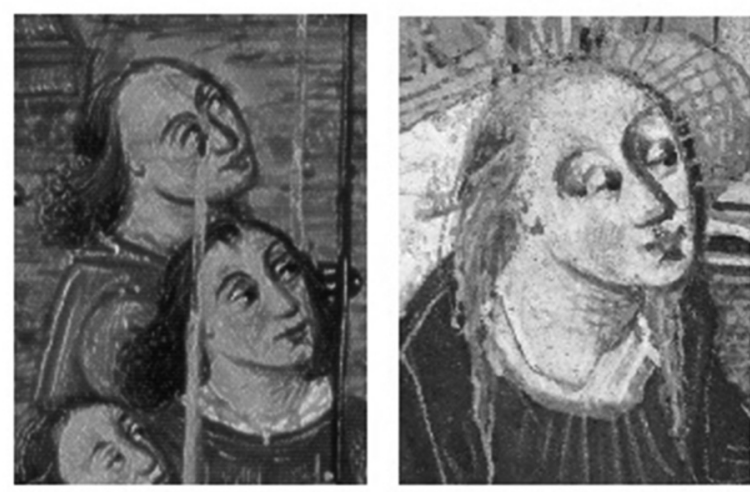

Fig. 24. Detail of Initial 'E' / Procession, Gradual of King Matthias, 1480s; Budapest, National Széchényi Library, Department of Manuscripts, Cod. lat. 424, fol. 50r and fig. 21
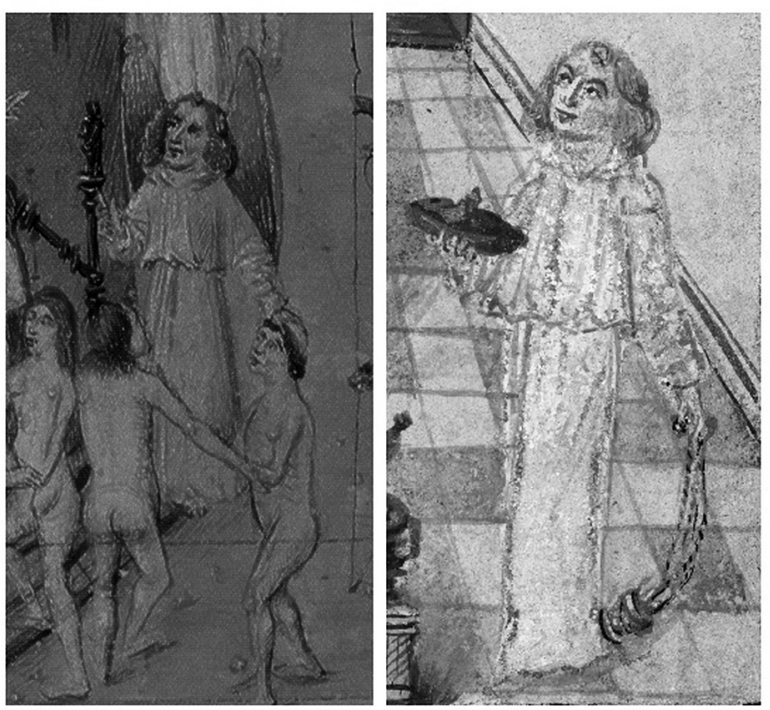

Fig. 25. Detail of fig. 4 and Funeral Service, Book of Hours, c. 1470-1480; London, British Library, ms. Stowe 27, fol. 92r. (C) British Library Board, ms. Stowe 27
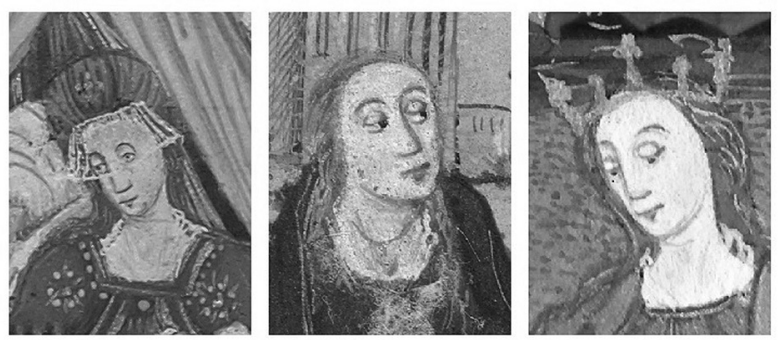

Fig. 26. Judith from Judith Decapitates Holofernes, Petrus Comestor: Bible historiale, 1465-1470, New Haven, Beinecke Rare Book and Manuscript Library. Yale University, ms. 129. vol. 2, fol. 70r; Mary from the Visitation, Book of Hours, c. 1470-1480, London, British Library, ms. Stowe 27, fol. 38r, (C) British Library Board, ms. Stowe 27; and Saint Catherine from Heaven, Saint Augustine: Cité de Dieu, vol. 2, c. 1466 , Turin, Archivio di Stato di Torino, ms. Jb. III. 12, fol. 366r ume of Jean Chevrot's copy of the Cité de Dieu (KBR 9016 fol. 1r). ${ }^{91}$ The similarity between the decorative frames was pointed out by Hindman, who was led by this to make a false attribution of the miniature in the Musée Marmottan. ${ }^{92}$ Akiko Komada - equipped with the correct attribution - used the similarity of the ornamentation as an argument in support of a localisation around Tournai. $^{93}$ With regard to the localisation of the Master of the Ghent Privileges, Anne van Buren was already arguing in favour of Tournai in an article of 1985, while in a monograph of the illuminator and his circle, Gregory T. Clark, bearing in mind the original owners of the manuscripts attributed to the Master of the Ghent Privileges, the liturgical characteristics of the manuscripts, and the collaborative partners of the workshop, came to the conclusion that the Master of the Ghent Privileges and his follower, the Master of the Ghent Gradual probably operated workshops at the same time in both Ghent and Tournai. ${ }^{94}$

The group of manuscripts centred around the Master of the Turin Augustine can also be associated with the same region by virtue of their stylistic connections. The closest similarities are found with the works of the Master of the Vienna and Copenhagen Golden Fleece, who was active in Lille. The close similarity is indicated by the fact that Dagmar Thoss and Otto Pächt attributed the Turin manuscript of Saint Augustine to the same person who made the Histoire de la Toison d'Or, which gave the master of Lille his conventional name, and which is now kept in separate parts in Copenhagen, Vienna, Dijon and Épinal. ${ }^{95}$ In views of cities, the amalgamation of buildings and the rich detailing of interiors and architectural features, as well as the high horizon, are indeed very similar in the works of both illuminators, although the Master of the Golden Fleece tends to be more adroit at portraying perspective in the architecture and rooms. Seen from closer at hand, the facial types also reveal certain differences. The round faces, often featuring double chins and bold laugh lines, so typical in the works of the Master of the Golden Fleece, are not found at all in the repertoire of the Master of the Turin Augustine. And although the faces in the frontispiece miniatures in the volumes of the Histoire de la Toison d'Or may recall Saint Augustine or Clovis I from the Turin Cité de Dieu, the protruding chins used by the Mas- 

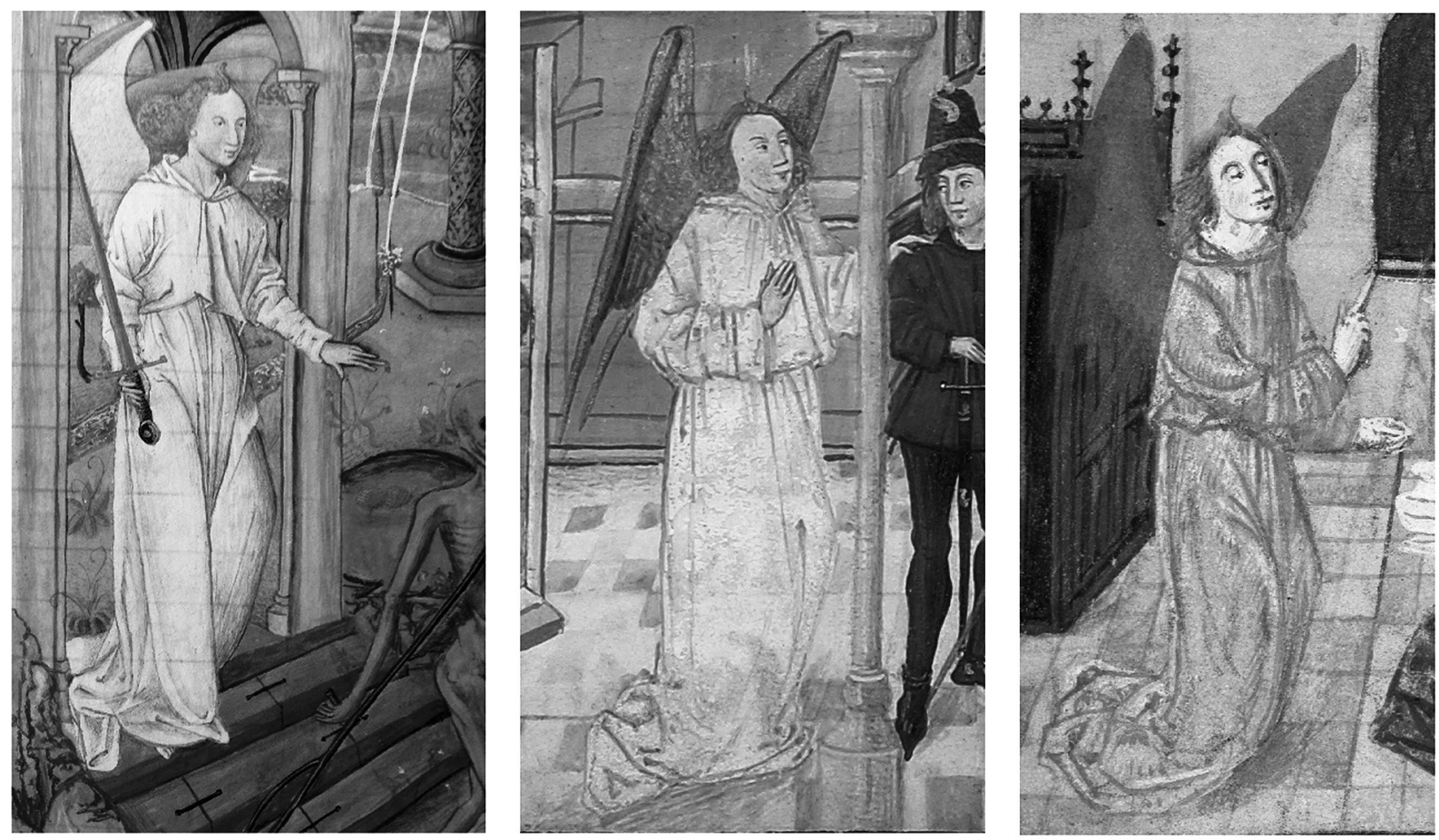

Fig. 27. Detail of Expulsion from Paradise, Saint Augustine: Cité de Dieu, vol. 2, c. 1466, Turin, Archivio di Stato di Torino, ms. Jb. III. 12, fol. 43r; fig. 16 and Annunciation, Book of Hours, c. 1470-1480,

London, British Library, ms. Stowe 27, fol. 22r, (c) British Library Board, ms. Stowe 27

ter of the Golden Fleece, marked with a separate line, and the long, slightly curving noses found in the Turin manuscript, are distinctive and distinguishing hallmarks of a kind which cannot be seen in the works of the other illuminator.

A page cut out of a Chroniques d'Angleterre, dated to the second half of the $1470 \mathrm{~s}$, bears close similarities with the works of both the Master of the Turin Augustine and the Master of the Gradual. This page, together with several others taken from the same manuscript, are generally attributed to the Master of the Golden Fleece. ${ }^{96}$ The inexpert grasp of perspective seen in the interiors - which is otherwise uncommon in the works of the Master of the Golden Fleece - is strongly reminiscent of the methods used in the Gradual and in the Turin Cité de Dieu: the lines that lead deeply into the pictorial space rise up too steeply, and the parallel lines are in some places clearly diverging from one another. Similarities can also be detected among the facial types. The faces that narrow towards the chin, the slightly forward-leaning heads, the straight noses joined in the same line as the arching eyebrows, and the distinctive lips are all traits that may be familiar from the Gradual. In addition, in the scene on the right of the page, the physiognomy of the figure behind Edward III's right shoulder closely resembles the faces of Romulus in the Cité de Dieu, and of the male figure in the Presentation of Samuel in the Bible historiale. (Fig. 5) In the case of heads shown in three-quarter profile, the slightly distorted facial expression caused by the mouth being misplaced in relation with the nose, as can be seen on the two men next to Edward III or the young man standing on the right of the French King, is also quite common in the Gradual, appearing on the face of the figure on the right edge of fol. 10r (Fig. 2), and in the greenhooded figure in fol. $165 \mathrm{v}$, and the same expression can also be observed in some of the female figures in the Book of Hours and the Bible historiale. (Fig. 26) These close similarities in style, and the iconographic relationship with the volumes of the Cité de Dieu, detailed above, justify the conclusion that the two illuminators must have been close to each other geographically as well.

In her reasoning in favour of the Tournai localisation, Akiko Komada also put forward a number of stylistic arguments. She assembled a corpus of roughly two dozen manuscripts, mostly books of hours with liturgical characteristics that 


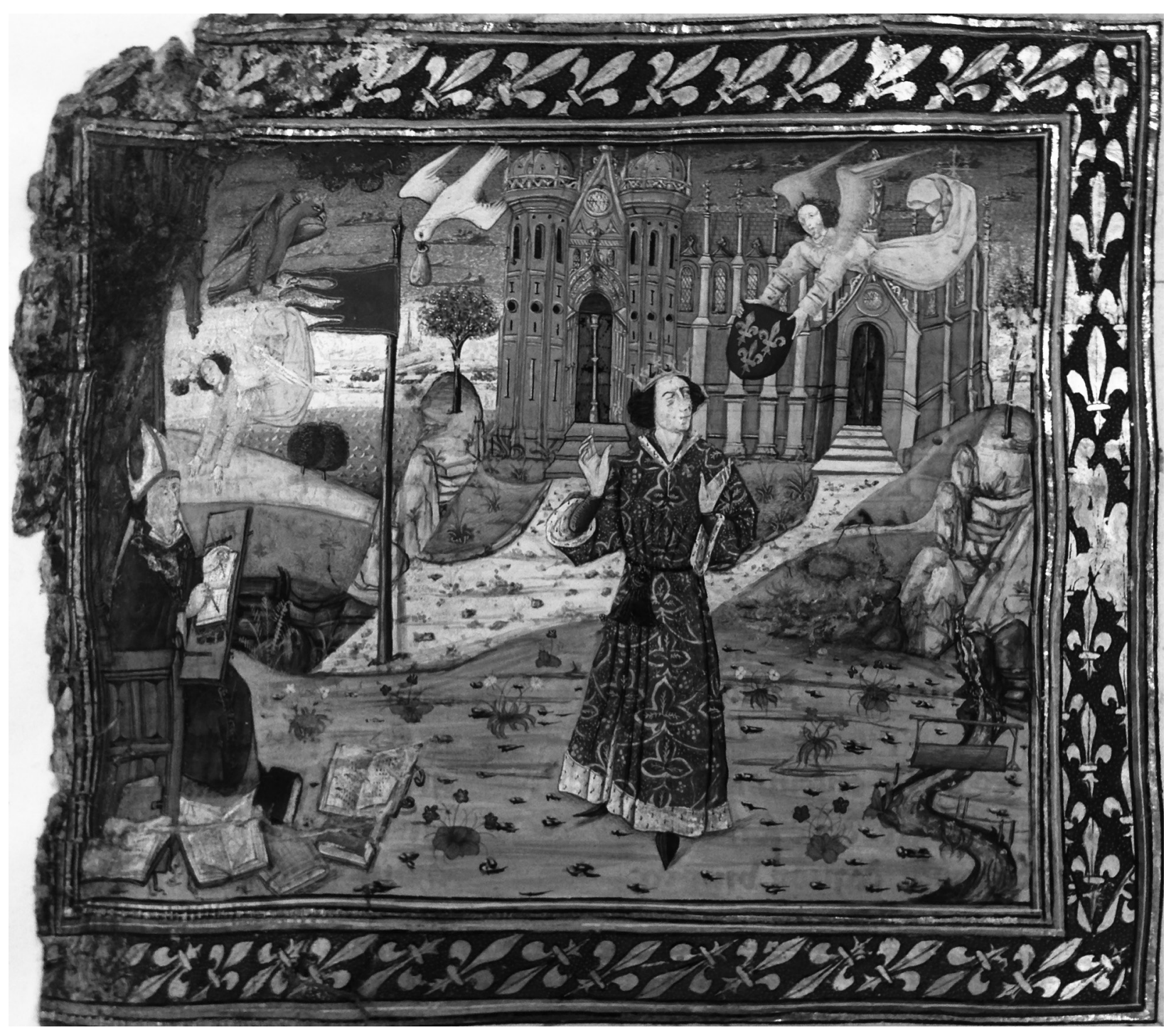

Fig. 28. Saint Augustine and Clovis I, Saint Augustine: Cité de Dieu, vol. 1, c. 1466;

Turin, Biblioteca Nazionale Universitaria di Torino, ms. L I 6, fol. 1r

refer to the use of Tournai, and taking these as her starting point, she connected further manuscripts to this core, based on an analysis of style, and finally attempted to define a general stylistic identity of manuscript painting in Tournai. From these manuscripts, however, it is difficult to pick out any stylistic characteristics that are actually specific to Tournai; the common features mentioned by Komada herself were extremely general in nature, such as the style of drawing and the stiff pleats modelled with gold hatching. ${ }^{97}$ Instead, she sought a common denominator in the secondary decorations and the decorative margins, on the basis of which the Bible historiale in the Beinecke Library and the Turin Cité de Dieu can also be included among the works produced in Tournai. ${ }^{98}$ There are indeed a couple of close similarities - between Beinecke 129 and the Chroniques dites de Baudouin d'Avesnes of The Hague (KB 71 A 14), ${ }^{99}$ for instance, or between the Book of Hours kept at the Simor Library in Esztergom and one in Paris (BnF lat. $13282)^{100}$-, but when the group is taken as a whole, the relationship does not seem to be as strong as Komada presents it.

Although none of the various similarities and analogues would provide strong enough evidence on their own, when seen together, there is quite a high degree of probability that the Master of the Turin Augustine and his workshop were active in the area around Tournai, or perhaps Lille, which also implies that the illuminator of the Gradual 
began his career in the same region. At first sight, it does not seem logical that Komada, who put forward and argued in favour of a Turin localisation, placed the creation of the Gradual in Buda without doubt, what is more, by making reference to the unanimous professional opinion. ${ }^{101}$ Moreover, on the basis of the referenced literature (the works of Erzsébet Soltész), it is not clear exactly what consensus Komada is referring to, for Soltész was one of the most vociferous proponents of the illuminator of the Gradual having foreign origins. To determine whether the Flemish master of the Gradual was present at the Royal Court in Buda in the 1480s, it is necessary to examine the miniature decorating the frontispiece of an incunabulum in Klosterneuburg, attributed to the Master of the Gradual by Sieveking, since this attribution served as the main argument in the literature in favour of the Gradual having been made in Buda. ${ }^{102}$

\section{The Miniature of Saint Leopold from the Augustine-Canonry of Klosterneuburg.}

In his monograph of 1986 on an Austrian illuminator, the Master of the Wolfgang Missal, Hinrich Sieveking attributed the frontispiece miniature of an incunabulum (Cod. Typ. 814, Fig. 29) in the library of Klosterneuburg Monastery to one of the masters of the Gradual (not the Italian one). ${ }^{103}$ The book, entitled Defensorium canonisationis futurae Sancti Leopoldi by Johannes Franciscus de Pavinis, and propagating the canonisation of Leopold III, Margrave of Austria (1073-1136), was published in Rome in 1483, which is therefore the terminus post quem of the miniature. Leopold was canonised in 1485, but the halo around his head seen in the frontispiece does not necessarily imply that the painting was made after this; it may have preceded the canonisation of the Margrave, and this seems more likely, given that it was accompanied by a text in support of Leopold's canonisation. ${ }^{104}$

Franz-Joachim Verspohl, in his study of 2000, was the first to substantiate this attribution using observations of style. ${ }^{105}$ Although later research has unanimously accepted the identity of the illuminator, it is worthwhile reviewing and re-evaluating the stylistic arguments in support of this attribution, for the miniature of
Saint Leopold is of key importance in determining the circumstances surrounding the creation of the Gradual of King Matthias, in particular the place where it was decorated. As asserted by Verspohl, the facial type of Leopold, with its highly raised, arched eyebrows, its thick lower lip and its two-pronged beard, is perfectly compliant with the figures in the Gradual that portray elderly men. ${ }^{106}$ Verspohl was also correct with regard to the posture of the saint: this graceful, slightly effete, though imperfect contrapposto is echoed in certain soldiers in the Gradual (such as the armoured soldier on the right in fol. 103r [Fig. 32] and the knight on the left in the background of fol. 95r [Fig. 11). Here too can be seen the slightly buckled, outward-pointing knees and the out-turned feet, one of which - the one resting forward - touches the ground only by the toes.

Even more characteristic than the rather customary facial type used for old men and the leg posture, which also appears in other manuscripts, ${ }^{107}$ is the portrayal of the scenery. The conical cliffs, broken into horizontal layers by drawn lines that envelop them like a belt, are particularly distinctive. The same kinds of formations can be seen on several pages of the Gradual, such as fols. 37r and 95r (Figs. 3, 11), and in a somewhat more complex form, piled together, in almost every scene that is set in a landscape. (Fig. 30) The regular geometric, rounded trees in the midground and the more sparsely leaved trees in the foreground, with foliage that clusters together at the ends of the widely spaced-out branches, can also be found in the repertoire of the Gradual (fols. 115v, 111r). The horizon is also painted in a similar way, with dark-blue dots of trees lined up like a string of beads along light-blue, barely apparent mountain ranges (Fig. 1 and fols. 86r, 115v, 180r). The miniature of Saint Leopold of Klosterneuburg can therefore be attributed to the Master of the Gradual of King Matthias with a great degree of certainty.

More problematic is the question of the marginal decoration, and Verspohl's assertion that the decorative borders of the miniature of Klosterneuburg are "approximately identical" to those on the frontispiece of the Gradual seems rather exaggerated. ${ }^{108}$ (Figs. 1, 29) There is no doubt that a number of motifs are common to both borders: the strawberry and bramble, the blue campanula, and the pink thistle. However, the branch 


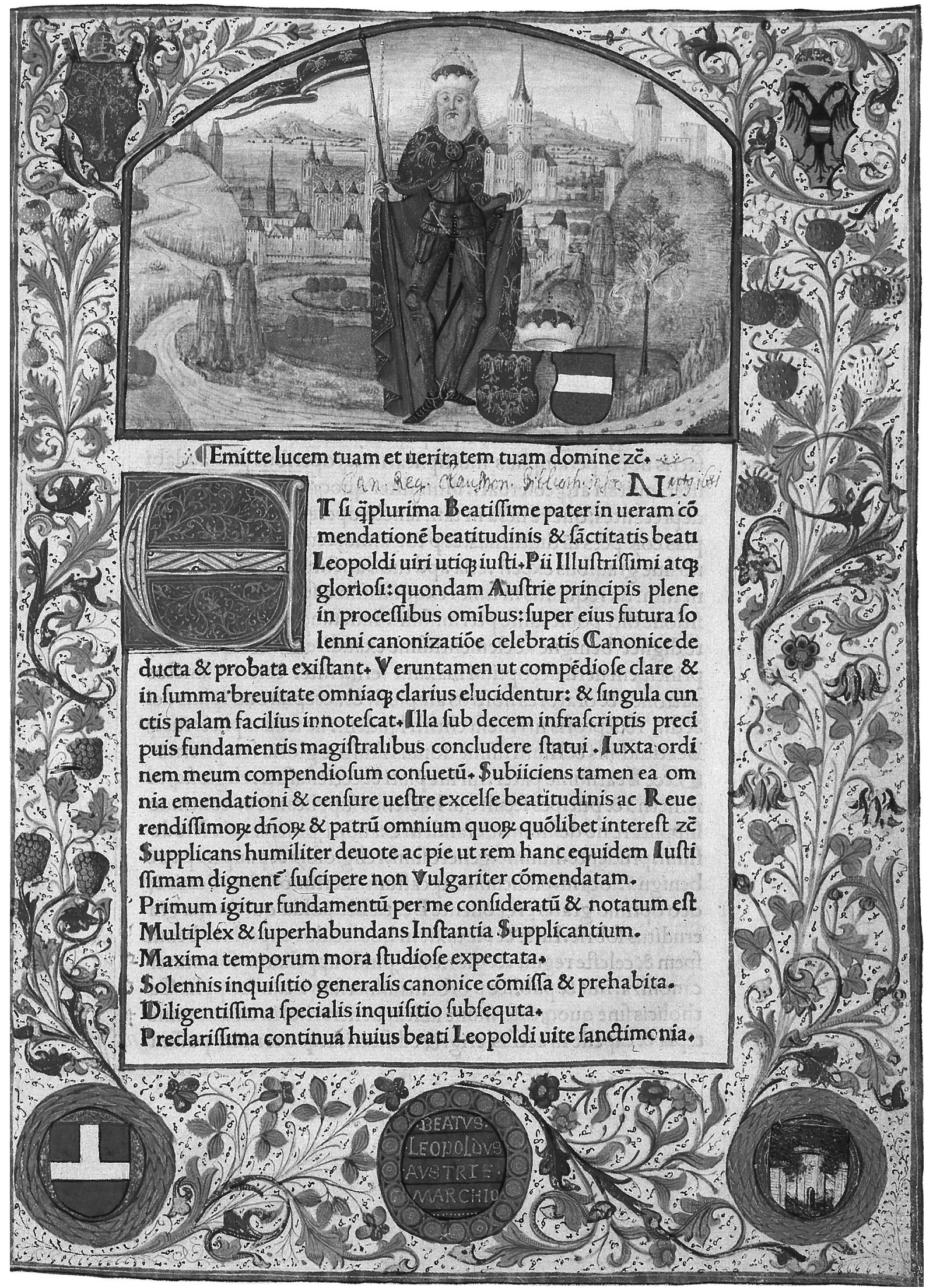

Fig. 29. Frontispiece, Johannes Franciscus de Pavinis: Defensorium canonisationis futurae Sancti Leopoldi; Klosterneuburg, Augustine-Canonry, Library, Cod. Typ. 814, fol. 2r 
motif and the drôleries that populate the tendrils of the plants, which are quite distinctive features of the Gradual, are not present at all in the frontispiece of the Klosterneuburg incunabulum. There is also none of the illusionistic effect, one of the most unique features of the border in the Budapest manuscript, achieved by placing threedimensional motifs on a grey base. The marginal decoration on the incunabulum's frontispiece nevertheless belongs to the Franco-Flemish style, and it is not the work of the same Italian master who produced the other two illuminated copies, as stated in the exhibition catalogue titled Der Heilige Leopold and, in its wake, by Alois Haidinger. ${ }^{109}$ The copy of Cardinal Francesco Piccolomini, now in the Vatican, was undoubtedly decorated by an Italian illuminator, and based on its identical composition and its Roman Quattrocento binding, the book in Vienna, once owned by Frederick III (1415-1493) was also probably painted by an Italian. ${ }^{110}$ By comparing the details of form, it is also conceivable that the marginal decoration of the incunabulum, and not only the portrayal of Saint Leopold, was also made by the Master of the Gradual (and not simply by somebody with the same origins). The basic shape of the acanthus tendrils - consisting of longer leaves that extend, funnel-like, from narrow, extended stems, and of suddenly protruding smaller, fleshier leaves arranged in lobes - is very similar in both manuscripts, even though the differences in the forms (complexity, modelling and attention to detail) would seem, at first sight, to place the two marginal decorations quite far apart from each other. The dots along the veins of the lobed leaves are also identical, as are the number of leaves on the calendula, the shape of the flowers, and the colouring of the petals, divided lengthwise to generate a three-dimensional effect.

The question arises of how this leaf relates to the earlier group of works localised to the area around Tournai or Lille. Although there is no complete match in any respect, it is not hard to find similar faces to that of Saint Leopold on the pages of the Cité de Dieu, the Bible historiale and the London Book of Hours. (Figs. 5, 10, 21) For the scenery, which is more relevant than the image of Leopold from a style analysis point of view, analogues can also be found, particularly in the Cité de Dieu: the landscape is significantly divided, and conical formations of rocks, similar to those in the Klosterneuburg picture, are also present. (Figs. 5, 18) All that is missing is the distinctive motif of the blue trees lined up across the mountains on the horizon. Among the decorative borders, however, apart from the least specific motifs, there is no similarity at all, but this is true for the entire group of manuscripts: none of the marginal decorations in any of them matches that of any other to the extent that they could be attributed to the same person. (Figs. 14, 20) This, however, as we have already mentioned, can be easily explained by the fact that the task of secondary decoration was often allocated to someone different from the illuminator who was responsible for painting the illustrations.

The connection between the incunabulum of Klosterneuburg and the works that can be localised to the Netherlands therefore seems to be looser than the one with the Gradual, but there could be various reasons for this. Firstly, the miniature of Klosterneuburg provides relatively few details on which to base comparisons, while the portrayal of the scenery in the Gradual, which is the main support for Sieveking's attribution, shows the greatest degree of development compared with the earlier, Flemish manuscripts. Secondly, stylistic dissimilarities are to be expected after approximately a decade and a half of time, compounded by about 1000 kilometres of separation, and certain differences in the type of task, the scale, and the level of sophistication. Thirdly, if we look upon the relationship between the Master of the Turin Augustine and the illuminator of the Gradual as one of master and pupil, then we have no true grounds for dissatisfaction with this looser connection.

There is also an aberration in the heraldry that argues in favour of the illuminator having foreign origins: on the mantle of Saint Leopold and on his coat of arms, the eagle of the Babenberg dynasty has, quite erroneously, been given a double head, perhaps under the influence of the imperial eagle that is depicted in the topright corner. (Fig. 29) It is highly unlikely that an illuminator from Vienna, or from elsewhere in Central Europe, would have committed such a mistake. ${ }^{111}$ This error has echoes in some of the oddities of the coat of arms of King Matthias in the Gradual. (Fig. 31) It was already observed by earlier researchers that the lion in the fourth quarter is red upon a silver field, that is, the lion of Beszterce, although after the title of Czech king 
was obtained in 1469 , it was customary to use the Czech lion, whose colours are the reverse, that is, silver on a red background. ${ }^{112}$ Even as a lion of Beszterce there are further mistakes, for it is supposed to have just one tail, whereas in the Gradual, despite the fact that the red paint can hardly be seen from the heavily oxidated silver, it is clear that the animal has two tails, as though it were a Cizech lion. The illuminator therefore either confused the colours of the lion, or the number of tails, although in any case his knowledge of local heraldry was deficient, as evidenced by the double head of the Babenberg eagle. All this is easily explained if the illuminator came from a foreign land.

If all the above is accepted, then the Flemishstyle miniatures of the Gradual were painted by a Flemish master, who probably learned his craft in Tournai or Lille, and who somehow came to Central Europe in the 1480s, passing through Vienna after 1483 to paint at least one miniature. There are several points of argument in favour of his presence in Vienna. In the background of his portrayal of Saint Leopold a faithful reproduction of Vienna's Stephansdom can be seen. Moreover, the iconography of the frontispiece follows that in the copy belonging to Frederick III that was decorated in Italy (therefore independently of the one in Klosterneuburg), in the way Saint Leopold holds the flag in one hand and the model of the monastery in the other, in the arrangement of the coats of arms and the princely hat, and in the laurel wreaths in the border decoration, which are alien to the Flemish style. The suggestion that these works were painted "only" by an illuminator from Buda, who copied models from the Netherlands which have since been lost - a view that has been regularly revived since it was first proposed by Edith Hoffmann, up to and including the latest publications by Gyöngyi Török -, is a position which, in the light of the foregoing arguments, I no longer regard as tenable. ${ }^{113}$

\section{The Question of different "Hands" within the Gradual}

The illuminator's migration from the Tournai region to Vienna (and perhaps to Buda) helps to answer the question of the kind of workshop structure that lay behind the painting of the Gradual. In the earlier literature, the recurring assumption - which is based on the large number of miniatures and their fluctuating quality - is that an assistant collaborated with the master in carrying out the work. ${ }^{114}$ It is not very likely that the Flemish illuminator came to Central Europe with his workshop in tow, however. Jonathan J. G. Alexander also assumed that when Francesco da Castello came from Milan to Buda, he arrived alone. ${ }^{115} \mathrm{I}$ also find it hard to imagine that during his sojourn in this region, the master would have had time to train an apprentice who could imitate his style so perfectly. The probability of this is further diminished by the fact that, apart from some similar motifs in the Vatican Missal, there are no further instances of his influence anywhere else in Vienna or Buda. ${ }^{116}$

Meanwhile, a closer inspection of the miniatures in the Gradual also fails to provide justification for distinguishing between different hands: the same types of figures and faces constantly recur, and the same approach to the landscape is followed throughout the manuscript, accompanied all the way through by the same lack of assurance in conveying the perspective of buildings. Ilona Berkovits attributed the first few miniatures to the leading master, which are surrounded by initials in grisaille that imitate architecture with sculptural decoration. ${ }^{117}$ (Figs. 2, 4) The fact that the other decorations are executed with comparatively less attention does not necessarily imply the collaboration of an assistant. Erzsébet Soltész convincingly ascribed the reduction in quality to a lack of time, pointing out the gradual diminution of complexity in the initials (sculptural imitation is omitted from fol. $17 r$, although the letter constructed in imitation of openwork tracery still gives the illusion of three-dimensionality; later, however, the illuminator only painted letters with two-dimensional ornamentation [Fig. 30]). ${ }^{118}$ The presence or absence of anatomical precision, which Soltész attempted to take as the basis for separating the work of the master and his apprentice, cannot be used to distinguish between the hands either. The purported qualitative difference between the figures of the money exchanger and the goldsmith (Fig. 32), which Soltész gives as an example, is not so evident, for both figures have slumped shoulders and unnatural pos- 


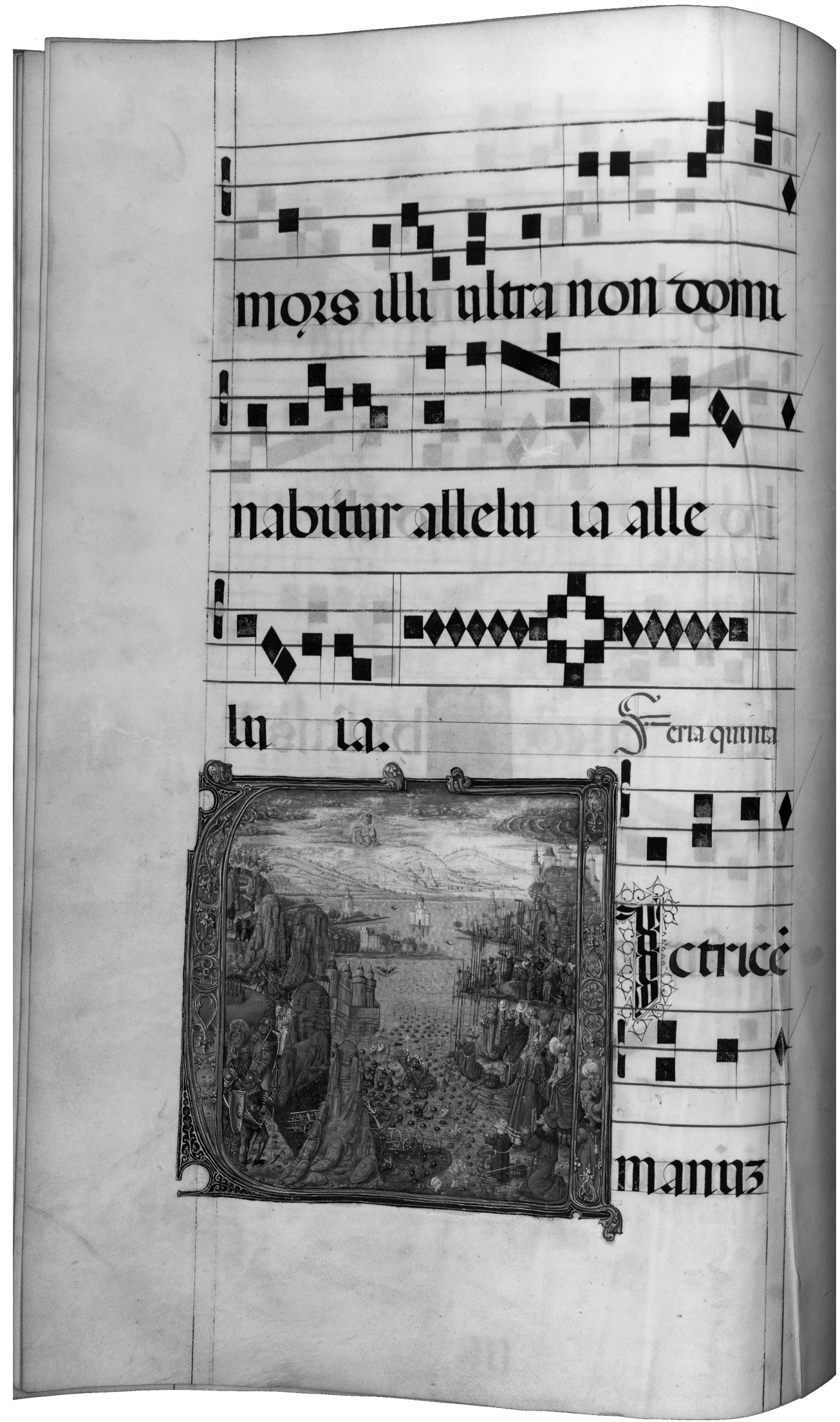

Fig. 30. Initial ' $\mathrm{U}$ ' / The Crossing of the Red Sea, Gradual of King Matthias, 1480s: Budapest, National Széchényi Library, Department of Manuscripts, Cod. lat. 424, fol. 17v 
tures. Inexpertly drawn anatomical details and postures are also to be found even in the best generally executed miniatures: in fol. 10r, for example, the neck and shoulders of the figure in the turban are joined somewhat awkwardly, while on the kneeling figure in the foreground, the arm pouring water is also poorly drawn. (Fig. 2) Within the Gradual, therefore, there is no stylistic split that would imply the division of the work, and the minor qualitative discrepancies can be satisfactorily ascribed to external circumstances.

Among the works the illuminator made in Central Europe, it is perhaps only the reconciliation of the marginal decorations in the Gradual and on the miniature of Klosterneuburg that causes certain problems, although the similarity between the details of form, outlined above, does enable us to interpret the qualitative fluctuations within one œuvre. The reason for the differences may have been the lower prestige of the commission, the smaller amount of payment, or even the fact that the border in the precedent was of similar quality.

The attribution of the miniature of Klosterneuburg adds a further dimension to the question of where the Gradual was created, for it raises the possibility that the manuscript was painted by the Flemish illuminator not in Buda but in Vienna. It is also conceivable that the Flemish illuminator brought the still unfinished manuscript with him from the Netherlands, and the Northern Italian-style miniature was added to the choir book later, when it was in Buda. In order to rule out the latter possibility, and to assess the matter of Buda versus Vienna, it is necessary to examine the script of the Gradual as well as the Northern Italian-style miniature.

\section{THE SCRIPT}

The precise definition of the script type used in the Gradual of King Matthias (scriptura gotica textualis formata rotunda) first appears in the 1963 study by Kilián Szigeti, who also first used this as an argument for determining the place where the Gradual was made. ${ }^{119}$ The rotunda script is a southern, or more precisely, in the case of the Gradual, an Italian variant of the textualis. Its main characteristics are the rounded curves, which can be seen most clearly in the letters $b, c$, $d, e, h, p, q$ and the round $s$. This roundedness results in the letters being concomitantly wider, as opposed to the verticality of the northern textualis. The vertical stems - apart from in the script of university books, called littera bononiensis - are usually proportionately long, with ends that are undecorated or almost imperceptibly decorated. Similarly to textus praescissus, the stems and feet of the letters rest straight on the baseline - this concerns the vertical stems of the $f$ and $h$, the first minim of the $n$ and the first two minims of the $m$, and the straight $r$ and $s$. Further features that distinguish the stems of this script from those of the northern variant are the omission of the artificial spurs and the rarity of decorative hairlines, which appear, at most, in the letters $r$ and $t$. Among the individual letters, it is important to highlight the $a$ and the $d$. The former consists of a single minim, and the almost triangular lobe is made up of a short diagonal stroke and a diagonal hairline in the opposite direction. Two types of letter $d$ are used - the straight, Half-Uncial, and the Uncial $d$ which has a shape that differs strikingly from the northern variant, with the shaft, which is generally rather short, connected horizontally to the lobe of the letter. ${ }^{120}$ All these features, without exception, are found in the script of the Gradual. Here, the calligraphy of the rotunda script is in its most meticulous and ceremonial form, the textualis formata, which was used from the mid-fifteenth century in liturgical books and in books of hours. ${ }^{121}$ The question concerns the extent to which the rotunda type facilitates a precise localisation.

While there is no doubt that this type of script was used primarily in southern parts of Europe (not only Italy, but also Spain and Southern France), ${ }^{122}$ by the end of the fifteenth century it had spread beyond these regions. Reasons for this included the distribution across all Europe of mostly legal manuscripts written in littera bononiensis, the geographical proximity of Italy, the cultural, political and commercial ties, and the spread of printed books that used the rotunda script. ${ }^{123}$ Under these influences, it was also used at the end of the fifteenth and the beginning of 


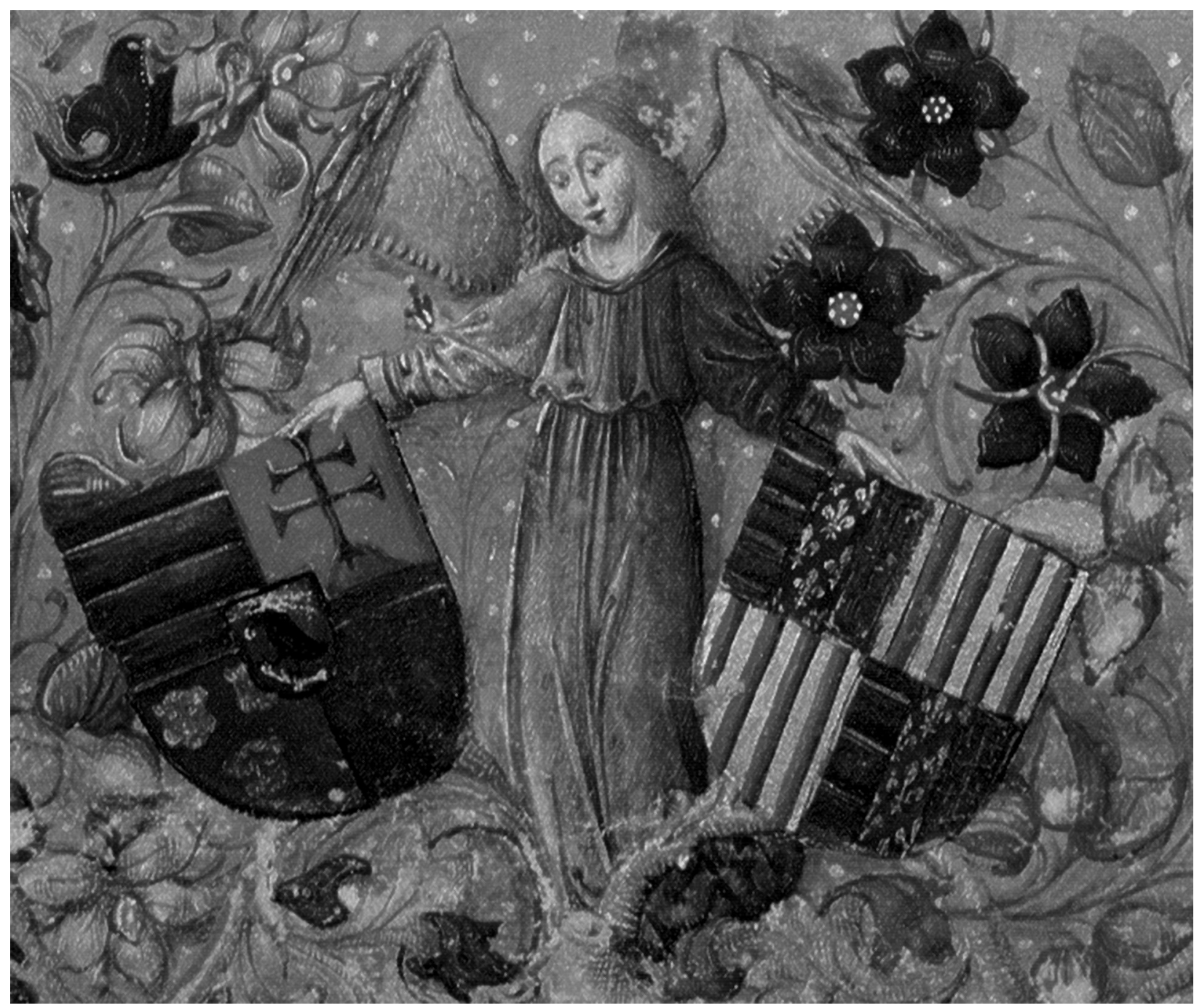

Fig. 31. Coats of Arms of King Matthias and Queen Beatrice of Aragon, detail of fig. 1

the sixteenth centuries to write books of hours and breviaries in, among other places, the Netherlands. Several books of hours illustrated by the Master of the Dresden Prayer Book were written in this script between the 1470s and the first decade of the sixteenth century, ${ }^{124}$ and the same script also appears in a few books of hours from the 1460s that are associated with the workshop of Willem Vrelant. ${ }^{125}$ Its use became even more common in the $1500 \mathrm{~s}$, such as in the prayer books illustrated by Simon Bening. ${ }^{126}$ Commissions from Italy, Spain and Portugal would also have encouraged the use of this script: a significant proportion of the manuscripts from this time whose provenance is known were made for clients from these parts of Europe. ${ }^{127}$

In the opinion of Derolez, scribes from the Netherlands tend to give away their ori- gins through the angularity of their letters and through their use of spurs that were alien to the Italian rotunda script. ${ }^{128}$ It is of course also possible that Italian scribes were at work in the Netherlands in the second half of the fifteenth century. The only instance of this to which a name can be attached is that of Francesco Florio, who was present in Bruges between 1469 and 1474 . and who probably originated from Arezzo. ${ }^{129}$ It would seem, however, that the main profile of this Italian scribe while he lived in Bruges was to make copies of works by classical authors, for which he employed a humanist script. ${ }^{130}$

Derolez refers to liturgical books in general as the "field" in which rotunda was used, but I have not yet come across this script type in any Flemish choir book, and it would appear that manuscripts for private devotion, such as books 
of hours and breviaries, far more commonly featured the rotunda script. A contribution to this may have been played by a kind of conservatism and respect for tradition, which derived perhaps from the genre of the choir book, from the clients themselves, who consisted predominantly of monastic communities, abbeys and other ecclesiastical institutions, or perhaps from the scribes being monks. ${ }^{131}$ On this basis, it can be ascertained with certainty that while rotunda was known and used in the Netherlands, it was rarely handled with as much refinement and purity as it was in the Gradual, in addition to which choir books continued to use the northern, more angular textualis type, which implies that the Budapest manuscript was probably not copied here.

From the end of the fifteenth century, a large proportion of the liturgical books made in Hungary, including choir books, were written in rotunda script, including the books of Domonkos Kálmáncsehi (d. 1501, Provost of Székesfehérvár, later Bishop of Oradea), the Pontifical of Bishop János (John) Filipec (1431-1509), the Vatican Missal of King Matthias, and, among choir books, the Buda Antiphonary, the Bakócz Gradual and the Franciscan Gradual of Lippa. ${ }^{132}$ Judging from the script alone, it is therefore not inconceivable that the Gradual of King Matthias was copied in Hungary. This was the view taken by Kilián Szigeti in his publications of 1963 and 1969. In the first study, he attributed both the script and the musical notes to a Franciscan scribe, although in the later article he separated them, now asserting that only the neumes were certainly the work of a Franciscan monk, and positing that the text of the choir book may have been copied by the same Martinus Antonius who signed his name in the Brussels Missal that was illustrated by Attavente. ${ }^{133}$ However, the basis on which Martinus Antonius is supposed to have operated in Buda, the expression in his signature that reads "exemplaribus satis fidis," is extremely precarious. It is far more likely that this is a trope-like turn of phrase, rather than an excuse given by the scribe for the quality of the models available in Buda, which in Szigeti's opinion could never have occurred in Florence. Quite the contrary, because of the Florentine execution of the miniature decoration, it is logical to localise the copying here as well. Albinia de la Mare also considered Martinus Antonius to be a scribe from Florence. ${ }^{134}$
Szigeti was, however, irrefutably correct in stating - as was later confirmed by the research of Janka Szendrei - that square musical notation was first used in Hungary by Franciscan and Dominican monks (examples include the Franciscan Gradual of Lippa, the Franciscan Antiphonary now in Güssing, and the Dominican Diurnal in Sighişoara). ${ }^{135}$ The conventional musical notation in the prestigious, ornamental choir books of the laity and royalty was a mixture of Metz-Gothic and Hungarian, the use of which, in the opinion of Janka Szendrei, was led by humanist prelates and even King Matthias himself. ${ }^{136}$ However, the examples that are put forward - the Bakócz Gradual, the Zalka Antiphonary, the Gradual of King Vladislav, and the Zagreb manuscripts of Osvát (Osvald) Thuz $^{137}$ - do not entirely clarify what kind of role was played by Matthias, and as far as I am aware, this type of notation does not feature in any of the manuscripts belonging to Matthias. In the Vatican Missal that was illuminated in Buda, on the pages containing music, the musical notes were not inserted above the text of the Exultet $(81 v-86 r)$. The fact that the use of square notation was restricted in Hungary to Franciscan (and Dominican) manuscripts was part of the reason why Kilián Szigeti put forward the idea that at least the musical notes were written into the Gradual in a Franciscan scriptorium. ${ }^{138}$ In the course of her research, however, Janka Szendrei came to the conclusion that, "judging by all the signs," the Gradual must have been copied by a foreign master, or at least by one who had been trained abroad, because there is no other example in Hungarian manuscripts of such a regular, stylised form of square musical notation. ${ }^{139}$

If there were any manuscripts copied in Hungary whose script was close enough to the one used in the Gradual of King Matthias, this might warrant the conclusion that the Gradual was also copied in Hungary (comparisons can most ideally be made with choir books whose script is of a similar size); as there are no such manuscripts, at least to the best of my present knowledge, it is worth considering the suggestion put forward by Janka Szendrei concerning a foreign master. The above outline of the use of rotunda script and the qualities of the lettering used in the Gradual would almost certainly narrow down the word "foreign" to mean "Italian." 


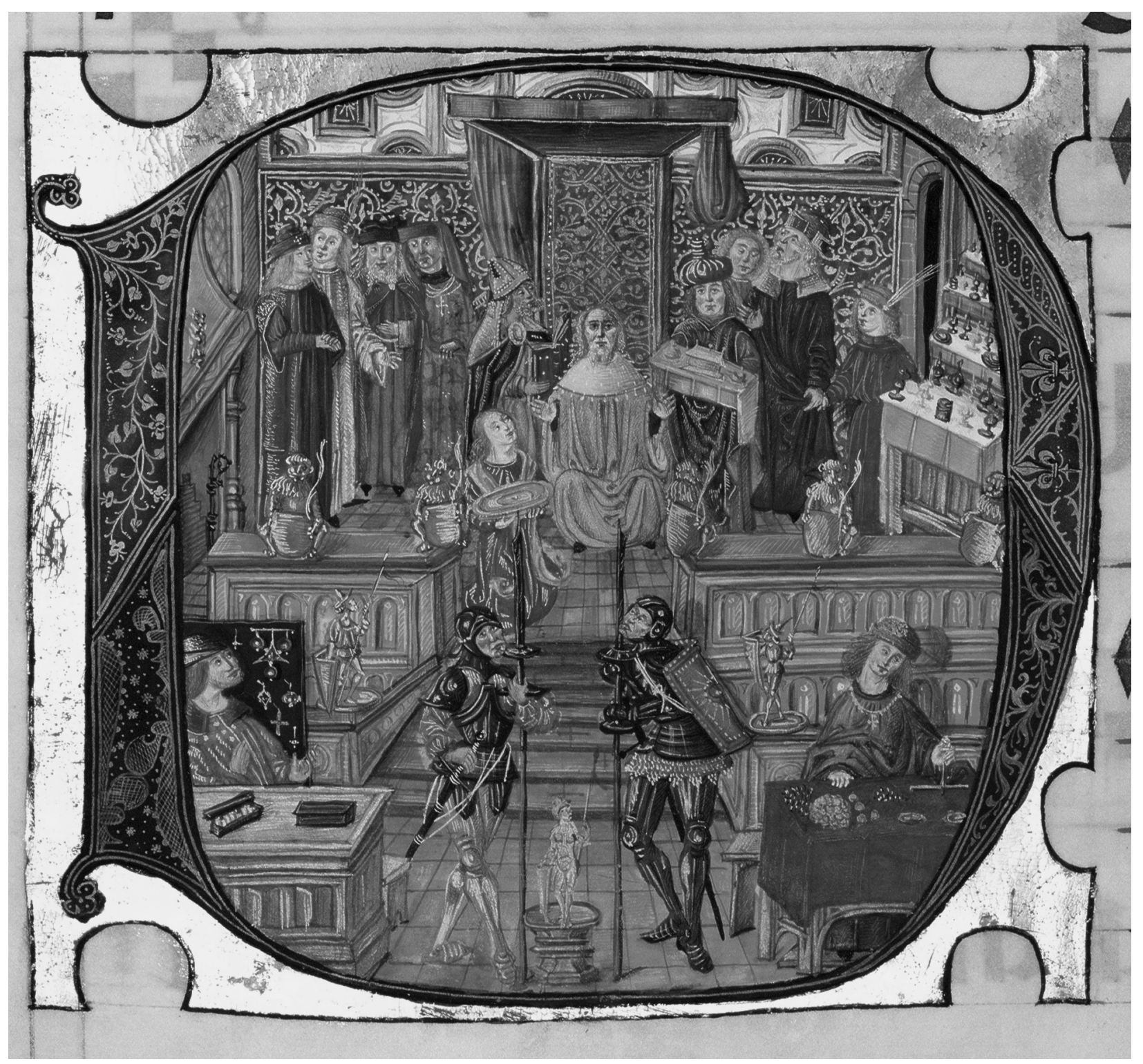

Fig. 32. Initial 'D' / Court of King David, Gradual of King Matthias, 1480s;

Budapest, National Széchényi Library, Department of Manuscripts, Cod. lat. 424, fol. 103r

The idea of a scribe of Italian origin may be supported by comparison with the script of a group of liturgical manuscripts from Lodi Cathedral in Northern Italy. These choir books, which are presently distributed half and half between Lodi Municipal Library and the Pierpont Morgan Library in New York, were given to the Cathedral of San Bassano by Carlo Pallavicino, Bishop of Lodi, in 1495, although judging from their style, work on the manuscripts must have begun approximately two decades earlier. ${ }^{140}$ Four of the antiphonaries that are still in Lodi today, as well as the breviary, were worked on in the late $1470 \mathrm{~s}$ (definitely before 1481) by Francesco da Castello, who was also active in Buda. ${ }^{141}$ The two Kyriale manuscripts now in New York were probably added to the series around 1496-97, and they were evidently copied and illustrated by different hands to those who had made the earlier pieces. ${ }^{142}$ In her study of the scriptoria that worked for Carlo Pallavicino, Lisa Longhi, acknowledging that at this level of professionalism, in the absence of sources and signatures, it is extremely difficult to differentiate separate hands simply by "looking at them," could only suggest hypotheses concerning the scribes of the Lodi choir books. Because of the high standards applied in the scriptoria of the monasteries, Longhi posited that the manu- 
scripts were written in a monastic environment, and because of the prominent iconographic and liturgical role played in them by Saint Anthony the Abbot and by Saint Augustine, which is not derived from the Lodi liturgy, she attempted to connect the copying of this group of manuscripts with the scribes of the Congregazione Agostiniana dell'Osservanza della Lombardia. ${ }^{143}$

The relationship between the script of the Lodi choir books and the Gradual of King Matthias is most noticeable in the calligraphic letters (Fig. 33), which often feature penwork decorations, and which, in the Budapest manuscript, tend to be located after the illuminated initials (although there are a few scattered exceptions, such as fol. $2 v$ ). In the Lodi manuscripts, they occur more frequently in other contexts as well. The question, however, concerns how generally widespread these solutions were, and how far the formation of these letters can be characterised according to region, scriptorium or individual scribe.

One of the most striking traits of the calligraphic lettering is the thin penwork decoration that recalls a "thorny berry": the letters are surrounded by small round loops, to each of which are connected three pointed triangles, all drawn with a single, dynamic line. ${ }^{144}$ This tiny decorative component cannot be taken alone as a unique feature, however, as it appears in other Lombard choir books, such as on the frontispiece of an antiphonary made for the Convento degli Eremitani di Sant' Agostino in Cremona. ${ }^{145}$ Work on copying the sequence, which originally consisted of eight volumes, was completed in 1498 by the Augustinian friar Apollonio da Calvisano. ${ }^{146}$ The same type of decoration can be seen in a Lombard antiphonary that is now kept in Budapest (National Széchényi Library, Cod. lat. 133, fol. 30r). Stepping outside of Lombardy, but remaining in Northern Italy, the same motif can be found in works from Ferrara, including a fragment dated to the 1470 s that was sold at auction in Christie's, and an excised leaf now in the Philadelphia Free Library, which is also dated to the third quarter of the fifteenth century. ${ }^{147}$ This decoration cannot even be regarded as specific to the region, because similar examples can also be found in Florence, appearing in choir books from Florence Cathedral that were made in the early sixteenth century. ${ }^{148}$ There are of course discernible, though tiny differences in form among the examples given: in the
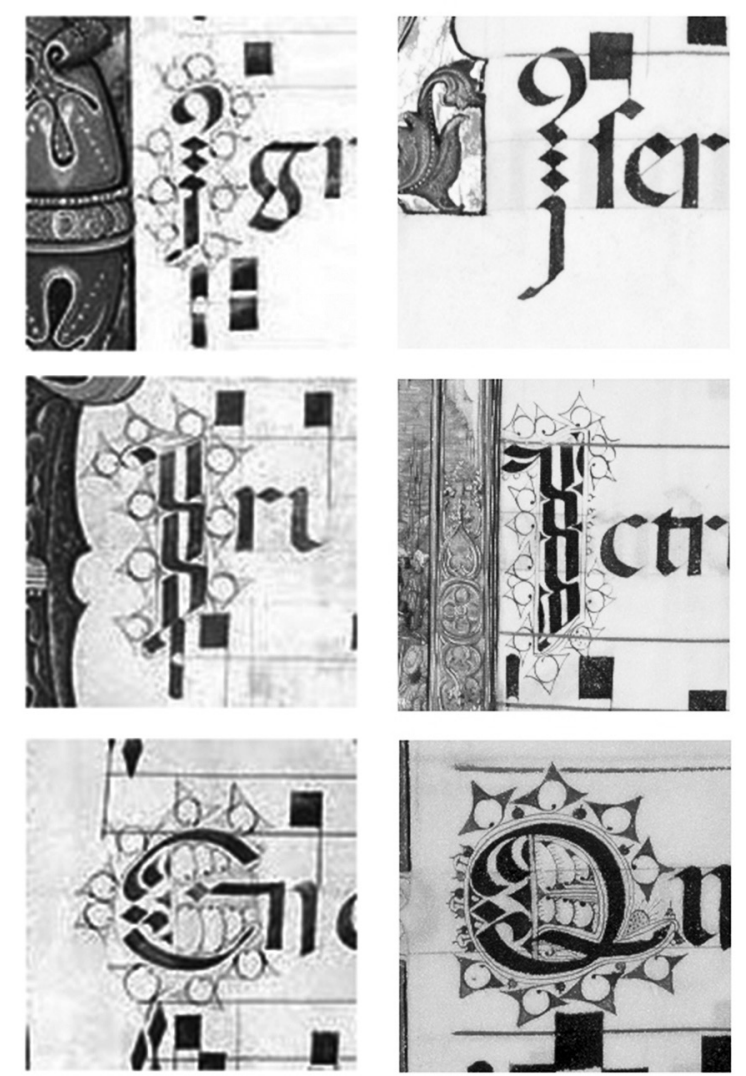

Fig. 33. Initials, on the left from the Antiphonary of the Lodi Cathedral, New York, The Pierpont Morgan Library, ms. M.686, fols. 64v, 128r, and 179r

(Photo: The Pierpont Morgan Library, New York), on the right from the Gradual of King Matthias, 1480s, Budapest,

National Széchényi Library, Department of Manuscripts, Cod. lat. 424, fols. 33v, $17 \mathrm{v}$, and $10 \mathrm{r}$

Florentine works, there are small bumps between the thorns; in the other two Lombard examples and the one from Philadelphia, the thorns are more pointed and more densely distributed. In the Gradual and in the Lodi manuscripts, meanwhile, the lines leading from one triangle to the next are almost straight. Nevertheless, the prevalence of this type of decoration prevents any far-reaching conclusions from being drawn about the origin of the scribe, based on this information alone.

It is more fruitful to compare the shaping of the calligraphic letters themselves, although here too there are certain difficulties. Firstly, there are several variants of equal rank of particular letters in both the Gradual of King Matthias and the Lodi manuscripts, such as the letter $i$. Secondly, in several cases (with the letters $e, a, m$ and $u$ ), the variants used by the scribe in the Gradual are simpler than those in the Lodi manuscripts. In 
spite of this, several points of connection can be identified. Two of the multiple variants of the $i$ can be seen both in the Lodi manuscripts and in the Gradual: the one whose stem recalls two intertwining ribbons, and the one built from a column of rhombuses and topped with a rounded loop. ${ }^{149}$ There is also an almost stroke-by-stroke match between the shapes of the simpler variants of the letters $x, m, a$ and $u$ in Pallavicino's manuscripts and in the Gradual, although in these cases, the simplicity makes them less specific, so they are less valuable as evidence in support of a direct relationship between the two scripts. A far better example is the more intricately and meticulously composed $q$ on fol. 10r of the Gradual, which is closely related to the letters $o, d, e$ and $c$ in the Lodi manuscripts. ${ }^{150}$ Their common characteristic is that the left of the curve of each letter is attached to a small rhombus, with the lower arc of the curve turning inwards, in a largish loop. towards the belly of the letter, while the upper, smaller arc is repeated on the inside with another parallel arc of the same shape. The space between the arcs is filled with a line drawn vertically down within the body of the letter, on which are arranged a tiny segment and two small triangles. In the Lodi manuscripts, this shape, together with its simplified variants, can be observed all the way through, but in the Gradual its only appearance in its full complexity is here, and later in the choir book it only returns in versions that have been simplified to a greater or lesser degree (either the small rhombus is omitted where the two arcs meet, or the space-filling elements are missing). With the letters $o, c$ and $e$, meanwhile, there are many examples of completely modified shapes.

Another point of commonality between the two manuscripts can be found in the shape of the caesura marks that fill out the empty staves at the ends of certain units, where the scribe produces decorative patterns, that are composed from the square and rhomboid elements of the musical notation. ${ }^{151}$ (Fig. 30) While one of the choir books in Florence Cathedral also features such spacefilling decoration, it is in a different form. ${ }^{152}$

The significance of these similarities between the Gradual and the Lodi choir books can be understood by comparing them with the letters used in the San Sisto choir books. These were also made in Lombardy around the same time as the Lodi manuscripts (partly in the 1470s and partly in the 1480s), and Francesco da Castello also carried out some of the work on them. The calligraphic letters, however, are formed in a completely different way, and bear no resemblance at all to the Gradual nor to the Pallavicino manuscripts. ${ }^{153}$

A comparison of the calligraphic letters, then, shows that, while caution is still warranted with regard to what is local and what is individual, the similarities between the Gradual and the Lodi manuscripts allow us to conclude that the Budapest manuscript was copied by a scribe of Northern Italian origin, who perhaps had an even closer connection with the scribe of the Lodi manuscripts. Whether the copying was executed in Buda or in Italy is a question that will have to remain unanswered until further information becomes available.

It is important to note that some parts of the text and musical notation are unfinished. ${ }^{154}$ The rubrics naming the feast davs, and the instructions, are largely missing between fol. 95r and fol. $175 \mathrm{v}$, the rubrics indicating the song type are absent between fol. 139r and, again, fol. 175v. At one point, the notation is also deficient: the neumes were not drawn in above the lyric in the first row of fol. 171v in quire 22. (Fig. 34) Furthermore, careful inspection of the rest of this page and of three others (fols. 172r-v, 175v) reveals that the neumes were written in by a different hand, with less refinement than in the rest of the manuscript. The marks at the end of each row are nowhere near rhomboid, the stems are negligently drawn, the keys at the beginning of the rows are shaped differently, the notes are not straight, and the thin lines marking the two sides of their irregularly rectangular heads stick out at one or both ends. The text on these pages was written by the same hand as in the rest of the Gradual, and moreover, judging from the colour of the ink, it was written continuously, regardless of whether the notation was complete or incomplete. The lines of the staves were probably also all drawn at the same time. There is no way of explaining why the notation was left out of these particular pages, for they do not differ from the others either musically or codicologically. Although all four pages are in the same quire and fols. $171 \mathrm{v}-172 \mathrm{v}$ belong to the same, central bifolio, the neumes on the first page of this bifolio, fol. 171r, were written by the original hand. Meanwhile, fol. 175r is surrounded only by completely finished pages, both 
regarding the bifolia and the bound manuscript. It is difficult to ascertain when the neumes were added to the pages in question, but it seems as though the stems or heads of certain notes spill over onto the ornamental initials, while the last note in the last row of fol. 172r-en is missing one corner, probably in order to avoid covering up the letter $B$ above it. If these observations hold true, the notes must have been added after the initials were illuminated, that is, after the decoration of the manuscript was completed. A further peculiarity of quire 22 is that it is the only place where the preliminary marks showing the place for the neumes, which were subsequently scratched out or painted over, are still visible. At present, it is hard to provide a satisfactory explanation for these unique features of quire 22 , although it does seem logical to conclude that this was the last quire to be completed, because the part of the manuscript that follows directly is complete in every way, and from fol. 176r to the end, none of the rubrics are missing, and the penwork decorations of the calligraphic letters are also present.

It is also possible that the state of incompletion came about due to the unbound quires being transported from Italy to Hungary in haste, meaning that the scribe was not around when the missing musical notation had to be supplemented. An example of an unilluminated manuscript from Italy being brought to Buda may be provided by the Cassian Corvina, now in Paris, which was copied by Pierre de Bordeaux in Naples, from where it was probably taken to Buda in 1484 by John of Aragon (d. 1485), Archbishop of Esztergom and brother of Queen Beatrice. ${ }^{155}$ This is by no means the only possible scenario, of course, and the work may just as easily have been left uncompleted if the manuscript was copied in Buda. From this a further question emerges: how much new light can the possibility that the scribe came from North Italy cast on the only Northern Italian-style miniature in the Gradual?

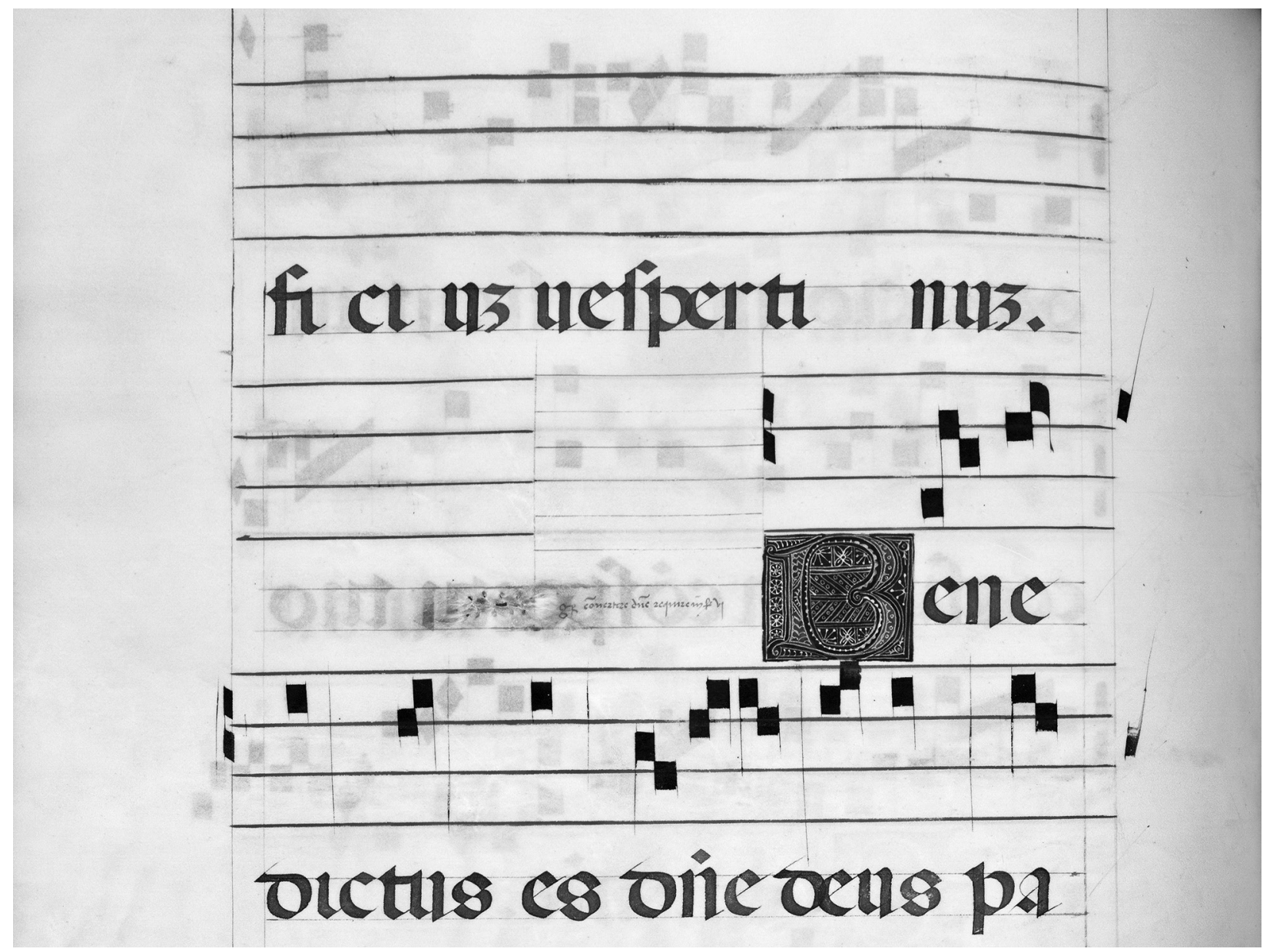

Fig. 34. Unfinished notation, Gradual of King Matthias, 1480s,

Budapest, National Széchényi Library, Department of Manuscripts, Cod. lat. 424, fol. 171v 


\section{THE NORTHERN ITALIAN-STYLE MINIATURE IN THE GRADUAL}

The miniature on fol. $7 \mathrm{r}$ of the Gradual, the scene of The Israelites Entering the Promised Land, together with the four smaller ornamental initials on fol. 1r, were separated by scholars from the other decorations in the manuscript at a very early stage of research by virtue of their style, and they were attributed to a master trained in Italy. ${ }^{156}$ (Fig. 35) In the absence of relevant stylistic analogues, it is unfortunately not possible at present to localise the Italian origins more precisely than by indicating certain regions. Proposals and conclusions have come about primarily from the connection between the miniature and manuscript production in Buda.

\section{Giovanni Antonio Cattaneo da Mediolano}

Two illuminators from Northern Italy who worked in Buda are known to us by name: Francesco da Castello, who signed his name on the breviary of Domonkos Kálmáncsehi, ${ }^{157}$ and Giovanni Antonio Cattaneo da Mediolano. The style of The Israelites Entering the Promised Land - whose figures step daintily, almost like dancers, and in which the drapery has the texture of damp clothing, the pleats and folds are serpentine, and the faces are regular, with long, straight or slightly down-turned noses - can be clearly distinguished from the works of Francesco da Castello. It was therefore not by chance that, at an early stage of research, this miniature was associated with the only other Lombard illuminator active in Buda whose name is known from the written sources: Giovanni Antonio Cattaneo da Mediolano. The Dominican friar arrived in Hungary in 1482 from a monastery in Ferrara, he was appointed Abbot of Madocsa; and in the ledger of accounts of 1495 of King Vladislav II, he is described as "illuminator librorum regiorum."158 His activity as an illuminator of books - which was questioned by Csapodi, who interpreted the above phrase as illuminator of the "royal regesta" - was confirmed by the contracts published by Marubbi, which show that in 1473 he accepted three apprentices into his workshop to learn the craft of illumination. ${ }^{159}$ The idea that he might have been the painter of the North Italian miniature in the Gradual was first proposed by Ilona Berkovits. The twin basis of this bold attribution was, on the one hand, the hooded figure standing on the far right of the leaf, who is portrayed frontally and who has the appearance of a monk, whom Berkovits interpreted as a self-portrait of the illuminator, and on the other hand, the letter $A$ that can be made out among the barely decipherable marks on the back of the banderole that winds around the arm of Joshua, which she deemed to be the monogram of master "Antonius." 160 The figure in the cowl, who prompted the idea of a concealed self-portrait, is indeed not looking out at the viewer, but rather at the figure opposite him, who has his back to us. Hungarian researchers did not adopt this identification, although further - similarly unconvincing - ideas have appeared regarding the identity of the illuminator who was also the Abbot of Madocsa: Jolán Balogh, for instance, claimed that he may have been the Master of the Cassian. Recently, however, the idea that Giovanni Antonio Cattaneo may have been the Northern Italian illuminator of the Gradual was revived by Mario Marubbi, though naturally without following Berkovits's far-fetched interpretation of the self-portrait and signature. ${ }^{161}$ In the absence of works that can be definitively attributed to Giovanni Antonio Cattaneo, or of any detailed written sources, this attribution must remain, for the present, a hypothesis.

\section{The Link between Queen Beatrice's Psalter and fol. $7 \mathrm{r}$}

For many decades, researchers believed the Lombard miniature in the Gradual to be without analogies, and it is referred to as such in the 2003 paper by Tünde Wehli and Mario Marubbi. ${ }^{162}$ In 2010, however, Árpád Mikó managed to find certain initials that are stylistically very similar in Queen Beatrice's Psalter, now kept in Wolfenbüttel. $^{163}$ (Fig. 36) The initials in the Psalter are linked to the miniature in the Gradual partly by the ornamental decoration, in particular the cornucopia motif, from which clusters of green or blue leaves emerge, and partly because the figures are also similarly formed: the geometrically precise yet varied forms of the hats, the longish, 


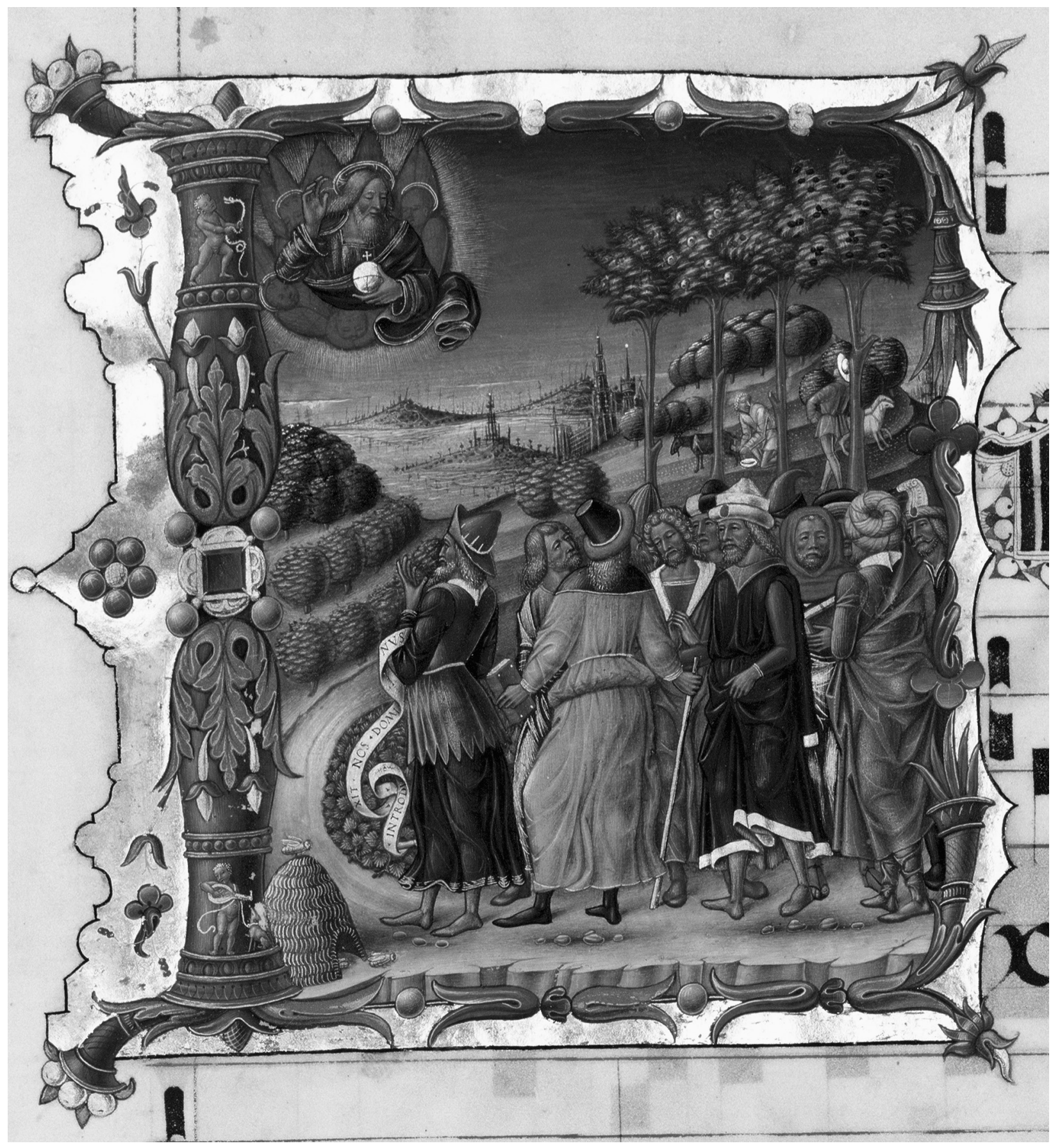

Fig. 35. Initial 'T' / The Israelites Entering the Promised Land, Gradual of King Matthias, 1480s; Budapest, National Széchényi Library, Department of Manuscripts, Cod. lat. 424, fol. 7r

regular faces with their straight or only slightly curving, long noses, the sharply drawn lines of the evelids and brows, and the softness of the beards, conveyed by the muddle of short, thin strokes of yellow or white. The affinities are further enhanced by the domination of pure, cold blues and greens. ${ }^{164}$ Although Árpád Mikó, despite these similarities (but perhaps because of qualitative differences), refrained from equating the illuminator of the Gradual with the painter of the Northern Italian miniatures in the Psalter, it may not be too much of a risk to attribute the works to the same master. This less strict approach to attribution, which ascribes minor discrepancies in quality to differences in size, importance and the available time, and which was applied by Jonathan J. G. Alexander in the case of Francesco da Castello, ${ }^{165}$ may, in my opin- 


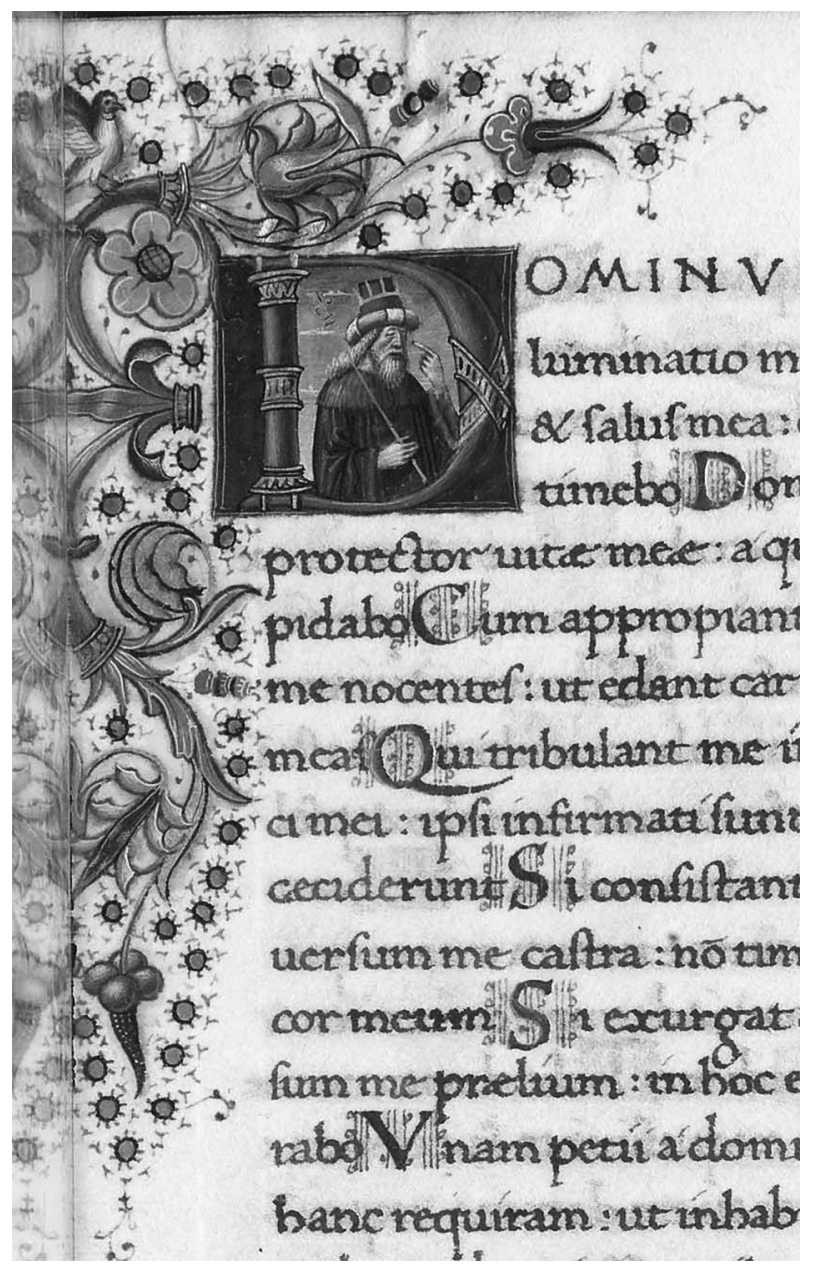

Fig. 36. Initial 'D', Psalter of Queen Beatrcie of Aragon, 1476-1481; Wolfenbüttel, Herzog August Bibliothek,

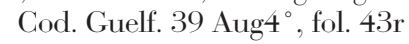

(C) Herzog August Bibliothek Wolfenbüttel

http://diglib.hab.de/?db=mss\&list $=$ ms\&id=39-aug-4f

ion, be worth employing in this case as well. Compared with the impressive size of the scene of The Israelites Entering the Promised Land $(15 \times 15$ $\mathrm{cm})$, the initials in the Psalter measure no more than $2 \times 2.5 \mathrm{~cm}$, and the faces are approximately only half as large in the latter as they are in the Gradual miniature. The relatively lower quality of the initials in the Psalter may have arisen from their less prominent position in the internal hierarchy of the manuscript, which is immediately obvious when compared with the lavishly decorated frontispiece produced by the Florentine Francesco Rosselli. Incidentally, it must not be forgotten how little chance there would have been of an illuminator from Italy settling in Buda with his own fully staffed workshop, or of another illuminator being able to learn his style of painting so accurately within a short period of time.
All in all, the above information persuades me to assume that the miniature in the Gradual and the Northern Italian initials in the Psalter were all probably made by the same hand.

At first sight, it would appear that the Psalter, which was copied by an Italian scribe and decorated by Italian illuminators (from Florence or Northern Italy), does not provide us with a clear answer to the question of whether the scene of The Israelites Entering the Promised Land was painted into the Gradual, which was presumably also copied by a scribe who came from or had studied in Northern Italy, in Buda or elsewhere. To decide on this matter, it is necessary to make a brief detour into the circumstances under which the Psalter was made. ${ }^{166}$

The manuscript is the work of a Florentine scribe named Gundisalvus Hispanus, whose activity as a scribe very probably came to an end in 1478, when he was appointed Bishop of Barcelona. ${ }^{167}$ While there is no information to confirm his presence in Hungary, two other manuscripts illuminated in Buda can be attributed to him: the Munich Aristeas and the Plato Corvina in El Escorial. ${ }^{168}$ This suggests that he might have made a journey to Hungary. ${ }^{169}$ The frontispiece of the Psalter is attributed by Annarosa Garzelli to Francesco de Rosselli and to the so-called Master of the Medici Iliad. There is documentation to prove that the former illuminator worked in Hungary, and his time in the country (1478/79-1481) even matches the presumed date when the manuscript was decorated (1476-1481). In her paper of 2010, Edina Zsupán localised the place where the copying was carried out and the frontispiece was made to Florence, based on the collaboration of the Master of the Medici Iliad, although in the catalogue entry of 2013, she no longer rules out the possibility that the entire Psalter may have been produced in Buda. ${ }^{170}$ The binding of the manuscript was almost certainly made in Buda, as evidenced by the Buda type of fore-edge, and this is not contradicted by Anthony Hobson's attribution of the binding to Felice Feliciano, for the humanist polymath may have been a member of the delegation that accompanied John of Aragon on his visit to Buda in 1479. ${ }^{171}$ With regard to where the internal figural initials were made, the smaller initials and the larger, penwork letters at the start of the sentences may be of decisive importance, for they are closely related to the 
initials in the Kálmáncsehi Breviary, as pointed out by Edina Zsupán, who thereby proved, with a high degree of probability, that the smaller initials were written into the manuscript in Buda. ${ }^{172}$ As these smaller initial letters were partially covered in several places by the figural, Northern Italianstyle initials, ${ }^{173}$ the latter must have been made at a later stage, and therefore also in Buda. (Fig. 36) The Northern Italian illuminator of the Psalter and the Gradual therefore worked (also) in Buda, and it can be reasonably posited that the scene of The Israelites Entering the Promised Land was painted into the choir book in Buda (although it cannot be entirely ruled out that the copying was carried out in Northern Italy, and that the partly illuminated manuscript was brought to Buda from there by the Italian illuminator.)

As already pointed out by Árpád Mikó, the attribution may also bring the date of the miniature in the Gradual closer to the date of the Psalter, probably around 1480 or slightly later, which is confirmed by the only date that can be associated with the Gradual, 1483, when the incunabulum of Klosterneuburg was published. ${ }^{174}$ The date does not conflict with those of the Flemish works either. Still, the most certain range of dates is provided by the marriage of Matthias and Beatrice in 1476, which is designated as the terminus post quem by the twin coat of arms, and the dating of the Vatican Missal to 1488-1490, whose Calvary miniature (fol. 103v) directly copied the background of the Resurrection in the Gradual. ${ }^{175}$

With all credit to Árpád Mikó, using the help of the Psalter, it is therefore possible to link the production of the miniature on fol. 7r of the Gradual firmly to Buda. Localising the origins of the illuminator within Northern Italian manuscript painting of the period, however, will remain impossible unless and until suitable stylistic parallels can be found. Scholars are in agreement about the origin from Lombardy, ${ }^{176}$ with some commentators narrowing this down to Milan, although this seems to be rather as a result of the city's central importance or the influence of Berkovits's hypothesis (that Giovanni Antonio Cattaneo da Mediolano came from Milan), rather than any specific analogues. ${ }^{177}$ Tünde Wehli puts forward Girolamo da Cremona as a possible stylistic parallel, referring to the shapes of the initials, the elegant poise of the hands and feet, and the capricious twists in the pleats. The similarities are not strong enough, however, to warrant the assumption of any stronger connection with Girolamo da Cremona, and there are also some substantial differences: whereas Girolamo's letter stems tend to recall architectural elements, in the Gradual they take the form of balusters; Girolamo's figures are sturdier and their faces are more rounded; and the folds of his draperies run more closely together, like fluting, than the looser, more random pleating in the scene of The Israelites Entering the Promised Land. Letter stems that are more closely reminiscent of those visible in the Gradual have been found in an antiphonary made by Pietro da Cemmo for the Augustinian monastery in Cremona, albeit in miniatures that were made some two decades later. ${ }^{178}$ Gyöngyi Török, in the catalogue for the King Matthias exhibition in 2008, deviates from the earlier assumption of Milanese training in favour of Bologna or Ferrara; in connection with the two Northern Italian illuminators who verifiably worked in Hungary. ${ }^{179}$ Péter Farbaky also points out certain signs that refer to them having been active in Ferrara (the influence of the Ferrara style in the case of Francesco da Castello, and documentary references to Giovanni Antonio Cattaneo), and raises the possibility that they may have arrived in Buda via Ferrara. ${ }^{180}$ On this basis, and taking into account the well-known mobility of Italian illuminators, it may be worthwhile pursuing investigations into the illuminator of the Northern Italian miniature in the Gradual not only within the narrower confines of Lombardy, but also among the manuscripts from further afield in Ferrara.

\section{WHERE THE GRADUAL WAS MADE: BUDA VERSUS VIENNA}

With regard to where the Gradual was made, it can be established that the choir book was copied by a scribe who had most probably studied in Northern Italy, and was illustrated by an illumi- nator from Northern Italy who certainly passed through Buda, and a Flemish illuminator who definitely spent time in Vienna. With these factors in place, a number of different scenarios can 
be drawn up for the creation of the manuscript, but first it is important to examine two further questions. Which of the illuminators - the Flemish or the Italian - worked first on the manuscript (or did they perhaps work simultaneously)? Secondly, did the Flemish master also work in Buda?

In assessing the possible answers to the first question, it is important to emphasise that nothing is known about the decoration in the lost first volume of the choir book. It is conceivable that it was partly, or even entirely, the work of the Italian master. Although it is far from conclusive, the fact that the scribe originated from Northern Italy may suggest that the decoration was initially entrusted to an illuminator from the same part of Europe. It is also possible that the copying was performed in Northern Italy, and that the illuminator then brought the manuscript from there to Buda, either partly or entirely unilluminated. The possibility that the Italian master came first is hinted at by the Italianate letter and ornamental frame of one of the initials made by the Flemish master, which imitates pearls and jewels (fol. 54r), ${ }^{181}$ and which may have been inspired by the Northern Italian-style miniature (or miniatures) in the Gradual, for a similar kind of brooch was also added to the initial of fol. $7 \mathrm{r}^{182}$ (Fig. 35) It is also true, however, that if the Flemish master did work in Buda, this motif would have been accessible to him in other Italian-style manuscripts as well. ${ }^{183}$ There is less likelihood of this if he worked on the Gradual in Vienna, however, without ever visiting Buda. If this is the case, then there is a higher probability that his miniatures were painted into the manuscript after those of the Italian master. ${ }^{184}$

After the miniature of Klosterneuburg was attributed to the Flemish illuminator, it was taken as granted by the literature that he passed through Buda, ${ }^{185}$ and attempts to demonstrate the master's knowledge of Buda have been made by Joachim Verspohl and his student, Zita Ágota Pataki, using certain iconographic details, although these seem to be not entirely convincing. ${ }^{186}$ At first sight, the fact that it was commissioned and owned by King Matthias would make Buda more likely than Vienna as the place where the Gradual was made, because the manuscripts that he did not commission from Italy were made in the capital of Hungary. It is true, of course, that a good decade earlier, in 1469, the missal that Matthias gave to a Franciscan monk named Tamás was decorated by the Lehrbüchermeister in Vienna, but in this case the illumination of the manuscript was arranged by the recipient of the gift, and not by the giver. ${ }^{187}$ Matthias, however, did have the opportunity to employ Viennese masters between 1485 and 1490, while the city was under his control, and the King did spend almost three quarters of his time here during that period. Although there is no direct evidence of Viennese craftsmen and traders sharing in the royal commissions, in addition to which it is known that Matthias's court in Vienna was supplied in the main from Italy and Hungary, ${ }^{188}$ Vienna may have played a role of some kind in the expansion of the Corvinian Library: in a letter dated 16 September 1489, Bartolomeo Fonzio asked János Móré, the Master of the Royal Treasury to send him a list of the books copied in Vienna. ${ }^{189}$

There are no further traces of the illuminator's activity in Buda or in Vienna. The influence of the Gradual can of course be seen in the Vatican Missal made for Matthias in Buda in 1488-90 (BAV Urb lat. 110): the city view in the background of the scene of the Crucifixion, with its onion domes, is an echo of the frontispiece of the choir book. ${ }^{190}$ For this, however, it is enough for the manuscript to have been present in Buda, even without the illuminator. There is also, at present, almost no companion to the frontispiece of the incunabulum of Klosterneuburg to be found in Viennese miniature painting in the second half of the fifteenth century. There is no evidence that the style of the Master of the Gradual influenced any of the illuminators operating in Vienna at the time (Ulrich Schreier and his workshop, the Master of the Breviary of Frederick III, the master of the Morandus Offizium, or, from the 1490s, the Master of the Wolfgang Missal). ${ }^{191}$ On the basis of our present knowledge, it is therefore not possible to decide with any certainty whether the Flemish illuminator, who demonstrably was present in Vienna, actually painted the Gradual in Vienna or in Buda. Following the investigation of the relationship between the Flemish and the Italian miniatures, however, it is possible to assert that, if the Flemish illuminator worked on the manuscript first, it is more likely that he did so in Buda, partly because the sources of the Italianate ornamentation on fol. $54 \mathrm{r}$ would have been more readily accessible in Buda, and partly 
because the Northern Italian illuminator who completed the decoration also lived in Buda. If, on the other hand, the Flemish illuminator never visited Buda, and illuminated the manuscript in Vienna, then this would imply that the commis- sion was given initially to the Northern Italian illuminator, and that the work was passed on to the Flemish master in Vienna at a later stage. For the moment, however, all these scenarios are purely hypothetical.

\section{CONCLUSION}

There are numerous open questions about the Gradual that are still waiting to be answered by further research. A more precise determination of where it was made, and a resolution of the dilemma of Vienna or Buda, may be approached more closely through a deeper understanding of the relationship between Vienna, King Matthias and the Corvinian Library. Also awaiting answers are the matters of the place occupied by the illuminator of the Italian miniature in Northern Italian manuscript painting and the codicological peculiarities of quire 22 , while new attributions may cast further light on the inner relationships of the whole group of Flemish manuscripts. With regard to the latter, attention should be paid to a manuscript produced around 1495 which was given to Philip the Fair (1478-1506), whose miniatures, at least on the basis of the available reproductions, seem to be stylistically close to those in the Gradual. ${ }^{192}$

At the same time, a few significant questions have been resolved through consideration and analysis of attributions put forward in the foreign literature, and through an examination of the script, which was long neglected in the discourse on the place of creation. The relationship of style that could be demonstrated between the Master of the Turin Augustine and the works grouped around him has not only made it impossible to question that the illuminator of the Gradual studied in the Netherlands, but has also facilitated the localisation of his origins to the area around Tournai. At the same time, the creation of the Gradual of King Matthias is linked to the cities of Buda or perhaps Vienna not only by the Klosterneuburg miniature of Saint Leopold, but also by the script that is tentatively attributable to a Northern Italian scribe. The Northern Italian origin of the scribe also raised the realistic possibility that the Italian illuminator was the first to work on the decoration of the Gradual, and did not take part in the decoration later, supplement- ing the part of the manuscript that had been left unfinished by the Flemish master.

These findings change the nature and direction of certain iconographical dilemmas, which played an important role in earlier research in determining the place where the Gradual was made. Instead of the work being produced or commissioned in France, another explanation must be sought for the presence of the fleur-de-lis on the king's gown in fol. 10r and the drapery in fol. 37r. (Figs. 2-3) Is it possible that the symbol was merely used as a general mark of royal rank, ${ }^{193}$ or did it have something to do with the fact that the illuminator came from Tournai, which belonged directly to the French crown, and therefore he immediately associated the social rank of a king with this particular ruler? ${ }^{194}$ Although this is still an open question, attempts to resolve this and other iconographical questions should now be approached from the now-certain context that the Gradual was made in Central Europe. A topic of iconography that this paper has not touched upon at all is also ripe for reconsideration, ever since the pioneering and still centrally important research of Erzsébet Soltész. In the light of the fleur-de-lis motif and its associations with the King of France, it is particularly apparent that the pictures made by the Flemish illuminator are, apart from the coat of arms, almost completely devoid of any details that would refer directly to King Matthias. Contrasting examples may be provided, on the one hand, by the Northern Italian miniature in which a figure on the letter stem, identified as the infant Hercules wrestling with serpents, has since the very beginning been associated by the literature with King Matthias, and on the other hand, by the other liturgical manuscripts of King Matthias, in which the system of coats of arms, portraits and emblems serve as representations of his royal power. ${ }^{195}$ Additionally, the question of an "iconographic programme" also requires further research. To 
what extent do these miniatures - which have an iconography that is undoubtedly unique among the known illustrations of graduals - constitute a well-considered, coherent programme, or set of sub-programmes, as suggested by Erzsébet Soltész, and to what extent are the connections merely ad hoc, with the depictions no more than literal interpretations of the texts? ${ }^{196}$ Whatever the answers to these questions may be (or however the intellectual achievement represented by the cycle is determined), the extraordinary ico- nography undeniably implies a certain degree of invention, and this raises the question of who this invention can be attributed to. When it comes to searching for possible iconographic precedents, and to evaluating the autonomous intellectual achievement expected of the illuminator, a good starting point may be provided by the group of Flemish works that formed the subject of the preceding discussion, and which, it is hoped, will be augmented with additional members as further research is carried out. ${ }^{197}$

\section{CODICOLOGICAL DESCRIPTION}

Graduale romanum, Proprium de tempore (From Holy Saturday until the $24^{\text {th }}$ Sunday after Pentecost)

Budapest, Országos Széchényi Könyvtár (National Széchénvi Library), Cod. lat. 424

Parchment, II, 201, I fols., $498 \times 370$ mm, Buda?, 1476-1490

Layout: The manuscript consists of 25 quires, each of which is 8 folios, with a separate bound bifolio at the end of the manuscript. After fol. 74, one page has been cut out, and the present numbering does not take this page into account. ${ }^{198}$ According to the rubric at the bottom of fol. $74 \mathrm{v}$ (feria. iij), the missing page began with the songs of the liturgy for the Wednesday after Pentecost, with a miniature at the top of the recto. A start was also made on cutting out the following miniature (fol. 76v). The mutilation certainly took place before 1721, because the catalogue compiled in that year for the Hofbibliothek in Vienna by Giovanni Benedetto Gentilotti (1672-1725) already counts 201 folios. ${ }^{199}$

Ruling: The margins are each ruled with two vertical red lines, and the place for the text is ruled using brown ink. The text blocks measure $385 \times 237 \mathrm{~mm}$. The borders of the miniatures are ruled with thin, very pale brown lines, to which the red music staves are aligned. The staves and notes were added after the lyric for the songs had been inscribed, for the red lines and the neumes sometimes cover the lettering. The borders surrounding the spaces set aside for the liturgical instructions are also ruled with thin, pale brown lines, which must have been drawn at the same time as the borders of the miniatures, for all of them are aligned with the brown line of the row of script (see fol. 76v). The bolder horizontal lines for the liturgical instructions were ruled after the musical notes had been written in (see fol. $75 \mathrm{v}$, where the notes exceed the stave, resulting in the text of the instructions having to be shifted further to the right of the space originally allocated to it).

Script: Gothic Textura Rotunda in five rows per page, square notation on a four-line system. The main text was written in black ink, while the liturgical instructions were written in black or red ink. The feast days are named in rubrics, and the beginnings of each song are marked with an abbreviation of the type of song, written in red ink. The rubrics naming the feast days, together with the instructions, are absent between fol. 95r and fol. 175v (except for fol. 98v and fol. 118v), with the text to be written in marked in cursive from fol. 119r onwards. Between fol. 139r and fol. $175 \mathrm{v}$, the rubrics indicating the song type are also absent, although this information is often included in smaller lettering. The notation is absent from the first row of fol. 171v, while on the rest of the page, as well as fol. 172 and fol. $175 \mathrm{v}$, the neumes have been written in a different, coarser hand. Starting with the 4 th row of fol. $169 \mathrm{r}$ and continuing until the middle of the 2nd row of fol. $175 \mathrm{v}$, unlike the other parts of the manuscript, the signs marked to indicate the place for the neumes, which were usually subsequently scratched away, can still be made out. ${ }^{200}$ 
Illumination: On fol. 3r, the miniature is three rows in height, with border decoration that fills all four margins. Originally, a historiated initial was probably intended to go here, because the first letter of the word Resurrexi has visibly had to be squeezed in between the miniature and the letter $e$. The further 46 miniatures are historiated initials, two rows in height (measuring on average $155 \times 165 \mathrm{~mm}$ ), at the start of each feast day. The letters following these are calligraphically formed, and between fol. $7 \mathrm{r}$ and fol. $17 \mathrm{v}$, and again between fol. 168r and fol. 197r, they were also given penwork decoration. The start of each song is marked by a smaller initial (35 mm high); the first four (fol. 1r) have Northern Italian-style letter-bodies consisting of coloured floral motifs on a gold-leaf base, while the others are either burgundy on blue or blue on burgundy initials, with white or gold filigree decoration. A pendrawn, black ink cross can be seen beside several of the miniatures, sometimes scratched away: see fols. 132r, 136v, 142r, 145v, 149r, 157r, 161r, $165 \mathrm{v}, 168 \mathrm{r}, 180 \mathrm{r}, 193 \mathrm{v}$. The function of these crosses is still unclear.

Binding: Brown leather, from 1755 (according to the inscription), with a gold imprint on the front middle of the Imperial Austrian coat of arms with the two-headed eagle, and the inscription: ' $\mathrm{E}$. A. B. C. V. / 17 G. L. B. V. S. B. 55' (Ex Augusta Bibliotheca Caesarea Vindobonensis. Gerardus Liber Baro Van Svieten Bibliothecarius.) ${ }^{201}$ The gold inscription on a red base along the spine reads: 'MISSAE / PRO DIEBUS / DOMINICIS' // 'COD. MS. / THEOLOG. / N. XVIII. / OL. S. N.' The Austrian coat of arms appears again on the back. The edges on all three sides are gilded.

Provenance: Within the decorative frame of fol. 3r, an angel is holding the coat of arms of Matthias and the House of Aragon placed on two separate shields, so the manuscript was probably commissioned jointly by the roval couple, and may have been in use in the chapel of Buda Castle. ${ }^{202}$ The manuscript appears in the catalogue produced by Giovanni Benedetto Gentilotti in 1721 (ÖNB Cod. Ser. n. 2207, fols. 10v-11r), by which time it was in the Hofbibliothek in Vienna. After the dissolution of the Austro-Hungarian Monarchy, and in accordance with the terms of a bilateral agreement on the distribution of cultural assets between Austria and Hungary, which was signed in Venice in 1932, the manuscript was transferred in 1933 to the library of the Hungarian National Museum, the legal predecessor to today's National Széchényi Library. The stamps and marks of these libraries can be found on the flyleaves of the manuscript. ÖNB mark: Cod. 1769, with, in red, an earlier assignation: VI. A. $18 .^{203}$

On its way between Buda and Vienna, the manuscript may have made a detour to Württemberg. ${ }^{204}$ In the study he wrote on the fate of the libraries of Württemberg, Klaus Schreiner cites a list of the books transferred to Vienna from the library of the Duke of Württemberg after the Battle of Nördlingen in 1634, which mentions a very elegant "Missale secundum usum Ecclesiae Catholicae in chorali," decorated with fine miniatures, that originated from the library of King Matthias. ${ }^{205}$ Schreiner managed to identify this with an item in the Gesamtkatalog of 1652 of Ferdinand III, King of Hungary (1608-1657) and Holy Roman Emperor, where the manuscript is listed as "Rituale et Graduale Musicum Romanum," although there is no reference to its provenance. ${ }^{206}$ Csaba Csapodi used these listings to identify the manuscript as the Gradual of King Matthias. ${ }^{207}$ This may seem plausible, because there is no other choir book among the Corvinian manuscripts which are still kept in Vienna today. or which were transferred to Budapest; nor is there any other liturgical manuscript, which implies that, notwithstanding the fact that the unusual expression "missale in chorali" may initially give cause for doubt, the descriptions only match the Gradual of King Matthias. Any signs of its earlier history, if there were any, were probably removed when the volume was rebound in $1755 .^{208}$ Concerning how the manuscript ended up in Württemberg, Schreiner describes a potential scenario, in which two theologians from Tübingen. Stephan Gerlach (1546-1612) and Salomon Schweigger (1551-1622), were on legation to Constantinople in 1573-1575, suggesting that the choir book was taken to the Ottoman capital, together with other Corvinian manuscripts, after the occupation of Buda. ${ }^{209}$ In the absence of corroborating source data, however, this suggestion remains merely hypothetical. It is worth noting that one of the Ficino Corvinian manuscripts in Wolfenbüttel (HAB Cod. 12 Aug. $4^{\circ}$ ) was given to Augustus II, Duke of Braunschweig-Wolfenbüttel 
(1579-1666) by Thomas Lansius (1577-1657), a professor at Tübingen University.

There is no way of knowing how the manuscript was taken from Buda. The Gradual cannot be definitively identified with the object described in the inventory of goods taken by Queen Mary from the royal chapel in Buda to Bratislava (Pozsony) in 1530, even taking into account the text cited by Csapodi, which refers to "Quatuor libri in pergameno in latis voluminibus cantules pro choro," which Emperor Maximilian II ordered to be brought to Vienna in $1569 .^{210}$ The question is how to reconcile the journey made from Buda to Vienna via Bratislava with the transportation of the manuscript from Württemberg to Vienna, even though the latter took place decades later.

Literature: DENIS 1795, no. 827; Catalogue Tabulae 1864, 288: CsONTOSI 1881, 154: VARJú 1908, 5-20; Hevesy 1923, 32-33, 78; HofFMANN 1929, 86; Hermann 1933, 117-120; Hoffmann
1933, 296-297; RADó 1941, 14; BERKOVITS 1945; Kardos 1955, 406-407; BERKOVITS 1959; Berkovits 1962, 62-73; SzIGETI 1963; CsAPODI 1964, 207-208; Porcher 1964, 124; Soltész 1968; RAdOCSAY-SOLTÉSz 1969, 25-27, 65-67. pls. XXXVI-XXXVIII; SzIgeti 1969; Csapodi 1973, 420-421; BALOGH 1975, 235-236; SoLtész 1980; Csapodi 1981; Csapodi - CsapodinÉ GÁRDONYI 1976, 22, 44; SZENDREI 1981, 43, 63; Catalogue Budapest 1985, 136 (Soltész Zoltánné): SIEvEKING 1986, 142: TÖRÖK 1992, 366367; CseJdy 1994; Hindman 1997, 81; Komada 2000, 128-129, 132; VERSPOHL 2000, 157-160, 166, 170-177; Catalogue Budapest 2002, 232 (FöLdEsI, Ferenc); Catalogue Modena 2002, 281-283 (Földesi, Ferenc); Di PIETro LomBARDI 2002, 119; WEHLI 2002, 246; MARUBBI 2003, 96; Wehli 2003, 84; Pataki 2005, Vol. 1. 213-215, 224, Vol. 2. 401; Soltész 2007; TöröK 2008; MADAS 2009, 46, 66: MIKÓ 2009. 51; Мikó 2010, 265-266; WiJSMAN 2010, 469; ZSUPÁN 2014 a.

\section{ABBREVIATIONS}

Institutions, libraries, archives

$\begin{array}{ll}\text { AST } & \text { Turin, Archivio di Stato Torino } \\ \text { BAV } & \text { Rome, Biblioteca Apostolica Vaticana } \\ \text { Beinecke } & \text { New Haven, Beinecke Rare Book and Manuscript Library } \\ \text { BEU } & \text { Modena, Biblioteca Estense Universitaria } \\ \text { BL } & \text { London, British Library } \\ \text { BnF } & \text { Paris, Bibliothèque nationale de France } \\ \text { BNU } & \text { Turin, Biblioteca Nazionale Universitaria di Torino } \\ \text { Bodl. } & \text { Oxford, Bodleian Library } \\ \text { BSB } & \text { Munich, Bayerische Staatsbibliothek } \\ \text { FLP } & \text { Philadelphia, Free Library of Philadelphia } \\ \text { Getty } & \text { Los Angeles, J. Paul Getty Museum } \\ \text { HAB } & \text { Wolfenbüttel, Herzog August Bibliothek } \\ \text { Hunt. } & \text { San Marino CAA), Huntington Library } \\ \text { KB } & \text { The Hague, Koninklijke Bibliotheek } \\ \text { KBR } & \text { Brussels, Koninklijke Bibliotheek van België / Bibliothèque Royale de Belgique } \\ \text { Marmottan } & \text { Paris, Musée Marmottan, Wildenstein Collection } \\ \text { Mazarine } & \text { Paris, Bibliothèque Mazarine } \\ \text { Met. } & \text { New York, Metropolitan Museum of Art } \\ \text { OSZK } & \text { Budapest, Országos Széchényi Könyvtár (National Széchényi Library) } \\ \text { ÖNB } & \text { Vienna, Österreichische Nationalbibliothek } \\ \text { ÖS OGV } & \text { Vienna, Österreichisches Staatsarchiv, Orden vom Goldenen Vlies } \\ \text { PML } & \text { New York, Pierpont Morgan Library }\end{array}$

\section{BIBLIOGRAPHY}

Alexander 1992 - Alexander, Jonathan J. G.: Medieval Illu minators and Their Methods of Work, New Haven - London. 1992.

AleXANDER 2001 - Alexander, Jonathan J. G.: Francesco da Castello in Lombardy and Hungary, in Italy \& Hungary, Humanism and Art in the Early Renaissance. Acts of an
International Conference, Florence, Villa I Tatti, June 6-8, 2007. Eds. Farbaky, Péter - Waldman, Louis A. Cambridge (Mass.), 2011. 267-291.

BALogh 1927 - BALogH, Jolán: A madocsai apát, „a királyi könvvek miniátora" [The Abbot of Madocsa. "Illuminator of the Royal Books"], Henszlmann-Lapok 1. 1927. Nr 5, 1-6. 
Balogh 1975 - Balogh, Jolán: Die Anfänge der Renaissance in Ungarn: Matthias Corvinus und die Kunst, Graz, 1975. BERKOVITS 1941 - BERKOVITS, Ilona: La miniatura nella corte di Mattia Corvino: Ferrara ed il Rinascimento ungherese, Budapest, 1941.

Berkovits 1945 - Berkovits, Ilona: Egy corvin-kódex származása [The Provenance of a Corvinian Manuscript], Magyar Könyvszemle 35. 1945. 22-37.

BERKOVITS 1959 - BerkovITs, Ilona: Egy korvina miniatura [A Miniature from a Corvinian Manuscript], Müvészettörténeti Értesítő 8. 1959. 250-259.

Berkovits 1962 - Berkovits, Ilona: A magyarorszáoi Corvinák [Corvinian Manuscripts from Hungary], Budapest, 1962 .

Berkovits 1963 - Berkovits, Ilona: Corvinen: Bilderhandschriften aus de Bibliothek des Königs Matthias Corvinus, Berlin, 1963

Bischoff 1990 - BIschoff, Bernhard: Latin Paleography: Antiquity and the Middle Ages, Cambridge, 1990.

Brinkmann 1997 - Brinkmann, Bodo: Die Flämische Buchmalerei am Ende des Burgunderreichs: Der Meister des Dresdener Gebetbuchs und die Miniaturisten seiner Zeit, Turnhout, 1997.

Broekhujusen 2009 - Broekhujusen, Klara H.: The Masters of the Dark Eyes: Late Medieval Manuscript Painting in Holland, Turnhout, 2009

Cardon 1996 - CARDON, Bert: Manuscripts of the Speculum Humanae Salvationis in the Southern Netherlands (c. 1410 - c. 1470). A contribution to the study of the 15th century book illumination and of the function and meaning of historical symbolism, Leuven, 1996.

Catalogue Bologna 2012 - I corali benedittini di San Sisto a Piacenza, exhibition catalogue, Museo Civico Medievale, Bologna. Ed. BoLlati, Milvia. Bologna, 2012

Catalooue Brussels 1996 - L'ordre de la Toison d'or de Philippe de Bon à Philippe le Beau, 1430-1505: idéal ou reflet d'une société? Exhibition catalogue, Bibliothèque Royale de Belgique, Brussels. Ed. Cockshaw, Pierre. Bruxelles, 1996.

Catalogue Brussels - Florence - Saint Petersburg 1996 Flemish Illuminated Manuscripts, exhibition catalogue, Bibliothèque Royale de Belgique, Brussels - Museo Bardini, Florence - The State Hermitage Museum, Saint Petersburg. Eds. SMEYERs, Maurits - VAN DER STock, Jan. Ghent - New York. 1996

Catalogue Brussels-Paris 2011 - Miniatures flamandes 1404 1482, exhibition catalogue, Bibliothèque Royale de Belgique. Brussels - Bibliothèque nationale de France. Paris. Eds. Bousmanne, Bernard - Delcourt, Thierry. Bruxelles-Paris, 2011.

Catalogue Budapest 1985: Kódexek a középkori Magyarországon [Manuscripts in Medieval Hungary], exhibition catalogue, Országos Széchényi Könyvtár, Budapest. Ed. VIZKELETY, András. Budapest. 1985.

Catalogue Budapest 2002 - Uralkodók és Corvinák. Az Országos Széchényi Könyvtár jubileumi kiállitása alapításának 200. évfordulóján. 2002. május 16. - augusztus 20. / Potentates and Corvinas. Anniversary exhibition of the National Széchényi Library, 16 May - 20 August 2002, exhibition catalogue, Országos Széchénvi Könvvtár, Budapest. Ed. KARSAY, Orsolya. Budapest, 2002.

Catalogue Budapest 2008 - Matthias Corvinus, the King: Tradition and Renewal in the Hungarian Royal Court, 1458-1490, exhibition catalogue, Budapesti Történeti Múzeum, Budapest. Eds. FARBAKY, Péter et al. Budapest, 2008

Catalogue Freiherr von Lanna 1911 - Sammlung Freiherr von Lanna, Prag. Manuskripte und Bücher XXXIII. Auktion Gilhofer und Ranschburg), Wien, 1911.

Catalogue Klosterneuburg 1985 - Der Heilige Leopold: Landesfürst und Staatssymbol, exhibition catalogue. Stiftsmuseum, Klosterneburg. Ed. RöHRIG, Floridus. Wien. 1985
Catalogue London - Los Angeles 2003 - Illuminating the Renaissance: The Triumph of Flemish Manuscript Painting in Europe, exhibition catalogue, Roval Academy of Arts. London - The J. Paul Getty Museum, Los Angeles. Eds. Kren, Thomas - McKendrick, Scot. Los Angeles, 2003

Catalogue Modena 2002 - Nel segno del corvo: libri e miniature della biblioteca di Mattia Corvino re d'Ungheria (1443-1490), exhibition catalogue, Biblioteca Estense Universitaria, Modena. Ed. MiLano, Ernesto. Modena. 2002.

Catalogue of the Stowe Manuscripts 1895-1896 - Catalogue of the Stowe Manuscripts in the British Museum, London. 1895-1896.

Catalogue Tabulae 1864 - Tabulae codicum manu sciptum praeter graecos et orientales in Bibliotheca Palatina Vindobonensis Asservatorum. Vol. 1. Vindobona. 1864.

CLARK 2000 - Clark, Gregory T.: Made in Flanders: The Master of the Ghent Privileges and Manuscript Painting in the Southern Netherlands in the Time of Philip the Good, Turnhout, 2000

CLARK 2006 - CLARK, Gregory T.: Made in Flanders and the Master of the Ghent Privileges: a Second Coda, in Tributes in Honor of James Marrow. Studies in Painting and Manuscript Illumination of the Late Middle Ages and Northern Renaissance, eds. HaMBURGER, Jeffrey F. - KORTEWEG, Anne S. London, 2006. 155-161.

CSAPODI 1964 - CsAPODI, Csaba: Beatrix királyné könyvtára Résumé: La bibliothèque de la Reine Béatrice, Magyar Könyvszemle 80. 1964. 201-224.

CsaPODI 1973 - CsAPODI, Csaba: The Corvinian Library: History and Stock, Budapest, 1973

CsapoDI 1981 - Csapodi, Csaba: Soltész Zoltánné: A Mátyás Graduale [Review on Soltész Zoltánné: The Gradual of King Matthias], Magyar Könyvszemle 97. 1981. 253255.

Csapodi - Csapodiné Gárdony 1976 - Csapodi, Csaba - CsaPODINÉ GÁRDONYI, Klára: Bibliotheca Corviniana, Budapest. $1976^{2}$

CseJdY 1994 - CseJdDY. Júlia: Mátyás Graduálé: A németalföldi miniatúra ciklussal kapcsolatos megoldatlan kérdések The Gradual of King Matthias: Unresolved Ouestions Related to the Cycle of Flemish Miniatures], unpublished PhD thesis, Eötvös Loránd University, Budapest, 1994.

Csontosi 1881 - Csontosi, János: Latin corvin-codexek bibliographiai jegyzéke [Bibliographical Inventory of Latin Corvinian Manuscripts], Magyar Könyvszemle 6. 1881. 137-176.

De la Mare 1985 - De la Mare, Albinia: New Research on Humanistic Scribes in Florence, in Miniatura fiorentina del Rinascimento, 1440-1525, ed. Garzelli, Annarosa. Firenze, 1985. Vol. 1, 393-591.

DeNIS 1795 - DeNIs, Michael: Codices manuscripti theologici latini bibliothecae Palatinae Vindobonensis, Vol. 1, Pars. 3. Vindobona, 1795

Derolez 2003 - Derolez, Albert: The Paleography of Gothic Manuscript Books from the Twelth to Early Sixteenth Century, Cambridge, 2003.

Di Piftro Lombardi 2002 - Di Pietro Lombard, Paola: Mattia Corvino e i suoi emblemi, in Catalogue Modena 2002, 117-128.

DOUTREPONT 1909 - DOUTREPONT Georges: La Littérature française à la cour des ducs de Bourgogne: Philippe le Hardi, Jean sans Peur, Philippe le Bon, Charles le Téméraire, Paris, 1909.

DOYLE-LOWDEN-MCKeNDRICK 2011 - DOYLE. Kathleen LowDEn, John - McKENDRICK, Scot: Royal Manuscripts: The Genius of Illumination, exhibition catalogue, British Library, London. London, 2011.

FARBAKY 2013 - FARBAKY, Péter: A párizsi Cassianus-corvina és a Corvina-könyvtár lombard-ferrarai kapcsolatai TThe Lombard and Ferrarese Relations of the Cassian Manuscript from Paris and the Corvinian Library], Ars Hungarica 39. 2013. 44-53. 
FontIUs 1931 - FonTIUs, Bartholomaeus: Epistolarum III, ed. JuHász, László.

GAY 2006 - GAY, Richard: Scribe Biographies, in Flemish Manuscript Painting in Context: Recent Research, ed. GreenBerG, Mark. Los Angeles, 2006. 183-188.

GeIRNAERT 1992 - GeIRNAERT. Noel: Classical Texts in Bruges around 1473: Cooperation of Italian Scribes, Bruges Parchment-Rulers, Illuminators and Book-Binders for Johannes Crabbe in Fifteenth-Century Flemish Manuscripts in Cambridge Collections = Transactions of the Cambridge Bibliographical Society 10. 1992. 173-181.

GIL 1999 - GIL. Marc: Du Maître du Mansel au Maître de Rambures. Le milieu des peintres et des enlumineurs de Picardie, ca 1440-1480, PhD thesis, Université ParisSorbonne - Paris IV. Paris, 1999.

GIL 2008 - GIL. Marc: Jean du Chesne, écrivain lillois à la fin de l'époque bourgignonne, in Manuscript Studies in the Low Countries, ed. As-VIJvers. Anne Margreet W. Groningen. 2008. 159-184.

Gil 2014 - GIL, Marc: La théorie de l'atelier et de l'officine dans la miniature septentrionale (L. Delaissé): Modèles alternatifs à la lumière des sources et de la recherche actuelle, in Image et images du Moyen Âge. Mélanges en l'honneur de Jacques Charles Lemaire, ed. GoLDSCHLÄGER, Alain. Orléans, 2014. 109-127.

GuMBERT 2008 - GuMBERT, Johan P.: Can a Fleming Write Italian? in Manuscript Studies in the Low Countries, ed. AsVIJvers, Anne Margreet W. Groningen. 2008. 207-215.

HAIDINGER 1998 - HAIDINGER. Alois: Verborgene Schönheit: Die Buchkunst im Stift Klosterneuburg, exhibition catalogue, Stiftsmuseum, Klosterneuburg. Wien, 1998.

Hans-Collas-Schandel 2009 - Hans-Collas, Ilona - ScHaNDEL, Pascal: Manuscrits enluminés des anciens Pays-Bas méridionaux. 1. Manuscrits de Louis de Bruges (Catalogue of the Bibliothèque nationale de France), Paris, 2009 .

Hermann 1932 - Hermann, Hermann Julius: Die Handschriften und Inkunabeln der Italianischen Renaissance, 3. Mittelitalien: Toskana, Umbrien, Rom, Leipzig, 1932.

Hermann 1933 - Hermann, Hermann Julius: Die Handschriften und Inkunabeln der italianischen Renaissance: 4. Unteritalien: Neapel, Abruzzen, Apulien und Calabrien, Leipzig, 1933.

Hevesy 1923 - Hevesy, André de: La bibliothèque du roi Matthias Corvin, Paris, 1923.

Hindman 1997 - Hindman, Sandra: Christ Entry into Jerusalem. Leaf from an Evangelary, in Hindman. Sandra et al.: The Robert Lehman Collection: IV. Illuminations, New York. 1997. 77-83.

Hoffmann 1929 - Hoffmann, Edith: Régi magyar bibliofilek [Old Hungarian Bibliophiles]. Budapest. 1929.

Hoffmann 1933 - Hoffmann, Edith: A Bécsből hazakerült műkincsek kiállítása a Nemzeti Múzeumban. III A kéziratok [Exhibition of Artworks Returned from $\mathrm{V}_{\mathbf{i}}$ enna, at the Hungarian National Museum. III. Manuscripts], Magyar Müvészet 5. 1933. 289-303.

Kardos 1955 - Kardos, Tibor: A magyar humanizmus kora [The Age of Humanism in Hungary], Budapest 1955.

KeMPERDicK 1993 - KeMPERDICK, Stephan: Zur LochnerRezeption ausserhalb Kölns, in Stefan Lochner, Meister $z u$ Köln, exhibition catalogue. Wallraf-Richartz Museum, Köln. Ed. ZEHNDER, Frank Günter. Köln, 1993 69-80.

KNAUZ 1862 - KNAUZ, Nándor: A budai királyi várpalota kápolnája, Pest, 1862.

Komada 2000 - Komada, Akiko: Les illustrations de la Bible historiale - Les manuscrits réalisés dans le Nord, $\mathrm{PhD}$ thesis, Université Paris-Sorbonne - Paris IV. Paris, 2000.

LABORDE 1909 - LABORDE, Alexandre: Les manuscrits à peintures de la Cité de Dieu de Saint Augustin. Paris, 1909.

Librairie des ducs de Bourgogne 2000 - La Librairie des ducs de Bourgogne. Manuscrits conservés à la Bibliothèque royale de Belgique. Vol. I. Textes liturgiques, ascétiques, théologiques, philosophiques et moraux, eds. BousMANNE, Bernard - VAN HooereBeck. Céline. TurnhoutBruxelles, 2000.

Lieftinck 1954 - Lieftinck, Gerard Isaac: Pour une nomenclature de l'écriture livresque de la période dite gothique, in BISCHOFF, Bernard - LIEFTINCK. Gerard Isaac - BATteldi, Guilio: Nomenclature des écritures livresques du IXe au XVIe siècle, Paris, 1954. 15-34.

LONCHI 1998 - LONCHI, Lisa: Tra Busseto, Cremona e Milano: gli „scriptoria” per il Pallavicino, in L'oro e la porpora, le arte a Lodi nel tempo del vescovo Pallavicino (14561497), exhibition catalogue, Chiesa di San Cristoforo. Lodi. Ed. Marubbi, Mario. Cinisello Balsamo (Milano), 1998. 141-146.

LudiKová 2005 - Ludiková, Zuzana: The Fate of Buda's Ecclesiastical Treasures, in Mary of Hungary: the Oueen and Her Court, 1521-1531, exhibition catalogue, Budapest History Museum. Budapest - Slovenská národná galéria. Bratislava. Eds. RétheLYI, Orsolva et al. Budapest, 2005. 129-136

Madas 2009 - Madas, Edit: La Bibliotheca Corviniana et les corvina authentiques", in Matthias Corvin, les bibliothèques princières et la genèse de l'état moderne, eds. MaILLARD, Jean-François - MonoK, István - NebBIAI, Donatella. Budapest, 2009. 35-78.

Marrow 2001 - MARRow. James H.: Miniatures from a Gospel Lectionary (Evangelary), in Leaves of Gold. Manuscript Illumination from Philadelphia, exhibition catalogue. Philadelphia Museum of Art. Philadelphia - Frist Center for the Visual Arts, Nashville. Ed. TANIs, James R. Philadelphia, 2001. 137-140.

Marubbi 1992 - Marubbi, Mario: Giovan Pietro da Cemmo miniatore, Arte Lombarda 101. 1992. 7-31.

Marubbi 1998 - Marubbi, Mario: Carlo Pallavicino, vescovo umanista e mecenate, in L'oro e la porpora, le arte a Lodi nel tempo del vescovo Pallavicino (1456-1497), exhibition catalogue, Chiesa di San Cristoforo, Lodi. Ed. MARUBBi, Mario. Cinisello Balsamo (Milano), 1998. 15-24.

Marubbi 2003 - Marubbi, Mario: Miniatura tra Lombardia e Ungheria: Riflessioni su Bartolomeo Gossi, Francesco da Castello e Giovanni Antonio Cattaneo, Arte Lombarda 139. 2003. 86-99.

Mikó 2009 - Mikó, Árpád: A reneszánsz Magyarországon [The Renaissance in Hungary]. Budapest, 2009.

Mıкó 2010 - Mıкó, Árpád: Beatrix királyné psalteriumának helye: Kérdések a Bibliotheca Corvina könyvfestői és könyvkötői körül [The Place of Queen Beatrice's Psalter: Questions Surrounding the Illuminators and Bookbinders of the Bibliotheca Corviniana], Müvészettörténeti Értesítö 59. 2010. 261-273.

Novasconi 1976 - Novasconi, Armando: Le miniature di Lodi, Lodi 1976

O'Conor 1818-1819 - O'Conor, Charles: Bibliotheca Ms. Stowensis: A Descriptive Catalogue of the Manuscripts in the Stowe Library, 2 Vols. Buckingham. 1818-1819.

PÄCht-Jenni 1975 - PÄCHT, Otto - JenNI, Ulrike: Die illuminierten Handschriften und Inkunabeln der Österreichischen Nationalbibliothek. Holländische Schule, Wien. 1975

Pächt-Jenni-Thoss 1983 - PÄCht, Otto - Jenni, Ulrike Thoss, Dagmar: Die illuminierten Handschriften und Inkunabeln der Österreichischen Nationalbibliothek. Flämische Schule I, Wien, 1983.

Pächt-Thoss 1990 - PÄ́ht, Otto - Thoss, Dagmar: Die il luminierten Handschriften und Inkunabeln der Österreichischen Nationalbibliothek. Flämische Schule II, Wien. 1990

PATAKI 2005 - PATAKI, Zita Ágota: „nympha and amoenum fontem dormiens"(CIL VI/5, $3 *$ e). Ekphrasis oder Herrscherallegorese? Studien zu einen Nymphenbrunnen sowie zur Antikenrezeption und zur politischen Ikonographie am Hof des ungarischen Königs Matthias Corvinus, 2 Vols. Stuttgart, 2005. 
Perger 1982 - Perger, Richard: Matthias Corvinus und Wien, in Matthias Corvinus und die Renaissance in Ungarn, exhibition catalogue, Renaissanceschloss, Schallaburg. Eds. Stangler, Gottfried - Csáky, Moritz. Schallaburg, 1982. 241-249.

Pócs 2013 - Pócs, Dániel: Il mito di Ercole: arte fiorentina al servizio della rappresentazione del potere di Mattia Corvino, in Mattia Corvino e Firenze: Arte e Umanismo alla corte del re di Ungheria, exhibition catalogue, Museo di San Marco, Biblioteca di Michelozzo, Firenze. Eds. FARBAKY, Péter et al. Firenze-Milano, 2013. 222-229.

Porcher 1964 - Porcher, Jean: Review on Berkovits Ilona: Corvinen. Bilderhandschriften aus der Bibliothek des Königs Matthias Corvinus, Bulletin des Bibliothèques de la France 9. 1964. 124-125.

RADó 1941 - RADó, Polikárp: Index codicum manuscripti liturgicum Regni Hungariae, Budapest, 1941.

Radocsay-Soltész 1969 - Radocsay, Dénes - Soltész. Zoltánné: Francia és németalföldi miniatúrák Magyarországon [French and Flemish Miniatures in Hungary], Budapest, 1969.

RoLAND 2003 - RoLAND, Martin: Buchmalerei, in Geschichte der Bildenden Kunst in Österreich, Vol. 3: Spätmittelalter und Renaissance, ed. Rosenauer, Artur. München, 2003. 521-546.

SCHREINER 1974 - SCHREINER, Klaus: Württembergische Bibliotheksverluste im Dreißigjährigen Krieg, Archiv für Geschichte des Buchwesens 14. 1974. 655-1027.

SCHUlLER-Juckes 2009 - SCHUlleR-JuCKES, Michaela: Ulrich Schreier und seine Werkstatt. Buchmalerei und Einbandkunst in Salzburg, Wien und Bratislava im späten Mittel alter, PhD thesis, Universität Wien. Wien, 2009.

SHAILOR 1984 - ShaILOR, Barbara A.: Catalogue of Medieval and Renaissance Manuscripts in the Beinecke Rare Book and Manuscript Library, Vol. 1. New York. 1984.

SieveKING 1986 - SieveKING, Hinrich: Der Meister des Wolfgang-Missale von Rein: zur österreichischen Buchmalerei zwischen Spätootik und Renaissance, München, 1986.

SMEYERs 1999 - SMeYers, Maurits: Flemish Miniatures from the 8th to the mid-16th Century. The Medieval World on Parchment, Turnhout, 1999.

Soltész 1968 - Soltész, Elisabeth: Zur Herkunft des Corvin-Graudals und zur Ikonographie seiner Miniaturen Magyar Könyvszemle 84. 1968. 334-342.

Soltész 1982 - Soltész, Elisabeth: Das Corvinus Graduale Hanau-Budapest, 1982

Soltész 2007 - Soltész, Zoltánné: Mátyás-Graduale [The Gradual of King Matthias], preface: MoNOK. István, epilogue: FöLDEsI, Ferenc. Budapest, 2007.

SZENDREI 1981 - SZENDREI, Janka: A magyar középkor hangjeoyes forrásai [Notated Sources from Medieval Hungary], Budapest, 1981.

SZENDREI 1985 - SZENDREI, Janka: A középkori magyarországi zene története [The History of Music in Medieval Hungary], in Catalooue Budapest 1985, 67-76.

SzIGETI 1963 - SzIGETI, Kilián: A Mátyás-graduale eredetének kérdése $\lceil$ On the Origin of the Gradual of King Matthias]. Magyar Könyvszemle 79. 1963. 327-332.

SzIGETI 1969 - SzIGETI, Kilián: Mátyás király liturgikus kódexei [The Liturgical Manuscripts of King Matthias] Magyar Könyvszemle 85. 1969. 268-273.

TiETZE 1911 - TIETZE, Hans: Der Illuminierten Handschriften der Rossiana in Wien - Lainz, Leipzig,1911.

Tournoy 2006 - TourNoy, Gilbert: An Italian Scribe at Bruges in the Second Half of the Fifteenth Century: Francesco Florio, in Medieval Manuscripts in Transition: Tradition and Creative Recycling; eds. Classens, Geert H. M. - VERBEKE. Werner. Leuven, 2006. 261-308.
TöRöK 1992 - TöRöK, Gyöngyi: Missale des Matthias Corvi nus, in Biblioteca Apostolica Vaticana: Liturgie und Andacht im Mittelalter, exhibition catalogue, Erzbischöfliches Diözesanmuseum, Köln. Ed. PLOTZEK, Joachim M. Stuttgart, 1992. 366-367.

TöRöK 2008 - TöRöK. Gyöngyi: The "Matthias Gradual." in Catalogue Budapest 2008, 426-428.

Van Buren 1985 - VAn Buren. Anne: Review on Otto Pächt Ulrike Jenni: Dagmar Thoss: Die illuminierten Handschriften und Inkunabelen der Österreichischen Nationalbibliothek. Flämische Schule I, Ser. I, Vol. VI, Art Bulletin 67. 1985. 327-331.

VAN Buren 1999 - VAn Buren. Anne: Willem Vrelant. Questions and Issues, Revue belge d'archéologie et d'histoire art 68. 1999. 3-30.

VANWIJNSBERghe 2001 - VANWJJNSBERGHE, Dominique: "De fin or et d'azur", Les commenditaires de livres er le métier de l'enluminure à Tournai à la fỉn du Moyen Age (XIVeXVe siècles), Leuven, 2001.

VARJU 1908 - VARJU, Elemér: Két corvina-kézirat [Two Corvinian Manuscripts], Magyar Könyvszemle 19. 1908. 1-25.

VERSPOH 2000 - VERSPOH Franz-Joachim: KleinformGroßform: Italienisches Formgefühl und Ungarisches Anspruchsniveau: die Kunstentfaltung am Hof des Matthias Corvinus, in L'Europa e l'arte italiana: Per $i$ cento anni dalla fondazione del Kunsthistorishes Institut in Florenz. Convegno internazionale, Firenze, 22-27 settem bre 1997, ed. SEIDEL, Max. Venezia, 2000. 156-185.

WEHLI 2002 - WEHLI. Tünde: La pittura del libro alla corte di re Mattia a Buda, in Catalogue Modena 2002, 241-247.

WeHLI 2003 - WeHLI. Tünde: Influssi Lombardi nella miniatura della corte di Mattia Corvino. Arte Lombarda 139. 2003. 81-86.

WeHLI 2005 - WEHLI, Tünde: Mátyás király ferences missaléja [The Franciscan Missal of King Matthias], in A ferences lelkiség hatása az Újkori Közép-Európa történetére és kultúrájára [The Influence of Franciscan Spirituality on the History and Culture of Central Europe in the Modern Era], eds. Oze, Sándor - Medgyesy-SchmikLi, Norbert. Budapest, 2005. 865-874.

WiJsman 2010 - WiISMAN. Hanno: Luxury Bound. Illustrated Manuscript Production and Noble and Princely Bookownership in the Burgundian Netherlands (1400-1550), Turnhout, 2010

WINKLER 1925 - WINKLER. Friedrich: Die flämische Buchmalerei des XV. und XVI. Jahrhunderts, Leipzig, 1925.

ZANONI 1955 - ZANONI, Felice: I corali del duomo di Cremona e la miniatura cremonese del Ouattrocento, Annali della Biblioteca Governativa e Libreria Civica di Cremona 8. 1955. v-cviv.

ZSUPÁN 2010 - ZsuPÁN, Edina: A Beatrix-psalterium Geneziséhez [On the Genesis of the Beatrix-Psalter] Müvészettörténeti Értesítö 59. 2010. 233-260

ZsupÁN 2013 - Zsupán. Edina: Salterio di Beatrice d'Aragona, in Mattia Corvino e Firenze: Arte e Umanismo alla corte del re di Ungheria, exhibition catalogue, Museo di San Marco, Biblioteca di Michelozzo. Firenze. Eds. FARBAKY, Péter et al. Firenze-Milano, 2013. 170-171.

Zsupán 2014A - Zsupán, Edina: Matthias Corvinus Graduale, in Image and Christianity: Visual Media in the Middle Ages, exhibition catalogue. Pannonhalmi Főapátság. Pannonhalma. Ed. BoKODY, Péter. Pannonhalma, 2014. 282

ZsupáN 2014B - ZsupáN, Edina: Zur Genese der BeatrixPsalteriums, in Corvina Augusta: Die Handschriften des Königs Matthias Corvinus in der Herzog August Bibliothek Wolfenbüttel, ed. Zsupán, Edina. Budapest. 2014. 179-211. 


\section{NOTES}

1 This paper is an extended version of the magisterial thesis I defended in 2015 (Budapest, Eötvös Loránd University, Faculty of Humanities, Department of Art History). I am indebted to Gábor Endrődi for his enthusiastic work as my supervisor, for his practical ideas, his outstanding observations, his constructive criticism, and his constant encouragement. I am grateful to Dániel Pócs for his invaluable conversations, his comments, and the loan of his books. I would like to thank Ágnes Tóvizi for her productive consultation, and for her assistance in arranging for me to view the original Gradual. I thank Ferenc Földesi, head of the Department of Manuscripts at the National Széchényi Library, for allowing me to handle the original codex. Last but not least. I would like to express my gratitude to Mária Árvai for her meticulous, perceptive and critical reading of the paper in its various stages. I was able to examine the original manuscripts in Turin, London and Oxford (AST Jb. III. 12, BNU L I 6, BL Stowe 27, BL Royal 14 E IV, Bodl. Laud. Misc. 653) thanks to the Peregrination budget of the Research Centre for the Humanities, Hungarian Academy of Sciences (Budapest).

${ }^{2}$ For the digitalised manuscript, see Bibliotheca Corviniana Digitalis URL: <http://www.corvina.oszk.hu/corvinashtml/graduale.html $>$ [last retrieved: 21. 10. 2016].

3 SOLTÉsz 1982; Hungarian-language version: 1980.

${ }^{4}$ CSEJDY 1994.

5 All three possibilities are listed in: Catalogue Budapest 2002, 232 (FöLDESI, Ferenc).

${ }^{6}$ VARJÚ 1908, 18-19. The French nature of the structure was refuted by Kilián Szigeti. who pointed out that liturgical books comprising several volumes tended to be divided at Easter (SZIGETI 1963, 328).

${ }^{7}$ VARJÚ 1908, 19-20. Varjú erroneously names King Louis XI (1423-1483), who was no longer alive in 1487, at which time the throne was occupied by Charles VIII (14701498, reign: 1483-1498).

${ }^{8}$ Berkovits 1945; Berkovits 1962, 66-71; Soltész 1968 334-339; RADOCSAY-SOLTÉSZ 1969, 25-27, 65-66.

${ }^{9}$ Hevesy 1923, 32; Porcher 1964, 124.

10 Hoffmann 1929, 86: Hoffmann 1933, 297: Hermany 1933, 117-118.

11 SZIGETI 1963, 328-329; SZIGETI 1969, 272-273.

12 SzigETI 1963, 330-332: SZIGETI 1969, 268-271.

13 BALOGH 1975, 235.

14 SieVEKING 1986, 142

15 VERSPOHL 2000, 158, 160, 170-174.

${ }^{16}$ MADAs 2009, 66: TöröK 2008, 426.

17 TÖRÖK 1992, 367; TÖRÖK 2008, 428. Although the thesis approaches the issue mainly from the aspect of style, it is worth noting that the iconography of the miniatures in the Gradual also suggests that they were not copies. Its pictorial cycle as a whole and the iconography of several miniatures (e.g. fols. 37r, 41r, 45r, 184r, 188v) is completely unique among the Netherlandish artefacts that I know of. This argument is put forward by RADOCSAY-SOLTÉSZ 1969, 27.

18 This possibility was already raised by Csaba Csapodi: CsAPODI 1981, 255; CsAPODI - CsAPODINÉ GÁRDONYI 1976, 22

${ }^{19}$ Soltész 1982, 40-41, 45. Psalter of Jeanne de Laval: Poitiers, Bibliothèque municipale, ms. 41, Resurrection: fol 18r; reproduced in: Getty Images, URL: http://www.gettyimages.com/detail/illustration/the-resurrection-miniature-frombook-of-prayers-by-stock-graphic/142456311 [last retrieved: 10. 10. 2016 .

${ }^{20}$ CSAPODI 1981, 255.

21 CSEIDY 1994, 28-29. Bible reference no.: ÖNB Cod. $2771-2772$

${ }^{22}$ Hans Memling: The Last Judgment, Gdańsk, Muzeum Narodowe, inv. no. SD/413/M: Book of Hours, Bruges, c. 1470. New York, PML H.7: Book of Hours, Cambrai or Tournai, 1470-1480, Berlin, Staatsbibliothek zu Berlin, Germ. oct. 270. Further examples of this iconographic type in the Southern Netherlands: Lieven van den Clite (Ghent, 1375-c.
1422): Beaune Altarpiece, Musée de l'Hôtel-Dieu, Beaune. For its development see: KEMPERDICK 1993, 71-72, 80; BROEKHUIJSEN 2009, 54-55.

${ }^{23} \mathrm{cf}$. Bodl. Auct D inf. 2. 13, fols. 62v, 209v (for reproductions, see: LUNA URL http://bodley30.bodley.ox.ac.uk:8180/ luna/servlet/view/search/what/MS.\%20Auct.\%20D.\%20inf.\%20 2.\%2013? q =Auct $\% 20 \mathrm{D} \% 20 \mathrm{inf} \% 202 . \% 2013$ [last retrieved: 21. 10. 2016]); ÖNB Cod. 2771, fols. 77r, 129v, 176v (reproduced in: PäCHT-JENNI 1975. figs. 80-261). The latter was decorated by five hands in addition to the Master of Evert van Zoudenbalch (PÄCHT-JENn 1975, 47-49). Of these, Csejdy considers hand " $\mathrm{C}$ " to be similar to that of the Master of the Gradual: CSEJDY 1994.

${ }^{24}$ Hindman 1997, 77-83.

${ }^{25}$ Christ's Entry into Jerusalem (Met. Robert Lehman Collection, 1975.I.2471): Christ at the House of Zacchaeus Marmottan No. 187); The Martyrdom of Saint Quentin (Catalogue Sammlung Freiherr von Lanna, lot 33, present location unknown).

${ }^{26}$ For the digitalised manuscript, see: Beinecke Digital Collections URL: <http://brbl-dl.library.yale.edu/vufind/Record/3436777> [last retrieved: 21. 10. 2016 ]

The manuscript is digitalised upto fol. 110r: Archivio di Stato di Torino URL: <http://archiviodistatotorino.beniculturali.it/work/visvol_bibl.php?uid=300030\&ind $\mathrm{x}=0 \&$ rife $=>$ [last retrieved: 21. 10. 2016 ].

${ }^{28}$ SHaIlor 1984, 178; Komada 2000, 105-107.

29 The above conventional name for the master of the manuscript of the Turin Cité de Dieu, as an illuminator working in the broader circle surrounding Willem Vrelant, was first given by Friedrich Winkler: WINKLER 1925, 86. Apart from the Turin manuscript, Winkler also attributed an Histoire de la Toison d'Or to the same master (ÖS OGV ms. 2). The latter manuscript, however, is attributed by the latest research to the Master of the Vienna and Copenhagen Golden Fleece: Hans-Collas-Schandel 2009, 157: Catalogue Brussels-Paris 2011, 378. The relationship between these two illustrators will be discussed again later. The group of manuscripts compiled by Hindman are listed under the name of the Master of the Turin Augustine in the internet database created by Hanno Wijsman, which covers all illustrated manuscripts made in the Netherlands between 1400 and 1550: Luxury Bound URI $<$ http://www.cn-telma.fr/luxury-bound/index/ > [last retrieved: 10. 10. 2016]. (Some of the attributions that have appeared in the literature, but which have been called into doubt, are indicated with a question mark.) Wijsman (following Sandra Hindman, and Otto Pächt and Dagmar Thoss) links the group stylistically to Loyset Liédet: WIJSMAN 2010, 65.

${ }^{30}$ Beinecke 129, vol. 2, fol. 84 r vs. OSZK Cod. lat. 424 fols. 30r, 72r.

Komada 2000, 107. cf. BNU L I 6, fols. 44v, 98v, 189r, 239r, 293v, 359r, 429r; AST Jb. III. 12, fols. 43r, 86r, 128v. 174r, 292v and Beinecke 129, vol. 1, fols. 4v, 5r, 6v, 10r, 8v.

${ }^{32}$ The borders of BL Roval $15 \mathrm{E}$ IV. for example, in which the miniatures were painted by the Master of Wavrin, are attributed to the Master of the Vienna and Copenhagen Golden Fleece, as are the marginal decorations in a Chroniques de Froissart of Berlin Staatsbibliothek zu Berlin, Preußischer Kulturbesitz, Breslau 1), some of whose illustrations were produced by Liéven van Lathem: Catalogue Brussels-Paris 2011. 380. The eponymous work of the Master of the Dresden Praver Book (Dresden. Sächische Landesbibliothek. ms. A.311) also contained borders produced by a different illustrator: BRINKMANN 1997, 39

${ }^{33}$ Berkovits 1945, 34-35; Soltész 1982, 43-44. Gyöngyi Török also implies a larger workshop: TöRÖK 2008, 428.

34 SHAILOR 1984. 174

35 Komada 2000, 108.

36 RadocsaY-Soltész 1969, 65; CsAPODI 1976, 44; ZsuPÁN 2014A, 282. Árpád Mikó proposes a date around the end of the 1470s or 1480: MiKó 2010, 266. 
${ }^{37}$ LABORDE $1909,372$.

${ }^{38}$ Komada 2000, 95-96.

${ }^{39}$ Komada 2000, 104.

${ }^{40}$ Independently of Hindman, James Marrow stated in his private correspondence that the Master of the Turin Augustine, or a pupil of his, worked on the Budapest choir book: KOMADA 2000, 128.

${ }^{41}$ Hindman 1997, 77, 82.

42 The average size of the initials in the Gradual is $15.5 \times 16.5 \mathrm{~cm}$, while the miniatures in the New York leaf measure on average $15.6 \times 12.4 \mathrm{~cm}$.

${ }^{43}$ Hindman 1997. 81.

${ }^{44}$ The internet database Luxury Bound, based on Hindman, classified the New York leaf under the name of the Master of the Turin Augustine (URL <http://www.cn-telma fr/luxury-bound/index/> [last retrieved: 10. 10. 2016]). Apart from this, to the best of my knowledge, the literature has not otherwise reflected on its attribution.

${ }^{45}$ Reproduced in Hindman 1997, 80, fig. 10.2.

${ }^{46}$ Hindman 1997. 80

${ }^{47}$ Catalogue Freiherr von Lanna 1911, 33.

${ }^{48}$ Hindman 1997. 81

${ }^{49}$ Clark 2000, 41

${ }^{50}$ Boccaccio: Cas des nobles hommes et femmes, Hunt. HM 937: reproduced in Digital Scriptorium Database URL http://dpg. lib.berkeley.edu/webdb/dsheh/heh_brf?CallNumber=HM+937 [last retrieved: 21. 10. 2016].

${ }^{51}$ Glasgow, University Library, Hunter 60; reproduced in CARDON 1996, 289, fig. 151.

52 Komada 2000, 127. The San Marino manuscript was copied in 1462 by Haquinet le Pesquinier, while the Glasgow manuscript, based on its colophon, can be dated to 1455: CARDON 1996, 284-285. Bert Cardon attributed the dedicatory miniatures of both manuscripts to an illuminator working in direct proximity to Willem Vrelant: CARDON 1996, 284-285. Cardon also attributed a volume of Du régiment des princes (Rennes, Bibliothèque Municipale, ms. 153 to the same master, although this work has been reclassified by recent researchers as part of the ouvre of the Master of the Vienna and Copenhagen Golden Fleece: Catalogue BrusselsParis 2011, 380.

${ }^{53}$ KB 133 A 3 I-II, fol. 1r; Catalogue London - Los Angeles 2003, 278 (MCKENDRICK, Scot).

${ }^{54}$ The miniature before fol. 52r, representing the Annunciation to the Sepherds, has been cut and now bound in BL Stowe 1061, fol. 113

${ }^{55}$ O'CONOR 1818-1819, II, 3-4; Catalogue of the Stowe Manuscripts 189.5-1896, Vol. 1. no. 27: British Library, Catalogue of Illuminated Manuscripts: URL: <http://www.bl.uk/ catalogues/illuminatedmanuscripts/record.asp? MSID =1324 $\&$ CollID $=21 \&$ NStart $=27>$ last retrieved: 10.10 .2016 .

${ }^{56}$ OSZK Cod. Lat. 424. fols. 64r, 123v; Stowe 27 fols. $17 \mathrm{r}$ $66 r_{2} 75 r$.

57 The relevance of this detail from a stylistic analysis point of view comes from the fact that other illustrators frequently drew such iron ties in completely different, and sometimes quite individual ways. The Master of the Vienna and Copenhagen Golden Fleece, for example, drew long, thin blocks sealed on all four sides (BL Royal 14 E IV, fol. 259; Darmstadt, Universitäts- und Landesbibliothek, ms. 133, fol. 1r), while the Master of Edward IV used shorter, more irregular blocks, drawn with greater dynamism (BL Royal 14 E I fol. 133r, Roval 15 D I, fol. 346). The solution employed by the Master of Antoine Rolin (long, straight, thin lines, with short, thicker marks at both ends, Bodl. Douce 205, fol. 9r; BnF fr. 12550 , fol. $8 \mathrm{v}$ ) is similar to the method used by the Master of the Turin Augustine.

${ }^{58}$ For a detailed summary of the history of research into how work was organised in Netherlandish book illustration, see: GIL 2014.

${ }^{59}$ AleXaNDER 1992, 127; ALEXaNder 2011, 274.
${ }^{60}$ GLL 2014, 124-125.

${ }^{61}$ VANWIJNSBERGHE 2001.
${ }^{62}$ VANWIJNSBERGHE 2001, 120-123.

63 VANWIJNSBERGHE 2001, 132, 148.

${ }^{64}$ VANWIJNSBERGHE 2001, 142-143.

${ }^{65}$ Guillaume Godefroy took on Jean Daniel and Gilles de Vernuyt as apprentices in 1488. After two years, in 1490, the master immediately took on a new apprentice, Jean Tetrier. In 1499, Nicolas de la Forge and Nicolas Valenchon joined the workshop of Henri Van Balle within a month (VANwIJNsBERGHE 2001. 132.)

${ }^{66}$ VANIWIJNBBERGHE 2001, 149

${ }^{67}$ My thanks to Gábor Endrődi for enlightening me on this. 241.

Van Buren 1999, 20-26; Catalogue Brussels-Paris 2011,

69 AleXander 1992. 129: AleXANDER 2011, 290.

${ }^{70}$ Hindman 1997, 81. Having Antoine de Bourgogne as the commissioner is not necessarily a guarantee that the work was made in Bruges. Two masters from Lille also worked for him: the Master of the Vienna and Copenhagen Golden Fleece and the Master of the Grisailles Fleurdelisées (Catalogue Brussels-Paris 2011, 372, 378). Another illustrator from Lille, the Master of the Champion des Dames, decorated a book for Antoine de Bourgogne's wife, Jeanne de la Viefville (Paris, Arsenal 5126).

${ }^{71}$ Komada 2000, 110.

72 Catalogue London - Los Angeles 2003, 278; KomadA $2000,97$.

${ }^{3}$ GIL 2008, 181. The hand of the Master of the Vienna and Copenhagen Golden Fleece, localised in Lille, can be recognised in Le livre du Trésor (BnF fr. 191) copied by Jean du Quesne, while another copy of the same work (SaintQuentin, Bibliothèque municipale, ms. 109) and a manuscript about the deeds of Alexander the Great (BL Royal 17 F I) can be attributed to an illustrator from Tournai, the Master of the Tournai Evangeliary. The latter's works were first collated by Akiko Komada under the name of the Master of Brunetto Latini, who was localised to Tournai (KOMADA 2000, 132); a vear later, two pages from the same Evangeliary (FLP Lewis E M 42.24 and 42.25) were used to reconstruct the illuminator's ouvre by James H. Marrow who also localised his operations to Tournai (MARROW 2001. 137-140). The conventional name in use today was given after the Philadelphia leaf.

${ }^{74}$ Komada 2000. 93. 96; reproduced in Initiale: catalogue de manuscrits enluminés URL http:/initiale.irht.cnrs.fr/ ouvrages/ouvrages.php? $\mathrm{id}=6738 \&$ indexCourant $=0$ [last retrieved: 21. 10. 2016].

5 Komada 2000, 100-102.

76 KOMADA 2000, 103.

77 Komada 2000, 104.

78 LABORDE 1909, 383. Some miniatures from KBR 9005 and 9006 are reproduced in LABORDE 1909, pls. XXIII b. XXIVb, XXV b, XXVI b, XXVII b.

${ }^{9}$ Between 1435 and 1459, the governor was Baudouin d'Oignies, who, as the son-in-law of Gui Guilbaut, must have inherited the manuscript from him (Librairie des ducs de Bourgogne 2000, 58 [SOMERS, Sophie]). According to Hanno Wijsman, this manuscript, together with some other books, was acquired by Philip the Good from him (WIJSMAN 2010, 186). The source text, however, also leaves open the possibility that the manuscript only came into the Duke's possession later, from Baudouin's son, Antoine d'Oignies, who also served as governor of Lille from 1465 (Librairie des ducs de Bourgogne 2000, 58 [SOMERs. Sophie]). If the latter is the case, then the manuscript could easily have been in Lille when the Turin Cité de Dieu was made. It is also conceivable that the book staved in Lille even after the change of ownership. The inventory of 1469, compiled after the death of Philip the Good in 1467, records all the books belonging to the Dukes of Burgundy, without grouping them according to location or sub-collection (WIJSMAN 2010, 215, 246). This makes it impossible to conclude whether or not the manuscript remained in Lille, and if not, where it might have been taken when it 
was owned by Philip the Good. In February 1469, part of the library was verifiably in the residence in Lille, as evidenced by a receipt for firewood, purchased to heat the room made available to David Aubert and his associates, where they went about compiling the inventory (DOUTREPONT 1909, xxxix-xl: WIJSMAN 2010, 148).

${ }^{80}$ Librairie des ducs de Bourgogne 2000, 69, ms. 90059006 (SOMERS, Sophie).

${ }^{81}$ Reproduced in LABORDE 1909. pl. XXXII.

${ }^{2}$ Vanwijnsberghe 2001, 40; Catalogue Brussels-Paris 2011, 171-172.

${ }^{83}$ Vaniwijnsberghe 2001, 39; Librairie des ducs de Bourgogne 2000, 84, ms. 9016 (SOMERs, Sophie). - Other works have been identified linking the master of Bruges who was influenced by Van Eyck to the area around Tournai: CLARK 2000, 122

${ }^{84}$ BL Royal 14 D I, reproduced in British Library, Catalogue of Illuminated Manuscripts URL: http://www.bl.uk/ catalogues/illuminatedmanuscripts/record.asp?MSID $=836$ $2 \&$ CollID=16\&.NStart=140401 [last retrieved: 21.10 .2016 ] Only the first two miniatures can be attributed to the Master of the Golden Fleece. The coat of arms on the frontispiece of the manuscript has been identified by Laborde as that of the Dukes of Guelders. At the time the manuscript was produced around 1465-1470, the title was held by Arnold (1410-1473) and his son Adolf van Egmond (1438-1477): Arnold held the title from 1423 to 1465 , when it was taken over by Adolf for six years, before it was returned to Arnold, who ceded contro of the Duchy to Charles the Bold (1433-1477). The same coat of arms also appears in another manuscript by the Master of the Golden Fleece, in the background of the feast of John of Gaunt, Duke of Lancaster and the King of Portugal (Jean de Wavrin: Recueil des croniques d'Engleterre, BL Royal $14 \mathrm{~F}$ IV, fol. 244v). This manuscript was completed for Edward IV King of England, in 1479-1480 by the Master of the White Inscriptions and the Master of Edward IV, although it was originally commissioned by someone else from the Master of the Golden Fleece, around 1470 (DOYLE-LOWDEN-MCKENDRICK 2011, 197 [McKENDRICK, Scot]). The miniature in question comes from this initial stage of decoration. If the assumption is correct that the coat of arms is a reference to the origina commissioner, then it is probably the same as the owner of the London Cité de Dieu, who, if we accept Laborde's identification. must have been either Adolf or Arnold van Egmond This would imply that the Master of the Golden Fleece began to illuminate two manuscripts for the same family at almos the same time, both of which were completed by others. The work may have been interrupted as a result of the politica and family conflicts between the Egmond father and son in the mid-1460s and around 1470 (see WIJSMAN 2010, 342). It is possible that Edward IV also purchased the Cité de Dieu, because this manuscript was also in the English Royal Library by 1535 (DOYLE-LOWDEN-MCKENDRICK 2011, 197 [MCKENDRICK, Scot]).

${ }^{85}$ Hans-Collas-Schandel 2009. 157: Catalogue BrusselsParis 2011, 378-381.

${ }^{86}$ According to Laborde, the dragon symbolises renewal (LABORDE 1909. 385).

${ }^{87}$ Sam Fogg Hours, private collection, fol. 75v (reproduced in CLARK 2006. 157, fig. 2). The iconographic type, incidentally, is not at all the invention of the Master of the Ghent Privileges: it already appeared in the Très belles heures of Jean de Berry (Met. Cloister Collection, 1954). The next example that is closest in time and space to Stowe 27 can be found in the San Marino book of hours by Simon Marmion, who, with the diagonally placed donkey, creates a more complex system of spatiality in the scene (Hunt. HM 1173, fol. 56r).

${ }^{8}$ Sam Fogg Hours, private collection, fol. 101r (reproduced in CLARK 2006, 157, fig. 3); Warsaw, Biblioteka Narodowa, ms. II 8005, fol. 67v (reproduced in CLARK 2000, 396 fig. 75 )

${ }^{3}$ BNU L I 6, fol. 319r; AST Jb. III. 12, fols. 1r, 208r. Ko MADA 2000, 107-108.
${ }^{90}$ Valerius Maximus: Faits et dits mémorables, BnF fr. 6185 fol. 1r: Christ at the House of Zacchaeus, Marmottan No. 187 Gradual of Jacob van Brussel. Ghent. Universiteitsbibliotheek, ms. 14, vol. 1, fol. 1r.

91 CLARK 2000, 84, fig. 43.

92 HindDMAN 1997, 81

93 Komada 2000, 107-108

${ }^{94}$ Van Buren 1985, 328; Clark 2000, 130-142.

95 Copenhagen, Kongelige Bibliotek, ms. Thott 465 fol: ÖS OGV ms. 2 (reproduced in Catalogue Brussels-Paris 2011, 379, ill. 280); Dijon, Bibliothèque Municipale, ms. 2948; Épinal. Musée de l'imagerie No. 343, 344: Catalogue Brussels 1996. 134 (Thoss. Dagmar): Pächt-Thoss 1990, 107.

${ }^{96}$ Bodl. Laud. Misc. 653 fols. 1r, 3r, 5r, 15 r (reproduced in LUNAURL http://bodlev30.bodlev.ox.ac.uk:8180/luna/servlet/ view/all/what/MS.\%20Laud $\% 20$ Misc. $\% 20653$ ? sort=Shelfmark [last retrieved: 21. 10. 2016]. The hand of the Master of the Golden Fleece was recognised in the manuscript in 2009 (HANs-Collas-Schadel 2009. 157), but the leaves he painted are not specified precisely anywhere in the literature. The miniatures on fols. 7r, $13 \mathrm{r}$ and $19 \mathrm{r}$ were painted by the Rambures Master (GIL 1999, 996: GIL 2008, 170-171), while the illuminator of fols. 9r, 11r and 17r has a style that is close to that of the Master of the Tournai Evangeliary, who was based in Tournai (KomADA 2000, 122). The similarity between the Oxford leaf and the Master of the Turin Augustine was also noted by Akiko Komada: Komada 2000, 121.

${ }^{97}$ Komada 2000, 112-129, 132.

98 Komada 2000, 130-131.

99 Reproduced in Koninklijke Bibliotheek, Medieval Illuminated Manuscripts URL: http://manuscripts.kb.nl/show/images text/71+A+14 [last retrieved: 21. 10. 2016].

${ }^{100}$ Reproduced in Radocsay-SOLtész 1969, pls. XXXIII XXXIV: and in BnF, Banque d'images URL: http://images. bnf.fr/isp/index.jsp?destination=afficherListeCliches.jsp\&ori gine $=$ rechercherListeCliches.jsp\&contexte $=$ resultatRecherch eAvancee [last retrieved: 21. 10. 2016].

101 Komada $2000,128$.

${ }^{102}$ Komada must have been aware of the 1986 publication, but I could not find any reference of hers to it.

103 SIEVEKING 1986, 142

104 This is why the date of after 1485, put forward by Alois Haidinger, is not conclusively proven (HAIDINGER 1998, 70)

105 VERSPOHL 2000, 174

106 OSZK Cod. lat. fols. 22r, 37r, 79v, 197r.

107 cf. BL Royal 14 E IV, fol. 71r.

108 "annehernd deckungsgleich": VERSPOHL 2000, 174.

109 Katalog Klosterneuburg 1985, 246: HAIDINGER 1998. 70.

${ }^{110}$ BAV Ross. VII 232 and ÖNB Ink. 26 E 18. TIETZE 1911 146; Hermann 1932, 171-173. Hermann attributes the Vatican and Vienna frontispieces to the same hand.

${ }^{111}$ I am indebted to Gábor Endrődi for drawing my attention to this. The two-headed eagle on the shield of the coat of arms and on the mantle of the Margrave is also mentioned in the catalogue of the exhibition entitled Der Heilige Leopold, although it is not queried: Catalogue Klosterneuburg 1985, 246

${ }^{112}$ Csapod 1981, 255. In Cisapodi's view this is an argu ment against the Gradual having been made in Buda, for such a mistake would not have been committed in Buda. Similar heraldic mistakes were committed by Francesco Rosselli, who, in the unified coat of arms of Hungary and Aragon in Beatrice's illuminated manuscript, painted the lion of Beszterce instead of the Czech lion (ÖNB Cod. 44, fol. 1r; BEU Cod. lat. 458, fol. 1r; HAB Cod. Guelf. 39. Aug $4^{\circ}$, fol. 13r) and in the coat of arms of King Matthias, painted the Czech lion, on several occasions, with just one tail (HAB Cod. Guelf. 12 Aug. 4․ fol. 1r; Cod. Guelf. 73. Aug. $2^{\circ}$, fols. 1v, 2r).

113 TÖRÖK 1992, 367: TÖRÖK 2008, 428.

114 Berkovits 1945, 34-35; SOLTÉSz 1982, 43-44; TöröK 2008, 428. The large number of miniatures is not a factor which in itself implies that the work was shared. The Master of the Vienna and Copenhagen Golden Fleece painted 30 miniatures in a volume of the Chronique d'Angleterre (BI 
Royal 14 E 4), Liéven van Lathem and Jean le Tavernier each produced almost 60 illustrations in volumes of the Miracles de Notre Dame (Bnf fr 9198 and 9199). While it is true that the latter were made using a grisaille technique, their degree of intricacy means that producing them would have been just as time-consuming, so they do not necessarily belong in a separate category from the coloured miniatures.

${ }^{15}$ AleXANDER 2011, 290. Edina Zsupán makes a similar aroument in connection with the Florentine Francesco Rosselli, regarding it unlikely that he would have been accompanied by the Master of the Medici Iliad, who allegedly collaborated with him on several works, and whose style was also very close: ZSUPÁN 2010, 247.

${ }^{116}$ HofFMANN $1929,90$.

117 Berkovits $194.5,3.5$

118 SOLTÉSZ 1982, 44. The fluctuation in quality was already analysed in a similar way by Elemér Varjú: VARJÚ 1908, 19.

119 SZIGETI 1963, 329; SZIGETI 1969, 272-273.

${ }^{120}$ For a detailed description of the rotunda script, see: DEROLEZ 2003, 102-111.

${ }^{121}$ LiefTiNCK 1954, 32-34; Derolez 2003, 21.

122 BischOFF 1990, 131

123 Derolez 2003, 117

${ }^{124}$ London. Victoria and Albert Museum, Salting 1221: Naples, Biblioteca Nazionale, ms. I. B. 51; Poitiers, Bibliothèque Municipale, ms, 57/269; BAV Ross. 62

${ }^{125}$ FLP Lewis E 106; ÖNB 13243.

${ }^{126}$ Getty Ludwig IX 19; Rouen. Bibliothèque Municipale. ms. 3028.

${ }^{127}$ Derolez 2003, 117-118. The Grimani Breviary, for example, was made for Antonio Siciliano (Venice, Biblioteca Nazionale Marciana, ms. lat. I 99); the breviary Add. 18851 in the British Library was made for Isabella of Castile, probably as a gift from Francisco de Rojas; the Mayer van den Bergh Breviary was made for a Portuguese client (Antwerp, Museum Mayer van den Bergh, inv. 946); and the Borgia Book of Hours in Brussels was made for Pope Alexander VI KBR IV 480).

Derolez 2003, 118. In the view of Johan P. Gumbert even if certain Flemish scriptors committed mistakes in their use of Italian rotunda, others wrote in a way that was indistinguishable from that of an original Italian scribe (GUMBERT 2008, 210, 213). Gumbert's argument, however, pertains to a later period than when the Gradual was made, to the early sixteenth century, when this Italian script had become fashionable in books of hours produced in Ghent and Bruges.

129 TOURNOY 2006, 269-272. Geirnaert assumes that there was an entire "Italian scriptorium" in Bruges, with several distinguishable hands, behind the copying of this group of manuscripts (GEIRNAERT 1992, 175, 177). Francesco Florio's Virgil manuscript now in Holkham Hall (ms. 311) also used the rotunda script

${ }_{131}^{130}$ GEIRNAERT 1992, 173-181

131 Out of eight sixteenth-century choir books in the catalogue to the exhibition entitled Flemish Illuminated Manuscripts, seven were copied by clerics (Catalogue Brussels - Florence - Saint Petersburg 1996, 166, 170, 172, 174, 178, 188). The eighth was copied by Francis Weert of Leuven, whose known works were all written in northern textualis, and were all made for abbeys or for the personal use of abbots. The conservatism of the script and the circle of the commissioner of such liturgical books are also mentioned by Richard Gay in his brief biography of Weert: GAY 2006, 186.

132 Kálmáncsehi Breviary: OSZK Cod Lat 446; Pontifica of Bishop Filipec: Esztergom, Érseki Simor Könyvtár 2-364/7864; Vatican Missal: BAV Urb. Lat. 110; Buda Antiphonary: Bratislava, Archiv Mesta EC Lad.6. OSZK A 23/III and V: Franciscan Gradual of Lippa: Alba Iulia, Biblioteca Documentară Batthyáneum, Mss. I. 2.

${ }^{133}$ Brussels Missal. KBR 9008. SzIGETI 1963, 329-330. SZIGETI 1969, 272

${ }^{134}$ De La MARE 1985, 474, 513: in addition to King Matthias, he also worked for the Medicis (Florence, Biblioteca
Laurenziana, Plut. 16, 18) and for the Neapolitan Court (Valencia, Universitat de Valencia, ms. 851).

35 Gradual of Lippa: see note 132; Franciscan Antiphonary: Güssing, Bibliothek des Franziskanerklosters, 4/1; Diurnal: Sighişoara, Lutheran Rectory, s. n.

136 SZENDREI 1985, 71-72

137 Bakócz Gradual: Esztergom, Főszékesegyházi Könyvtár, ms. I 1b; Zalka Antiphonary: Győr, Székesegyházi Kincstár és Könvvtár s. n.: Gradual of King Vladislav: Esztergom, Főszékesegyházi Könyvtár, ms. I. 3; Antiphonary of Osvát Thuz: Zagreb, Nacionalna i sveučilišna knjižnica, M. R. 10.

138 SZIGETI 1963, 329; SZIGETI 1969, 272-273.

139 SZENDREI 1981, 43.

${ }^{140}$ Lodi, Biblioteca Comunale Laudense, Antifonario Laud. 1-5, Breviario Pallavicino; PML M.682-M.687.

${ }^{141}$ Marubbi 1998. 16: Marubbi 2003, 93.

142 PML M.683, M.685; MARUBBI 1998, 16; Corsair, The Online Research Resource of the Pierpont Morgan Library, Manuscript Descriptions, URL: <http://corsair.morganlibrary.org/ msdescr/BBM0683a.pdf $>$ [last retrieved: 10. 10. 2016]

${ }_{143}$ LONGHI 1998, 141, 144.

${ }^{144}$ e.g.: OSZK Cod. lat. 424. fols. 10r, 17v, and 176r; PML M.686, fols. 64v, 128r, and 179r.

145 Cremona, Museo Civico, cod. XVI.

146 ZANONI 1955, xxxiii: Zanoni - erroneously - attributed the illustrations to Apollonio as well. In his paper of 1992 Mario Marubbi identified the illustrator as Giovan Pietro da Cemmo (Marubbi 1992, 17-23).

${ }^{147}$ Christie's, London. 18 June 2013, lot 8: FLP Lewis E M 070.04 .

${ }^{148}$ Florence, Museo dell'Opera del Duomo, Antifonarium B, fol. 7r.

${ }^{149}$ OSZK Cod. lat. 424, fols. 33v, 17v; PML M.686, fols. 64v and 128 .

150 OSZK Cod. lat. 424, fol. 10r: PML M.686, fol. 179r.

151 OSZK Cod. lat 424 fols. $2 \mathrm{v}$ and $17 \mathrm{v}$; PML M.866 fol. 179r, M.867, fol. $10 \mathrm{v}$.

152 Florence, Museo dell' Opera del Duomo, Corale S, fol. $5 v$.

153 Graduale 1, fol. 60r, private collection; Antiphonarium. Boston Public Library, Med. 120, fol. 1r. Reproduced in: Catalogue Bologna 2012, 52: Novasconi 1976, 291.

154 See the codicological description in the appendix.

155 Catalogue Budapest 2008, 258, No. 5.5. (Pócs, Dániel).

156 VARJÚ 1908, 8-9, 18

157 OSZK Cod Lat 446.

158 BaLOGH 1927, 1-2; FARBAKY 2013, 48.

159 CsaPODI 1981, 20; MARuBbi 2003, 98-99. Péter Farbaky also draws attention to the importance of the documents: FARBAKY 2013, 50

${ }^{160}$ Berkovits 1959, 255-256. The author maintains this identification in her work of 1962: BERKOVITS 1962, 66.

161 MarubBi 2003, 96

162 Marubis 2003, 96; WeHLi 2003, 84.

163 HAB Cod. Guelf. 39 Aug. 4 : MiKó 2010, 265-266.

164 Мiкó 2010, 262, 265.

165 ALEXANDER 2011, 290

166 For details, see: ZSUPÁN 2010; ZSUPÁN 2014B

167 DE la MARE 1985, 462, 503

168 Aristeas: Ad Philocratem, BSB clm. 627; Plato: Epistolae, Madrid, El Escorial, Real Biblioteca, g. III. 3.

169 Csapodi 1981, 14; De la Mare 1985, 462: Zsupán 2013 170. Edina Zsupán established that both works "belonged to the basic repertoire of Gundisalvus" (ZSUPÁN 2010, 244; for the related manuscripts, see: DE LA MARE 1985, 503). Aristeas: Ad Philocratem and Plato: Epistolae, Bologna, Biblioteca Universitaria ms. 1797; Plato: Epistolae, together with letters by other Greek philosophers. Florence, Biblioteca Riccardiana 128; Harvard Coll. Typ. 178.) All three manuscripts were illuminated in Florence, and what is more, Francesco Rosselli himself worked on the copy which is presently in Florence. This all seems to indicate that Gundisalvus never visited Buda.

170 ZSUPÁN 2010, 247; ZSUPÁN 2013, 171 
171 ZSUPÁN 2010, 248-252.

172 ZSUPÁN 2010, 247-248.

${ }^{173}$ Fol. 76v; and, in particular, fol. $115 \mathrm{v}$.

${ }^{174}$ MiKó 2010, 266.

175 BAV Urb. lat. 110, fol. 103v: BERKovits 1945, 35.

${ }^{176}$ Marubbi 2003, 96: Wehli 2003. 84

${ }^{77}$ Erzsébet Soltész, citing Berkovits, describes the master of the scene of the The Israelites Entering the Promised Land as having studied in Milan: SoLTÉsz 1982. 17.

${ }^{8}$ Cremona, Museo Civico, cod. XVI fols. 41r, 158v, cod.

XIX fol. 3v. Reproduced in Marubbi 1992, 17, 21, 24.

${ }^{79}$ TöвÖK 2008, 428.

${ }^{180}$ FARBAKY 2013, 51-52. Ilona Berkovits was the first to posit that he had come to Hungary from Ferrara: BERKoviTs 1941, 30

181 SOLTÉsz 1982, 17.

${ }^{182} \mathrm{It}$ is definitely worth conducting further investigations into the secondary decoration of the Gradual. At present, it is only possible to note that the rest of the large initials and the small initials with filigree decoration are reminiscent of those found in Netherlandish manuscripts. Among the manuscripts made in Buda, none has yet come to light whose decoration bears such a close stylistic similarity to that in the choir book, so for now there is no evidence that the Gradual was made in Buda.

${ }^{183}$ Jewel-like decoration: Iohannes Regiomontanus: Epitome Almagesti, ÖNB Cod. lat. 44; Missale, Brussels, KBR 9008 (1487): Leon Battista Alberti: De re aedificatoria, BEU Cod. lat. 419 (1485-1490): Antonius Averulinus: De architectura libri XXV, Venice, Biblioteca Nazionale Marciana, Lat. VIII 2 (1487-1489): Flavius Philostratus: Heroica, Imagines, Vitae Sophistarum, Epistolae. OSZK Cod. lat. 427 (1487-1490): Gregorius Magnus: Dialogi de Vita et miraculis patrum Italicorum libri IV, Vita Gregorii Magni per Iohannem Diaconum, BEU Cod. lat 449 (1488-1490); Beda Venerabilis: De natura rerum, Lucius Annaeus Seneca: Questiones naturales, BSB Cod. lat. 175 (1490); Ambrosius: Sermones, Maximus Taurensis: Sermones, Homiliae, Basilius Magnus: Homiliae, Ambrosius: De poenitentia, BnF lat. 1767 (1489); Iohannes Cassianus: De institutis coenobiorum, De vita Cassiani, BnF lat 2129 (1490-1491): Aristotle: Opera cum commentarïs Averroüs. BnF Vélins 474-478 (1490-1491): Missale. BAV Urb. lat. 110 (1488-1490); Augustine: Expositio in psalmos, Stuttgart Württembergische Landesbibliothek. Cod. theol. et phil. fol 152 (1485-1490): Augustine: Epistolae, ÖNB Cod. lat. 653 (1485-1490); Priscianus Lydus: In Theophrastum interpretatio de sensu et phantasia. HAB Cod. 10. Aug. $4^{\circ}$ (1489).

${ }^{184}$ Although it is generally true that fifteenth-century Austrian manuscript painting was only negligibly influenced by Italian miniature painting, and the Renaissance style only began to be accepted in Austria somewhat later than in Hungary (RoLAND 2003, 522-523), Italianate ornamentation does appear among Viennese illuminators in the second half of the fifteenth century (SCHULLER-IUCKES 2009, 16-17, 21). In some instances, such as the book bindings of Ulrich Schreier, the influence probably came via Buda (SCHULLERJuCKEs 2009, 67-68, 139). The Master of the Wolfgang Missal also used jewel-like decoration, although not until 1499, in the Gradual of Louka (Olomouc, Vědecká knihovna, ms. IV 1, fol. $1 \mathrm{r}$ ): moreover, the influence for this also seems to have come via Buda, for the similarity to the marginal decorations in the Cassian Corvina (BnF lat. 2129) is very close (SIEVEKING 1986, 116-117, 133)

185 Since Sieveking, the supposition has often recurred that the illuminator, who had previously worked in Buda, arrived in Vienna in the company of King Matthias after the fall of the city in 1485, and that it was there he was given the commission from the monastery in Klosterneuburg (SIEVEKINC $1986,142)$. Sieveking's starting point for this was that the Master of the Gradual, who had been "trained on FrancoFlemish models," belonged to the "school of Buda," although on the basis of the cited literature this assertion is far from certain (out of BERKOVITS 1963. CSAPODI 1973 and SOLTÉsZ
1982, only Csapodi proposed it had been made in Buda). Verspohl also adopted the theory of the Master of the Gradual having travelled to Vienna in 1485, but argued that the Gradual was made in Buda; he regarded 1485 as the terminus ante quem of the Gradual's illumination (VERSPOHL 2000 , 174). Gyöngvi Török also reversed the logical sequence, and in her view, Sieveking's identification of the illustrator of the incunabulum of Klosterneuburg is evidence that the Gradual was created in Buda (ТӧвÖK 2008, 428)

${ }^{186}$ Joachim Verspohl interprets the soldiers in black armour on fol. 132r as King Matthias's black army (VERSPOHL 2000 160). despite the fact that there are warriors in similar armour in many other manuscripts from the same period which have absolutely no connection with Matthias (e.g.: KB 133 A 7 ii, fol. 293r; BL Roval 14 E 4, fol. 252r). The building visible in fol. 149r is, in his view, none other than Buda Castle (Fig. 9), even though it bears no resemblance to any of the contemporary engravings of the building (VERSPOHL 2000 174). The fountain that can be seen in the foreground of fol. 103r (Fig. 32), with the small nude statue, is adjudged to be a miniature version of the Minerva Fountain, which is only known from the written sources (VERSPOHL 2000, 170-172). This is also shared by his student, Zita Ágota Pataki (PATAKI 2005, vol. 1, 224). Apart from the risk involved in identifying this detail as the destroved work, simply on the basis of a single, brief source, the fact that the statue on the fountain in the Gradual is naked even contradicts Bonfini's description of Pallas (which Pataki also quotes) as "begirdled" "subcincta") (PATAKI 2005, vol. 2, 401). Additionally, there was a tradition in Netherlandish manuscript painting of fountains adorned with nude statues (e.g.: BnF fr. 9342 fol. 207r; Getty Ludwig XIII 6, fol. 9r: BnF fr. 331 fol. 2r). Similar scepticism is awakened when Pataki interprets certain instances of red marble - such as the stairs and balustrade in the view of the court of King David (fig. 32) - or the "majolica and marble floor tiles" as unmistakable references to the palace in Buda (Pataki 2005, vol. 1, 214-215). It is easy to find examples of such features in other works of Netherlandish miniature painting from the age, which refutes the idea that these motifs were specific to Buda (BL Royal 14 E IV, fols. 39r, 186r; red marble fountain and stairs: BL Roval 17 E IV, fols. 13r, 55r).

${ }^{187}$ Wehti 2005, 867, 874

${ }^{188}$ Perger 1982, 246

${ }^{189}$ FonTIUs 1931, 37 [II 13]. I am indebted to Dániel Pócs for drawing my attention to this letter.

${ }^{190}$ Török 1992, 366-367.

${ }^{191}$ SIEVEKING 1986, 142. Michaela Schuller-Juckes, in her dissertation on Ulrich Schreier, states that only Hand G, the maker of the penwork decorations, exhibits any Netherlandish influence: SCHULLER-JUCKES 2009, 102.

192 Johannes de Vico: Chronicon. ÖNB Cod. 325. Reproduced in: Smeyers 1999, 439; Pä́ht-Jenni 1975, 50, fig. 57; Pä́hT-JenN-Thoss 1983, 72, fig. 74. Unfortunately, the manuscript only came to my attention after this paper was submitted, so I had no chance to make a more thorough investigation.

193 In the as-vet unidentified scene in the central medallion on the right of the frontispiece of the Tolhopff Corvina, one of the kings is wearing a blue gown that also features the fleurde-lis, although the manuscript has no French connection at all (HAB Cod. Guelf. 84.1. Aug. 2 ${ }^{\circ}$. fol. 1r). I would like to thank Dániel Pócs for pointing out this detail.

${ }^{194}$ WiJSMan 2010, 43.

195 BERKOVITS 1959, 254: Soltész 1982, 18. Verspohl concluded that it was John Corvinus, the (illegitimate) son of King Matthias: Verspont 2000, 166. For the role played by Hercules as a symbol of the power of King Matthias see: Pócs 2013. There is less certainty surrounding the identity of the other child, playing on a lyre and holding a dog on a leash, although several commentators have suggested it may be Orpheus: BERKOVITS 1959, 254: SOLTÉSz 1980, 18 TöRÖK 2008, 428. The beehive in the bottom-left corner of the miniature has also been described as an emblem of King 
Matthias (Berkovits 1959, 254; Di Pietro Lombardi 2002. 119). However, the beehive may simply be a reference to the Promised Land, flowing with milk and honey, like the figure milking the goat in the background. As for the representation of power in other liturgical manuscripts of King Matthias, in the Vatican Missal, there are coats of arms in several places: BAV Urb. lat. 110, fols. 1r, 13v, 103v, 105r, 108r, and 188v; in the Brussels Missal there are portraits and coats of arms KBR 9008. fol. 8v: in the Roman Breviary, his emblems also regularly appear in the marginal decoration, alongside the coats of arms: BAV Urb. lat. 112, fols. 7v, 8r, 278v, 279r, 345v. $346 \mathrm{r}, 55.5 \mathrm{v}$, and $556 \mathrm{r}$.

196 SOLTÉsz 1982, 35-38. For the ad hoc connection, see: CSAPODI 1981, 254.

Although, the decoration of the Turin and New Haven manuscripts is, of course, quite revealing with regard to the Master of the Turin Augustine, it is important to note that both the Cité de Dieu and the Bible historiale are strongly linked to already existing iconographical cycles.

198 The missing page was first pointed out by Kilián Szigeti: SzIGETI 1963, 327. On the last page, beneath the text, the number "202" appears, written in pencil. This either was written before the page was removed, or was added by somebody who noticed the missing page.

${ }^{9}$ GentILOTTI, Giovanni Benedetto: Catalogus manuscriptorum codicum latinorum Bibliothecae Palatinae Vindobonensis. Vol. 1: Codices theologici, ÖNB Cod. Ser. n. 2207, fols 10v-11r. I am grateful to Friedrich Simader for sending me the relevant section of the manuscript catalogue.

${ }^{200} \mathrm{On}$ some pages they are visible beneath the notes that are written in paler ink (fol. 173v), while in others they are simply in a different place from where the notes were finally written. This does not imply a change in the music itself, at least not where longer sequences of scratched-out notes can be observed (e.g. fol. 170r, rows 1-2), but only that the melody was noted down one line higher or lower, following the relocation of the C-clef (fol. $169 \mathrm{v}$, rows 3 and 5 , fol. 170r, top two lines, fol. 171r, top line)

${ }^{201}$ Deciphered in: VARJú 1908, 5

202 CSAPODI 1964, 207-208; SZIGETI 1969, 271. For more about the peculiarities of the coat of arms, see the above chapter, titled The Miniature of Saint Leopold of Klosterneuburg:

${ }_{203}$ This must be after 1656 , because a similar mark also features in the volumes acquired from the Fugger Library, e.g. ÖNB Cod. 11883.

${ }^{204}$ In the catalogue by Hermann Julius Hermann. based on information provided by Ottokar Smital, it is stated that it was taken to the court library from Tübingen, and Csaba Csapodi also follows the same provenance in his book of 1973 (Hermann 1933, 117; Csapodi 1973, 420).

${ }^{205}$ Catalogus librorum Wirtenbergensium, c. 1635 (ÖNB Cod. ser n. 4450): "Missale secundum usum Ecclesiae Catholicae in chorali, manuscriptum elegantissimum, cum pulchris miniaturis ex Bibliotheca Matth. Corvini manuscript. fol. regal."; Bibliotheca Caesarea Viennensis Ferdinandi III. Romanorum Imperatoris Augustissimi (ÖNB Cod. 135.56): "Rituale et Graduale Musicum Romanum in Pergameno elegantissime scriptus cum figuris" (SCHREINER 1974, 700). 206 SCHREINER 1974, 700.

${ }^{207}$ CSAPODI 1981, 44. The name "Württembergische Landesbibliothek" may be mistaken here, because the predecessor to the present institution was not established until the second half of the eighteenth century.

208 SCHREINER 1974, 699.

209 SCHREINER 1974. 746.

210 CSAPODI 1973, 421. For more about the transfer of the treasures from the chapel of Buda Castle to Bratislava, and then to Vienna, see: LUDIKOVÁ 2005, 130-131. The inventory of 1530 is cited in: KNAUZ 1862, 10-16 (item 16). 